Andrews University

Digital Commons @ Andrews University

1981

\title{
A Study of Self-Concept of Hearing-Impaired Students as Compared to the Self-Concept of Normal-Hearing Students
}

Wayne K. Wright

Andrews University

Follow this and additional works at: https://digitalcommons.andrews.edu/dissertations

Part of the School Psychology Commons, and the Speech Pathology and Audiology Commons

\section{Recommended Citation}

Wright, Wayne K., "A Study of Self-Concept of Hearing-Impaired Students as Compared to the SelfConcept of Normal-Hearing Students" (1981). Dissertations. 1564.

https://digitalcommons.andrews.edu/dissertations/1564

https://dx.doi.org/10.32597/dissertations/1564

This Dissertation is brought to you for free and open access by the Graduate Research at Digital Commons @ Andrews University. It has been accepted for inclusion in Dissertations by an authorized administrator of Digital Commons@ Andrews University. For more information, please contact repository@andrews.edu. 


\section{Andrews \$university}

Seek Knowledge. Affirm Faith. Change the World.

Thank you for your interest in the

\section{Andrews University Digital Library of Dissertations and Theses.}

Please honor the copyright of this document by not duplicating or distributing additional copies in any form without the author's express written permission. Thanks for your cooperation. 


\section{INFORMATION TO USERS}

This was produced from a copy of a document sent to us for microfilming. While the most advanced technological means to photograph and reproduce this document have been used, the quality is heavily dependent upon the quality of the material submitted.

The following explanation of techniques is provided to help you understand markings or notations which may appear on this reproduction.

1. The sign or "target" for pages apparently lacking from the document photographed is "Missing Page(s)". If it was possible to obtain the missing page(s) or section, they are spliced into the film along with adjacent pages. This may have necessitated cutting through an image and duplicating adjacent pages to assure you of complete continuity.

2. When an image on the film is obliterated with a round black mark it is an indication that the film inspector noticed either blurred copy because of movement during exposure, or duplicate copy. Unless we meant to delete copyrighted materials that should not have been filmed, you will find a good image of the page in the adjacent frame. If copyrighted materials were deleted you will find a target note listing the pages in the adjacent frame.

3. When a map, drawing or chart, etc., is part of the material being photographed the photographer has followed a definite method in "sectioning" the material. It is customary to begin filming at the upper left hand corner of a large sheet and to continue from left to right in equal sections with small overlans. if necessary, sectioning is continued again-beginning below the first row and continuing on until complete.

4. For any illustrations that cannot be reproduced satisfactorily by xerography, photographic prints can be purchased : additional cost and tipped into your xerographic copy. Requests can be made to our Dissertations Customer Services Department.

5. Some pages in any document may have indistinct print. In all cases we have filmed the best available copy.

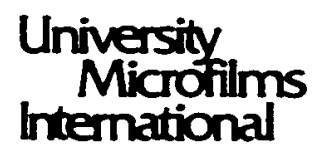

300 N. ZEEB RO. ANN AABOR. MI 48106 
Reproduced with permission of the copyright owner. Further reproduction prohibited without permission. 
Wrights Wayse $\mathbf{K}$.
A STUDY OF SEIF-CONCEPT OF HEARING-RMPAIRED STUDENTS AS
COMPARED TO THE SELF-CONCEPT OF NORMAL-HEARNNG STUDENTS

Andrews University

EDD. 1981

\section{University \\ Microfilms \\ International 300 N. Zeeb Roed, Ama Artor, Ma 48106}

\section{Copyright 1981 \\ by}

Wright, Wayne K.

All Rights Reserved 
Reproduced with permission of the copyright owner. Further reproduction prohibited without permission. 


\title{
Andrews University
}

School of Graduate Studies

\section{A STUDY OF SELF-CONCEPT OF HEARING-IMPAIRED STUDENTS AS COMPARED TO THE SELF-CONCEPT OF NORMAL-HEARING STUDENTS}

A Dissertation

Presented in Partial Fulfillment

of the Requirements for the Degree

Doctor of Education

\author{
by \\ Wayne Wright \\ Summer 1981
}




\title{
A STUDY OF SELF-CONCEPT OF HEARING-IMPAIRED STUDENTS AS COMPARED TO THE SELF-CONCEPT OF NORMAL-HEARING STUDENTS
}

\author{
A dissertation presented \\ in partial fulfillment of the requirements \\ for the degree \\ Doctor of Education
}

by

Wayne $\mathrm{K}$. Wright

APPROVAL BY THE COMMITTEE

Mereen Dran

Mergedes Dyer, Chairperson
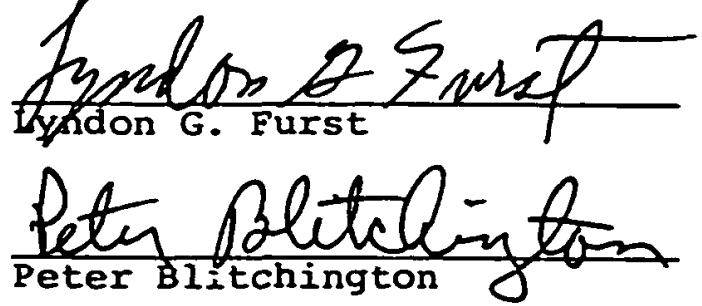

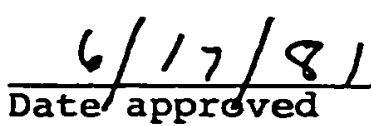

Date approved
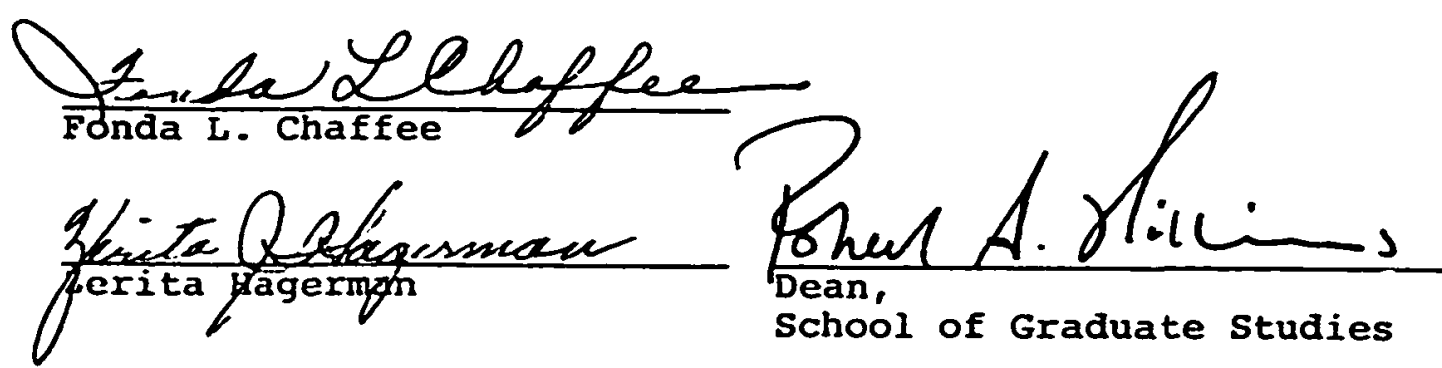


\title{
ABSTRACT
}

\section{A STUDY OF SELF-CONCEPT OF HEARING-TMPAIRED STUDENTS AS COMPARED TO THE SELF-CONCEPT OF NORMAL-HEARING STUDENTS}

\author{
by \\ Wayne $\mathrm{K}$. Wright
}

Chairperson: Mercedes Dyer 


\title{
ABSTRACT OF GRADUATE STUDENT RESEARCH DISSERTATION
}

Andrews University

Department of Education

\begin{abstract}
Title: A STUDY OF SELF-CONCEPT OF HEARING-IMPAIRED STUDENTS AS COMPARED TO THE SELF-CONCEPT OF NORMAL-HEARING STUDENTS
\end{abstract}

Name of Researcher: Wayne $\mathrm{k}$. Wright

Name and title of faculty adviser: Mercedes Dyer, Ph.D.

Date completed: June 1981

Problem

One of the important problems for the handicapped child is whether he can develop an adequate self-concept. This is a significant problem for the hearing-impaired child in a regular school setting. If the development of a self-concept is contingent upon the ability to express needs, wants, and desires, what is the self-concept of a child who cannot describe his feelings? The present study attempts to measure the self-concepts of the 
hearing-impaired students and to compare them to the selfconcepts of the hearing students.

\section{Method}

The Piers-Harris Children's Self-Concept Scale was used to evaluate the self-concepts of 926 students of the Berrien County Day Program for Hearing-Impaired and the Berrien Springs Public Schools. Sixty-nine hearingimpaired and 857 hearing students in grades six through twelve were tested. A $t$-test was used to compare the means of the hearing-impaired and the hearing for each grade, the middle school, and the high school.

\section{Results}

There were no significant differences $(p<.05)$ between the self-concept means for the hearing-impaired and the hearing students. Also, there were no significant differences $(p<.05)$ between the national norm as established by the Piers-Harris Children's Self-Concept Scale and the means for the hearing-impaired and the hearing students.

\section{Cosclusions}

The hearing and the hearing-impaired students have self-concepts that are not significantly different. These means are also not significantly different from the national norm as established by the Piers-Barris Children's Self-Concept Scale. The eighth- and ninth-grade 
hearing students tend to have a higher self-concept with regard to happiness and satisfaction. The eighth- and ninth-grade hearing-impaired students tend to have a higher self-concept with regard to physical appearance. The high school hearing students tend to have a higher self-concept with regard to happiness and satisfaction and physical appearance and attitude than the high school hearing-impaired students do.

The hearing students and the hearing-impaired students have many self-concept factors that are very similar. The range of the self-concept scores for each group of hearing-impaired and hearing students is very similar. 
TABLE OF CONTENTS

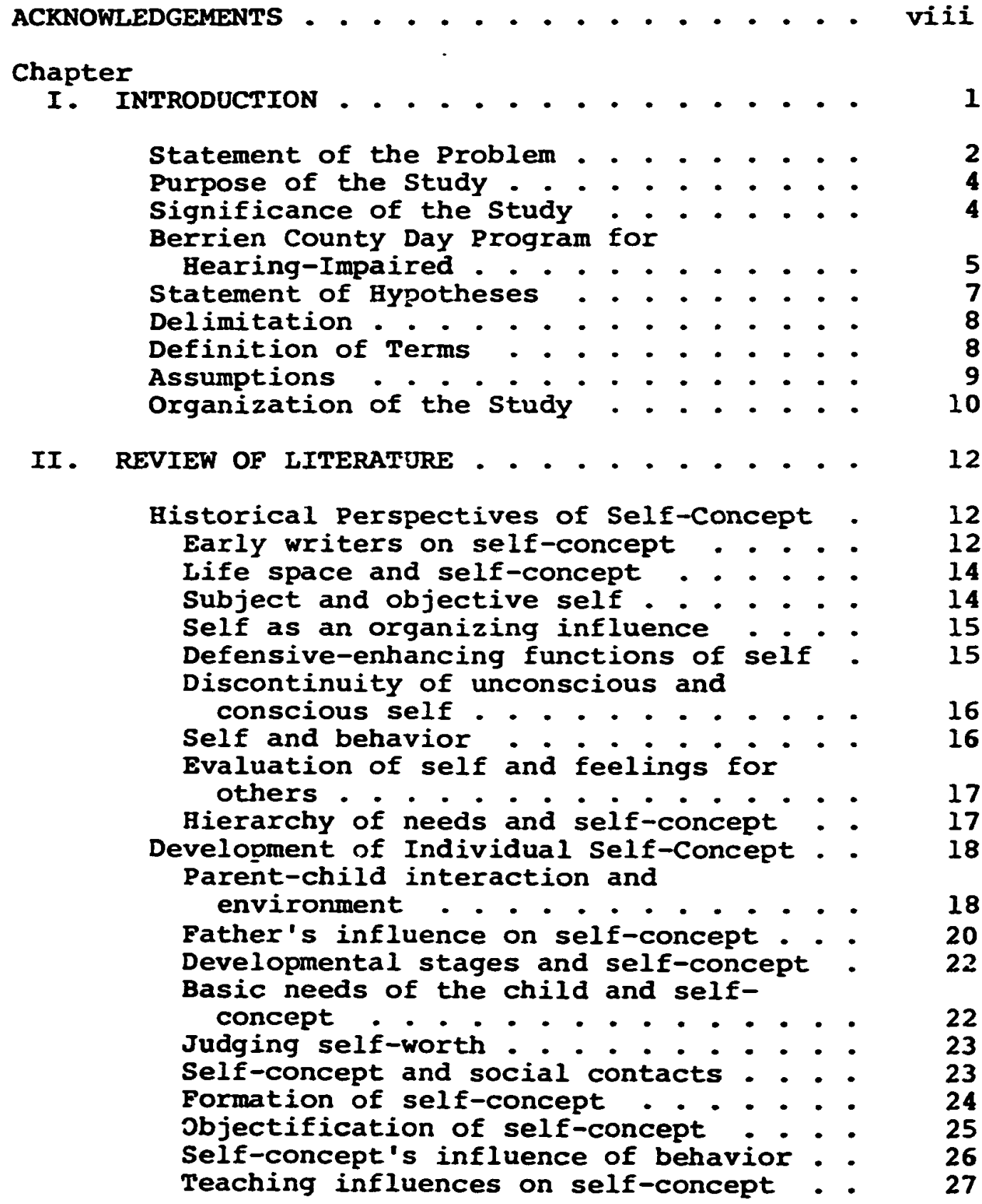


Self-concept in scholastic success . . . . 27

Self-concept during adolescence . . . . . 28

social environment and adolescent

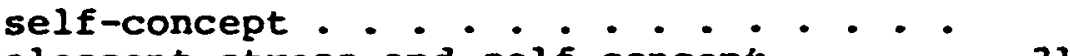

Adolescent stress and self-concept. . . . 31

Self-estimate and ego aspirations . . . . 31

Aspiration influence on self-concept . . 32

Unfinished adolescent tasks and self-

concept . . . . . . . . . . . . . . 34

Measurement of Self-concept . . . . . . 35

Types of research on self-concept . . . . 35

Definition of self . . . . . . . . . . . . 35

Limitation of self-concept measurement - - 36

Validity of self-concept research . . . - 38

Early reports of self-concept research . - 38

Two recommended self-concept scales . . . 39

Self-Concept Development of Hearing-
impaired . . . . . . . . . . . . 41

Special needs of hearing-impaired . . . . 41

Self-concept and social adjustment. . . . 42

Somatopsychology anä self-concept . . . . 43

Hearing-impaired self-concept and school - 44

Adolescent stress and hearing-impaired

self-concept... . . . . . . . . . 47

Hearing-impaired Education . . . . . . . . 48

Early beginnings .. . . . . . . . . . 48

The Bell family contribution . . . . . . 49

Oral versus silent methods... . . . . . 50

Twentieth-century advances . . . . . . . 51

Direction of hearing-impaired education . 54

Sumnary . . . . . . . . . . . . 55

III. RESEARCH DESIGN . . . . . . . . . . . . 59

Null Hypotheses ............... 60

Population for the Study . . . . . . . . 61

Instrumentation . . . . . . . . . . . . 61

Piers-Harris Children's Self-Concept Scale. 61

Development of the scale . . . . . . 62

Validity . . . . . . . . . . . . . 63

Reliability . . . . . . . . . . . . 64

Administration . . . . . . . . . . . 65

Scoring . . . . . . . . . . . . . 65

Procedure . . . . . . . . . . . . . . 65

Summary .................. . 66

IV. PRESENTATION AND ANALYSIS OF DATA ....... 68

Presentation of the Data ......... 68

Participants ................ 68

Group and grade means:. . : . : . : : 69

Comparison of grade, group, and national means . . . . . . . . . . . . 75

iv 
Testing the Hypotheses . . . . . . . . 77

Self-concept Factors . . . . . . . . . 82

V. SUMMARY, CONCLUSIONS, AND RECOMMENDATIONS • 92

Summary - . . . . . . . . . . . . . 92

Overview of related literature. . . . 93

Population . . . . . . . . . . . 96

Delimitation .. . . . . . . . . . 96

Instrumentation ............ . . 96

Results and ajiscussion . . . . . . . . 97

Conclusions . . . . . . . . . . . . . 101

Recommendations ............ 102

APPENDIX A: THE PIERS-HARRIS CHILDREN'S SELF-

APPENDIX B: TEST RESULTS OF THE PIERS-HARRIS

105

CHILDREN'S SELF-CONCEPT SCALE . . - 112

SELECTED BIBLIOGRAPHY . . . . . . . . . . . . 150

VITA .................... . . . 165 


\section{LIST OF TABLES}

1. Percentages of Middle-School Students Tested

2. Percentage of High-School Students Tested. . 71

3. Percentage of Total School Students Tested . . 71

4. Sixth Grade Means on Piers-Harris Children's Self-Concept Scale ............. . 72

5. Eighth Grade Means on Piers-Harris Children's Self-Concept Scale ............. . 72

6. Ninth Grade Means on Piers-Harris Children's Self-Concept Scale .............. 73

7. Tenth Grade Means on Piers-Harris Children's Self-Concept Scale . . . . . . . . . . 73

8. Eleventh Grade Means on Piers-Harris Children's Self-Concept Scale... . . . . . 74

9. Twelfth Grade Means on Piers-Harris Children's Self-Concept Scale . . . . . . . 74

10. Total Middle School Means on Piers-Harris Children's Self-Concept Scale . . . . . . . 75

11. Total High School Means on Piers-Harris Children's Self-Concept Scale . . . . . . . 75

12. Comparison of Grade Means and National Mean Using a t-Test . . . . . . . . . . . . 76

13. Comparison of Group Means and National Mean Using a t-Test . . . . . . . . . . . . . . 77

14. Comparison of Boys' and Girls' Means for Each Grade .. . . . . . . . . . . . . ... 78

15. Comparison of Boys' and Girls' Means for Each School .................... 78

16. Comparison of Means of Hearing-Impaired and Normal-Hearing Students . . . . . . . . 79

17. Comparison of Means of Hearing-Impaired Students and the National Mean ....... 89

18. Comparison of Means of Normal-hearing students and the National Mean . . . . . . . . . 81

19. Comparison of Factors for Sixth Grade . . . . . 82

20. Comparison of Factors for Eighth Grade . . . . 83

21. Comparison of the Discriminant Function in Eighth-Grade Hearing and Hearing-Impaired . . 84

22. Comparison of Factors for Ninth Grade . . . . . 84

23. Comparison of the Discriminant Function in the Ninth-Grade Hearing and Hearing-Impaired . . 85

24. Comparison of Factors in Tenth Grade . . . . . 86

25. Comparison of Factors in the Eleventh Grade - . 86

vi 
26. Comparison of the Factors in the Twelfth

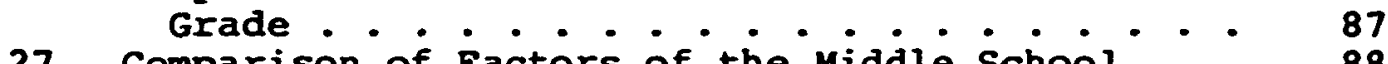

28. Comparison of Factors of the Middle School -88

28. Comparison of Discriminant Function in MiddleSchool Hearinc and Hearing-Impaired..... $\quad 89$

29. Comparison of Factors of the High School . . . 89

30. Comparison of Factors for All students . . . . 90

31. Comparison of Discriminait Function of All Students in Middle School and High School . . 91

32. Test Results of the Piers-Harris Children's Self-Concept Scale; Middle School, Grade 6 . 113

33. Test Results of the Piers-Harris Children's Self-Concept Scale, Middle School, Grade 7 . 118

31. Test Results of the Piers-Harris Children's Self-Concept Scale, Middle School, Grade 8 . 124

35. Test Results of the Piers-Harris Children's Self-Concept Scale, Hearing-Impaired . . . 129

36. Test Results of the Piers-Harris Children's Self-Concept Scale, High School, Grade 9 • . 131

37. Test Results of the Piers-Harris Children's Self-Concept Scale, High School, Grade 10 . 136

38. Test Results of the Piers-Harris Children's Self-Concept Scale, High School, Grade II . . 141

39. Test Results of the Piers-Harris Children's Self-Concept Scale, High School, Grade 12 . . 146

40. Test Results of the Piers-Harris Children's Self-Concept Scale, High School, HearingImpaired

vii 
ACXNOWLEDGEMENTS

Any student who completes a doctoral program must have a patient, understanding, knowledgeable, and encouraging chairman. For the writer, Dr. Mercedes Dyer has been all of these and more. Drs. Furst, Blitchington, and Chaffee have admirably been the supporting cast that helped to bring the study and the total program to fruition. Their expertise and encouragement have been greatly appreciated.

Special acolades go to the Berrien Springs Public

Schools and the Berrien County Day Program for HearingImpaired for their cooperation throughout the study. A special note of appreciation goes to the high school and middle school English teachers for their assistance in the testing.

The untiring and unending support of my wife, Hazel, has always been tine catalyst that helped me to reach my goal. Her patience and longsuffering is greatly appreciated and esteemed. I am eternally grateful for her support.

For all who have contributed to bringing this dissertation to completion, I want to express my sincere appreciation.

viii 
CHAPTER I

INTRODUCTION

There are many factors which may exert an enhancing or detrimental influence in the ability of a child to achieve success in the world. One such factor is selfconcept. A child's self-concept is formed on the basis of how others respond to the child, what the child thinks of himself, and what the child would ideally like to be (Gordon, 1968; Quandt, 1972, p. 5).

All children need feedback from their relatives and friends because of a lack of experience and because defense mechanisms can warp their self-perceptions (Lugo \& Hershey, 1979, p. 147). Since self-perceptions or self-concept is learned, not inherited, attitudes toward the self can be altered when one encounters a positive experience with people and life (Van Pelt, 1976, p. 27). Much of this positive experience is through a child's interaction with his parents. The parents' loving and caring for him are a strong contributing factor to the foundation on which all future reliable behavior is built, for it influences how the child feels about himself (Van Pelt, 1976, p. 75). 
There are many difficulties that are the result of the consequences of faulty perceptions that people have of themselves (Crafts, 1975). Results of recent studies indicate that academic ability is associated with academic success of the student at individual different grade levels (Brookover, Erickson, \& Joiner, 1965; Wylie, 1974). At the same time, psychologists are very interested in the self-concept as it affects a person's occupation, academic success, and interpersonal relationships (Brookover et al., 1965).

\section{Statement of the Problem}

One of the main problems of the handicapped child is whether or not the child can develop an adequate selfconcept in the regular school setting. This is an especially big problem for the hearing-impaired child in a regular school setting. Can the child be expected to have a self-concept that is as good as that of the normal-hearing child? In the Berrien County Day Program for Hearing-Impaired, teachers and administrators have taken the position that the hearing-impaired child can develop a self-concept that is as adequate as the normalhearing child in the Berrien Springs Public Schools. Also, the hearing-impaired child can develop a selfconcept that is as good as or better than the norms for each grade level.

An interesting fact about human behavior is that 
whether the self-concept is good or bad, if the treatment a person receives is consistent with his self-concept, that concept is fortified (Kiester, 1973, p. 1). Unquestionably, teachers, along with parents, relatives, and other students, can have a great deal to do with the development of the child's self-concept (Kiester, 1973, p. 7).

A child's self-concept usually goes through three stages of development. The first stage in the development of the self-concept is the parents' treatment of the child; the second is the child's perception of society's evaluation of the child's family, including himself; the third is the child's accumulation of experiences with success and failure. At any age, success in human relationships is just as important as experience with other kinds of achievement (Kiester, 1973, p. 75).

The problems for the hearing-impaired child are particularly concerned with the development of an adequate personality structure and with the establishment of an appropriate system of interpersonal attitudes and relationships (Rodda, 1970, p. 10). Because of a lack of information about the interaction of the hearing-impaired child and his environment, interpretation of the differences found between the hearing-impaired child or various categories of the hearing-impaired child and the hearing child must be tentative. 
There is an obvious need for careful, detailed observation of the behavior of the hearing-impaired child in naturalistic settings to determine whether environmental challenges for the child are different from those for the hearing child and the extent to which such differences require different modes of adaptation (Moores, 1978, p. 103).

This also raises the question: If the development of an adequate self-concept is contingent upon the ability to express needs, wants, and desires (Mead, 1934), what is the self-concept of the child who cannot describe to his parents or teachers his individual feelings about his environment (Moores, 1934, p. 105)? The lack of verbal communication between the hearing-impaired child and the child's peer group may present problems that could result in the development of a lower self-concept.

\section{Purpose of the Study}

The purpose of the study is to ascertain if the hearing-impaired students at the Berrien County Day Program for Hearing-Impaired have developed self-concepts that are as adequate as that of the hearing students of the Berrien Springs Public Schools. Also the study compares the self-concept scores of the hearing-impaired students and hearing students with the national norms as established by the Piers-Harris Children's Self-Concept Scale. 


\section{Significance of the study}

Cooley writes that certainly the discovery of self-image is one of the most important finds of this century (1922). Even though the student does not realize it, the student carries a mental blueprint or picture of himself. All of the child's actions and emotions are consistent with the imagined self-image. The child acts like the sort of person the child thinks he is. A child simply cannot do otherwise, and the person who thinks he is a failure will fail. At the same time, the person who seems himself as a success will have a much greater chance of succeeding (Cooley, 1922).

The self-image is the foundation stone of one's whole personality. Because of this, experiences and environment seem to verify the self-image, and as a result, create a vicious or pleasant cycle for the individual and his life (Cooley, 1922).

This research ascertains to what extent the hearing-impaired student has developed a self-concept that is equal to or superior to the self-concept of the hearing student. It does this by comparing the selfconcept of the hearing-impaired students of the Berrien County Day Program for Hearing-Impaired with the selfconcept of the hearing students of the Berrien Springs Public Schools. 


\title{
Berrien County Day Program for
}

Hearing-Impaired

\begin{abstract}
Approximately 130 children and youth with an educationally disabling hearing loss are enrolled in the Berrien County Day Program for Hearing-Impaired. This program is operated within the framework of the Berrien Springs Public Schools. Students come from the Michigan counties of Berrien, Cass, and Van Buren. They range in age from infants of less than one year old to high-school graduates. The students use the facilities of the Berrien Springs Public Schools. However, due to their handicap, they attend school one hour longer than the hearing students. This gives them the opportunity to receive special speech instruction or other needed classes. The hearing-impaired students, where appropriate, are mainstreamed into regular classrooms. The amount of mainstreaming for each student is determined by the school psychologist, the teacher of the hearingimpaired student, the head teacher of the herringimpaired, and the parents of the hearing-impaired student. The hearing-impaired students also share the comnon experiences and facilities of physical education classes, cafeteria, restrooms, and extracurricular activities with the hearing students.

The current director of the hearing-impaired school, Andrew Gattenbein, started the school in 1963 with fifteen children. Since then over 250 children have
\end{abstract}


attended the school. These include children from eighteen states and eight countries. The Berrien County Day Program for Hearing-Impaired maintains a fleet of station wagons and small schools buses to transport those students who live outside of the Berrien Springs Public School District and do not ride the regular buses of the district.

The school from its beginning has used the oral method of teaching the hearing-impaired. The philosophy of the school states:

- . since the children are going to live in the hearing world they must know how to communicate with people they must come in contact with. The success of the school is determined by the success of its students. Presently, students are attending college, working as laborers, and in general filling various types of occupations that any typical high school graduate would. (Gattenbein, 1980)

\section{Statement of Bypotheses}

The hypotheses are stated as research hypotheses rather than as experimental hypotheses. Significance for all hypotheses is tested at the .05 level. This research tests the following hypotheses:

1. There is no significant difference between the self-concept of the hearing-impaired students of the Berrien County Day Program for Hearing-Impaired and the students of the Berrien Springs Public Schools.

2. There is no significant difference between 
the self-concept of the hearing-impaired students of the Berrien County Day Program for Hearing-Impaired and the national norm as established for the Piers-Harris Children's Self-Concept Scale.

3. There is no significant difference between the selr-concept of the hearing students of the Berrien Springs Public Schools and the national norms as established for the PiersHarris Children's Self-Concept Scale.

\section{Delimitation}

This study is limited to the students of the Berrien Springs Public Schools and to the hearingimpaired students früm Birrien, Cass, and Van Buren counties of Michigan that attend the Berrien County Day Program for Hearing-Impaired.

\section{Definition of Terms}

Some of the terms used in this research study have special meaning and are defined as follows:

Self-concept. Self-concept is the person's total appraisal of his or her appearance, background and origins, abilities and resources, attitudes and feelings which culminate as a directing force in behavior (LaBenne \& Green, 1969, F. 10). In this study, the term is used synonymously with self-image and self-csteem. 
Hearing-impaired student. Any student that has a hearing loss greater than twent $\ddot{y}$ decibels is a hearingimpaired student (Furth, 1973, p. 8).

Teachers of the hearing-impaired. Teachers who have received special training at the university level so they can work more effectively with the hearing-impaired students.

Berrien Springs Public schools. A tax-supported school district comprising fifty-two square miles located in central Berrien County, Michigan. It serves about 2200 students in grades kindergarten through twelve.

Hearing students. Students attending the public schools who have no measureable hearing loss or have a loss that is less than twenty decibels.

Attitude. Attitude is a more or less stable set or disposition of opinion, interest, or purpose involving expectancy of a certain kind of experience and readiness with an appropriate response (Drever, 1952, p. 123). Behavior. Behavior is the total response which a person makes to a situation with which the individual is faced (Drever, 1952, P. 28).

\section{Assumptions}

The basic assumption of this study is that the self-concept is influenced by growth, maturation, experience, and environment. It is also assumed that a 
student's self-concept is influenced by his positive or negative association with his family, peers, other adults, and teachers. Another assumption is that a student, when responding openly and honestly to a selfreport inventory, is aware of his self-concept even though the student may not know it by this term (Wylie, 1961, P. 313) .

Since the student knows himself, it is assumed that the student can give the most accurate picture of his self-concept. Even though a student would have a tendency to overestimate or underestimate himself on some items, "those traits on which a student would have the most objective evidence, on a basis of permitting him to compare himself uniformly to others, are usually the most accurately estimated. . . " (Wylie, 1961, P. 314).

\section{Organization of the study}

The organization of the study is as follows:

Chapter I includes the introduction, statement of the problem, purpose of the study, significance of the study, description of the Berrien County Day Program for HearingImpaired, statement of hypotheses, delimitation, definition of terms, and assumptions.

Chapter II gives the review of literature which is divided into historical perspective of self-concept, measurement of self-concept, development of individual self-concept as it pertains to the hearing-impaired 
individual, and hearing-impaired education.

Chapter III describes the research design, null

hypotheses, description of population, and the instrument used in the study.

Chapter IV presents the data of the study.

Chapter $V$ summarizes the findings of the study

and presents the results, recommendations, and conclusions. 
CHAPTER II

REVIEW OF LITERATURE

In this chapter the literature relevant to this study of self-concept is reviewed. The review is organized into the following areas: historical perspectives of self-concept, development of individual self-concept, measurement of self-concept, self-concept as it pertains to the hearing-impaired individual, and hearing-impaired education.

\section{Historical Perspectives of Self-Concept}

Early writers on self-concept

One of the early leaders of psychology, william James (1890, p. 191), gave the concept of self an important place in his psychological writings. He considered ego the individual's sense of identity. In addition to this global concept, he felt that self included spiritual, material, and social aspects. James gave the self a dynamic quality in terms of seeking one's selfpreservation.

About half a century after James' writings, a number of theorists began to establish and to state their conccpts of self. All used the term self as having one 
of three meanings: (1) a dynamic process; (2) a system of awareness; (3) an interrelated process and awareness (LaBenne \& Greene, 1962, p. 2).

Freud (1943) gives the ego a central place in his theory of personality structure. However, Freud pays little attention to self-image. Racher, for him the ego is a functional agent or executive of the personality which makes rational choices and controls action in a healthy person.

Allport (1937) articulates on tine interaction of the self as both object and process with a measure of clarity. He avoids the use of the term self so that he would not be an agent of the prescientific psychology. Allport calls the ego or self functions the controlling functions of the personality. He states that the terms self and ego should be used as descriptive adjectives to indicate the controlling function of the personality. Mead (1934) makes the concept of self a major part of his theoretical writing on the philosophy of society and describes in detail how the self is developed through transaction with the environment. Mead further states that personality is determined by socialpsychological factors. Various selves are differentiated by the specific set of responses in different social settings. 
Life space and self-concept

According to Lewin (1939), the self-concept represents a life-space region which determines present belief about one's self. The term life space is a psychological concept meaning the individual's universe of personal experience or a space in which he or she moves. Life space can be considered a complex internal mechanism which produces behavior. All of the variables that determine the direction of behavior lie in the life space of an individual. To predict behavior, one must know the life space of an individual when the behavior is to occur.

Subjective and objective self

Iundholm (1940) distinguishes between a subjective self and an objective self. The subjective self is mainly what a person comes to think of himself or herself. The subjective self can be changed by the experiences that result from the interactions with others. The objective self is the outward behavior that actually can be measured.

Symond (1951) incorporates the psychoanalytic theory of Freud and the social philosophy of Mead. This combination gives theory in which the ego is a group of processes while the self is a manner in which the individual reacts. Symond also cautions that a person may be unaware of his true self-conceptions due to unconscious 
distortions. In other words, what a person says may not necessarily agree with the individual's unconscious selfevaluation.

\section{Self as an organizing influence}

Cattell (1950, p. 131) considers the self the principle organizing influence exerted upon man which gives stability and order to human behavior. There is a difference between the concept of self and the sentiment of self. The sentiments of self-regard are the most important influences in man. Cattell continues by saying that sentiments are the "major acquired dynamic trait structure which causes individual[s] to pay attention to certain objects, or class of objects, and to feel and react in a certain way without regard to trien." He also introduces the process of self-observation. The self which a person must rationally admit to is the actual or real self, while the self to which a person aspires is the ideal self. This means that the self is both an object and a process.

Defensive-enhancing functions of self

Murphy (1947, p. 142) expands the objectified self and delimits the self process to "defensiveenhancing functions." Self is defined as the individual known to the individual. This comes from the person's conceptions and perceptions of a person's total being, 
including the frustrated self and the ideal self. The defense mechanisms are then the ego processes. This gives the ego the major function of protecting or enhancing the self-concept.

Discontinuity of unconscious and conscious self

Rogers (1951) believes in the discontinuity of the unconscious and conscious. The implications are that only when the information about the environment is admissible to awareness does it influence behavior. Rogers continues:

As long as the self-Gestalt is firmly organized, and no contradictory material is even aimly perceived, then positive self-feelings may exist, the self may be seen as worthy and acceptable, and conscious tension is minimal. Behavior is consistent with the organized hypotheses and concept of selfstructure. (p. 191)

The consistency between behavior and self-concepts indicates the dual role of self: self as object and self as process.

Self and behavior

Snygg and Combs (1949, p. 15) claim that "all behavior, without exception, is completely determined by and pertinent to the phenomenal field of the behaving organism." This means a person's behavior is the result of how the situation is perceived and how the person is at the moment of action. As snygg and combs state that "the self is composed of perceptions concerning the individual 
and this organization of perception in turn has vital and important effects upon the behavior of the individual" (p. 470).

Evaluation of self and feelings for others

Froom (1939) is one of the first to observe the close connection between a person's evaluation of self and feelings for others. Froom notes the importance of self-love for human happiness and considers low selfesteem and excessive feelings of humility a form of neurosis.

Neo-Freudians like Horney and Sullivan have extended psychoanalytic theory in a direction useful to the self in psychopathology. Horney $(1936,1950)$ gives an understanding of the neurotic forms of self-love and self-alienation. Sullivan (1947, p. 33) indicates that the self is made up of reflected appraisals. Initial personifications of good-me, bad-me, and not-me by the developing infant as a result of his interactions with significant others gradually evolve into a self-system. This self-system is important as a concept for understanaing the problems of one's interpersonal relations-positive or negative--in the functions and the relationships with others (p. 53).

\section{Hierarchy of needs and} self-concept

In Maslow's (1954, 1959) hierarchy of needs, a 
positive level of self-esteen is the final prerequisite for self-actualization. Once the individual's selfesteem is achieved, he is free to concentrate on actualizing his potential. Self-esteem is also considered to be a primary component by Coopersmith (1976) and Purkey (1970).

This historical review of the major theorists gives a background of the development of the self-concept and some of the components of self-concept.

\section{Development of Individual Self-Concept}

Parent-child interaction and environment

Wylie states that all personality theorists who are concerned with the constructs involving the self place great importance on the parent-child interaction in the development of the child's self-concept (1961, p. 121). Woolsey (1975, p. 8) writes: "The most important shaping factor in our personality is our environment during the first two or three years of our life." Ainsworth and Bell (1969) suggest that early experience can have a significant effect on later development of the child. This early experience exerts its influence by setting up patterns of perception, expectation, and action which interact with other environmental influences to set up continuities in the development process across wide segments of the developmental years (p. 162). 
David and Appell (1969, p. 183) discovered that this interaction is also a means of showing expression of emotional attitudes. The spontaneous impulses and behavior of the child produce strong feelings in the mother. Her reactions to the different areas of the child's behavior create patterns in the child's behavior and patterns for their development. In all areas, the emotional attitudes of the mother and the child tend to correspond or be similar.

Psychoanalytic-oriented theorists have universally stressed the importance of the early environmental influences upon the personality of the child. Anna Freud (1943, pp. 65-113) stresses that the children taken out of London during the Second World War were not so upset by the hazards of the war as they were by the separation from their parents. She postulates that the emotional relationship of the young children to their parents is significantly related to personality development.

She also observes that the children under the age of three forget their parents within a short time but that the older children do not. The children, in time, experience negative feelings toward their parents. If these children are separated from their parents at an early age, they internalize as correct their destructive powers. This arouses an intolerable anxiety which could interfere with normal ego development. Anna Freud notes 
that the ability to love is learned at this early age and that later love relationships follow this problem of early childhood. Therefore, if early relationships with parents are absent, the ability to love may be absent and subsequent relationships may have a tendency to be weak and shallow.

Father's influence on self-concept

Coopersmith (1969, pp. 87-90) suggests that the father and his work history may have a profound effect on the self-esteem of the children. In the effective, interpersonal environment of chiluren, a father's doubt about his powers assume considerable significance. The relationship between self-esteem and regularity of employment is one of the important factors that affects children and their attitudes toward their parents. This in turn has an effect on the children's self-concepts.

Another factor which affects the self-esteem of children is the father's intermittent absence from the home. This does not lower the children's estimate of themselves, but results in an uncertainty about how valuable they are. This may result in defensive reactions, especially if the mother states that the father is unable to provide occupational stability (Coopersmith, 1969, p. 89). The resulting uncertainty of confused children as to their value is reflected in their sensitivity to 
criticism and public self-aggrandizement. This suggests that defensive reactions are likely to result from uncertain self-esteem rather than a low opinion of worth. One can conclude that the father's occupation is one of the major determinants of a family's status and that this status can have an effect on the status and the selfesteem of children (p. 92). However, the importance of this status should not be overwhelming and should not be considered the only factor affecting the self-esteem of the children. Coopersmith found too many exceptions for this to be considered the most important factor in the lives of the children.

Coopersmith (1969, p. 256) also reported that the "parents of children with high self-esteem are more attentive and concerned about their lives outside their families; they are more likely to spend time with their children than are the parents of children with less selfesteem." The main difference is that the families of children with high self-esteem are marked by well-defined limits of behavior and clear statements of rights and privileges. They also have a greater tolerance for selfexpression and less drastic forms of punishment. In short, they have a more democratic style of family life.

A number of factors play important roles in the development of self-concept. Hurlock (1967, p. 655) states that, in general, these factors have high prestige 
in the eyes of the peer group. Some of the factors involving the family and self-concept are controllable, while many others are not.

\section{Developmental stages} and self-concept

Erickson's writings on the psychological stages of development substantiate the writings of Anna Freud. He states that if trust is not developed during infancy, children suffer ego impairment and have difficulty identifying closely in intimate relationships in their adult life. The ego problem associated with the failure to accomplish the developmental tasks of Erickson's developmental periods has been widely reported. The periods of genital (ages 4-5), latency (6-12), and puberty and adolescence (ages 13-18) are of special interest to this study. These periods may result in the dichotomus ego qualities--initiative versus guilt, industry versus inferiority, and identity versus role confusion--being poorly developed. The resulting effect could cause problems for the adult relationships in later life (Erickson, 1950).

Basic needs of the child and self-concept

Yamoto (1972, p. 188) writes that there appears to be several basic needs which must be fulfilled if a child is to consider himself a worthy person. These 
needs are met in the reciprocal love relationship between parent and child. The prime parental behaviors which make up the relationship of love and which appear to have the greatest effect on self-esteem are: (1) consistent acceptance with respect and concern, and (2) freedom with high self-regard within carefully defined limits. The person with high self-regard usually has experienced a combination of these qualities.

\section{Judging self-worth}

Felker (1974, p. 57) noted that during the preschool period, the child begins to judge self-worth partly on the basis of the child's competence with objects, with peers, and with adults. The child who has not developed a sense of belonging and security that accompanies such a sense is likely to be hindered in moving out into the wider world. Security provides the basis for the confidence that the child can meet the world without excessive fear. Once a child steps out into the wider world, the competence which develops tends to enhance the beginnings of positive self-esteem. The fearfulness and lack of confidence reinforces the beginnings of a negative self-concept.

\section{Self-concept and social contacts}

LaBenne and Greene (1969, p. 13) believe that the self-concept is built or achieved through accumulated 
social contacts and experiences with other people.

People learn their identity, who and what they are, from the kinds of experiences that the growing-up process provides. Sullivan (1947) called this "the development about self from the mirror of other people." What people believe about themselves is partly a function of their interpretation of how others see them. They infer this from their behavior toward them. Therefore, the concept of self rests in part on what people think others think of them (LaBenne \& Greene, 1969, p. 14).

Baumrind (1965, pp. 230-34) says that a combination of parental warmth and firm discipline is likely to produce self-reliant, bouyant, self-controlled children. Coopersmith (1967, p. 117) supports this observation. He also reports that the most notable antecedents of high self-esteem are directly related to parental behavior and the consequences of rules and regulations that parents establish for their children. This is illustrated by the statement that definite and consistently enforced limits on behavior are associated with high self-esteem; that families which maintain clear limits, utilize less drastic forms of punishment, and produce high self-esteem children exert greater demand for academic performance and excellence.

Formation of self-concept

Fiske and Bolgar (1962, p. 344) report that it is 
clear a person is not born with a self-concept but forms one out of experiences. Important as a person's selfconcept is, it seems to be almost a by-product of other learning experiences. An expression of pleasure following some achievement is one of the earliest clues that a child is beginning to develop a kernel of self-concept. Minchin (1977, p. 82) writes that the understanding of self is a commonly accepted developmental goal. In the middle years, children move toward such a goal in two ways: through increasing objectivity and greater lifferentiation. Objectivity means these children can think about themselves as separate beings who are viewed and evaluated by the self and others. Greater differentiation increases their knowledge of what they are like as individuals.

\section{Objectification of self-concept}

Objectification has special qualities and limitations in relation to the self. An individual's knowledge of self needs to include awareness of feelings, of conflicts, and of the meanings of what others do. It is toward this complex integration that children begin to move when they come to understand that they can think about themselves and that they are objects of thought and evaluation by others (Minchin, 1977, p. 83).

Self-image becomes more differentiated as well as more objective during the middle years. The 
self-perception of children contains an increasing range of detailed content, including a growing knowledge of personal qualities, competence, impact on others, fantasies, feelings, and emotional style. The growth in differentiated self-perceptions is part of the general growth of delineated and organized patterns of thought. It is also the product of an expanding world in which the new activities of the school and the neighborhood as well as the expanding contact with other children and new adults give children constant feedback about self (Minchin, 1977 , p. 84).

According to Coleman (1960, p. 293), a realistic self-concept is an important component of sound mental health. He writes: "It is generally true that when most people see others very differently from the way they see themselves, their self-image is somehow inaccurate and they are probably headed for trouble" (p. 292).

\section{Self-concept's influence} on behavior

$$
\text { Gergen (1971, p. 90) states that self-concept }
$$
influences behavior. Negative feelings toward self may produce negative behavior toward others. Persons with low self-esteem are less prone to influence others and more inclined to be influenced by others. One's estimate of self also strongly influences goals and behavior in reaching these goals. This means one's sorial identity is determined by self-concept. The individual's private 
emotional life, as well as his relationship with others, is influenced by self-concept (Gergen, 1971, p. 91).

Teaching influences on

self-concept

Erickson (1968, p. 122) theorizes that when children reach school age they receive some systematic instruction, although it is not always in the schoolroom. Most of the time teachers, specialized in disciplines, provide the children with knowledge which, first of all, makes them literate. When society's specialization is greater, the goal of initiative becomes more indistinct. As society becomes more complicated, the father's and mother's roles are less clearly defined. Between childhood and adulthood, children go to school. The skills they learn in school often seem to many to be a world with its own goals and limitations, its own achievements and disappointments. One of the most difficult tasks of the developing child is to incorporate the school world into the child's total self-concept and real world.

\section{Self-concept in scholastic} success

$$
\text { Purkey (1970, p. 65) explains that there is a }
$$
dynamic interaction between the self-concept and scholastic success. One of the main tasks of the teacher is to aid the children in building positive and realistic self-concepts. If the self-concept is made an integral part of the curriculum, it is the result of the teacher's 
careful planning and instruction. As the self-concept of the student is improved, the teacher's self-concept is enhanced because of the success with the student.

Self-concept during adolescence

Kizzar and Hagedors $(2379$, p. ix) feel that an adolescent's self-evaluation is the most important factor in determining a response to peer-group pressure. Adolescents with inadequate self-esteem usually are those who follow the crowd and its dictates; disregarding the values and ideas instilled by their families. Research indicates that increasing numbers of young people are swayed by peer-group pressure and are poorly equipped to go against the crowd. Positive parental judgments and unqualified support are the decisive factors in enabling young people to resist negative peer pressure (p. 2). Kizzar and Hagedorn (p. 3) continue that an adolescent is extremely vulnerable to judgments expressed by those in the adolescent's immediate environment because at this stage in life the adolescent is concerned with the opinions of others. The peer group and their opinions help to form the adolescent's self-concept. To develop this self-concept, one of the important needs is the acceptance of significant others. These include love in the home, esteem and regard from peers, and respect from teachers and employers. An individual who has been hurt in peer interaction usually tends to withdraw or to build 
psychological defenses and protective barriers (p. 5).

Social environment and

adolescent self-concept

Schwarzrock and Wrenn $(1973, \mathrm{P} .28)$ state that

cultural heritage, family experiences, socio-economic position, emotional make-up, and the ability to communicate all mold an individual so a person unconsciously responds to life situations according to the way each one has been taught. Unconscious reactions often create impressions of which one is unaware. The resulting selfconcept can be different from the impressions that others have.

Elkind (1971, p. 111) points out that - . during adolescence the young person develops a true sense of self. While the children are aware of themselves, they are not able to put themselves in other people's shoes and to look at themselves from that perspective. Adolescents can do this and do engage in such self-watching to a considerable extent. Indeed, the characteristic selfconsciousness of the adolescent results from the very fact that the young person is now very much concerned with how others react to him. This is a concern that is largely absc:

Okun and Sasfy (1977, p. 377) write that the self-consciousness and apprehension about how others see the person reflect the tenuous and somewhat unstable nature of the adolescent's self-concept. This selfconcept is very susceptible to discomforting evidence. The adolescent is always gathering evidence to support a perceived self-concept. Therefore, the driver's license 
or the first date is of vital importance.

Flora (1978, p. 101) for.nulated the concept that the adolescent's self-concept has a significant effect upon the adolescent's perceived communication with parents. The adolescent with low self-concept perceives social interaction and communication with his parents as significantly more non-constructive than the adolescent who has a higher self-concept.

Adolescence is characterized by Erickson (1950, p. 81) as the period in wilch the individual must establish a sense of personal identity and avoid the dangers of role disfusion and identity confusion. The search for an identity involves the production of a meaningful selfconcept in which the past, present, and future are linked together. Therefore, the task is more difficult in a historical period when the past has lost the anchorage of family and community tradition, the present is characterized by social change, and the future has become less predictable. In a rapidly changing society, the search for identity is taking place of the socialization process. Muus (1975, p. 266) states that the adolescent faces the task of incorporating into his or her selfconcept those sex characteristics that are culturally acceptable. New social relationslips must be established during adolescence, especially heterosexual relationships, but also new social relationships within one's own sex aroup. 
Adolescent stress and

self-concept

Manaster (1977) notes that probably the most frequent and continual description of adolescence is a time of stress and upset. There are very usual, normal reasons for upset in the life-task areas in adolescence. Many of these are situationally fomented in interaction with developmental change. The self-concept and its differentiated parts may be affected by adolescent situations. The new situations of the adolescent cover love and sexual behavior, new social situations, new school settings, larger school course offerings, demards of educational choice, and vocational exploration. The effectiveness of coping has a profound effect on self-concept.

Self-estimate and ego aspirations

Ausubel, Montemayor, and Svajian (1977, p. 160) write that there are many reasons for placing the selfconcept in a prominent place in the individual's psychological field during adolescence. The adolescent makes considerable upward revision of self-estimate and ego aspiration. The adolescent appears concerned with more precise verbalization of his feelings about himself. Concern with intellectual status and social relations have considerable self-reference and are important sources of self-esteem in the adolescent. Preoccupation with heterosexual activities can be useful as a contrast 
medium for self-expression and sharper definition of individuality.

Ausubel, Montemayor, and Svajian (1977, p. 161) continue by saying that adolescence is a period of ego aspirations and self-estimate. In contrast to the early crisis of evaluation, it may be regarded as a time of ego reevaluation. All of the maturational tasks of adolescence have ego-inflationary implications. This is confirmed by the adolescent's fantasy which usually places the adolescent in the role of hero or in an amorous situation.

Combs, Avila, and Purkey (1971) write that the importance of the individual goes beyond providing a basis for reality. Its very existence determines what else the adolescent may perceive. The self-concept has a selective effect upon perception. A person tends to perceive what is congruent with already existing concept of self. An adolescent who sees himself as male perceives what is appropriate for a male to perceive. An adolescent who sees herself as female sees what is appropriate for a female to perceive. Once established, the self-concept, thereafter, provides a screen through which everything else is seen, heard, evaluated, and understood.

Aspiration influence on self-concept

The theory that the adolescent's level of 
aspiration has a marked influence on individual selfconcept is supported by Hurlock (1967). The reason for this is that the level of aspiration determines whether one sees one's self as a success or failure. When the adolescent is successful in reaching a personal goal, the adolescent has a feeling of self-satisfaction and self-confidence. Failure to reach a goal can undermine the self-confidence of the adolescent and lead to the feeling of personal inadequacy (p. 663). Once an adolescent has acquired the habit of unrealistic aspirations in either direction, the youth resists change. To offset this, many parents and teachers believe that expressing a level of aspiration serves as an important motivation to reach the goal. This forces the adolescent to literally sign on the dotted line and to achieve in order to save face. Talking about aspirations raises the adolescent's prestige in his own eyes and in the eyes of peers, but is the resulting psychological damage caused by failure worth the temporary ego satisfaction the adolesent receives (p. 663)?

Purkey (1970, p. 42) writes that the image of school grows less positive with the passing of time and communicates to the adolescent a sense of inadequacy. If the school is serious about understanding the place of the student's self-concept in the student's school success, it needs to seek ways to modify its curriculum and 
methods. This would help to eliminate the negative selfconcepts in the adolescents.

Sievert (1976, p. 50) indicates that adolescenis who demonstrate a low positive or negative self-concept do not make realistic occupational choices. These adolescents do not see themselves as the same type of person as the typical worker in a chosen field. Perhaps the vocational programs of the schools should place more emphasis on providing the adolescents with vocational programs that are more compatible with the student's perceptions of themselves.

Unfinished adolescent tasks and self-concept

Jersild (1957, p. 16) reports that the adolescent not only continues to work on many tasks begun in earlier years but also leaves unfinished many tasks that are the business of adclescence. These tasks are finished in the adult years. There is something of the uncompleted work of adolescence in every adult. The big issues with which the adolescent strives--issues relating to self-concept, to acceptance or rejection of authority, association with the opposite sex, and responsibilities that should be accepted or rejected--are not completely settled just because one has officially finished the adolescent years of life.

There are issues that the individual must face 
throughout life. In the typical life, as long as the individual continues to think and act, there will be problems to grapple with and decisions to make. Each of these actions or thoughts may have a profound effect on the self-concept of each person. This in turn could have a profound effect on life and the success or failure in life.

\section{Measurement of Self-concept}

Types of research on self-concept

Self-concept research has been conducted largely by using psychometric approaches similar to achievement. Garwood and Garwood (1978) report that the self-concept is assumed to increase in a linear fashion until some ceiling established by a particular scale is reached. One of the unfortunate results of such an approach is that it tends to deny that the self-concept may have a qualitative as well as a quantitative nature.

As Wylie (1974) points out, self-concept research lacks cohesiveness. There are too many unreplicated studies, too many self-concept instruments, and too little theory. Because of this, self-concept appears to be set apart as an entity unto itself.

\section{Definition of self}

In search of a viable definition of self, Sarbin (1971, pp. 22-23) stated that the notion of self is 
defined 25 both a process and a structure. This is given as "that process by which the person conceptualizes or categories his behavior--both his external conduct and his internal states." Using the structural level, it is "the system of concepts available to the person attempting to define himself." Put into simple terms, this means what the individual thinks of himself as an object in society.

Limitation of self-concept measurement

LaBenne and Greene (1969, p. 11) report that because the self-concept cannot be seen, severe limitations are placed on any attempt to measure it at any given point in time.

If the self-concept is to be measured, how can a researcher expect to accomplish this feat? While it is true that self-concept cannot be seen, the behavior resulting from the self-concept can be seen and reported. In order to obtain this information efficientl $;$, the psychometrists have developed a variety of tests to gather information about behavior patterns. Most of the tests require that a person gives information about himself. Even though this is limited, no one has the knowledge of the inner person and the private thoughts as deeply as the person.

Benjamins (1950, pp. 473-80) cautions that the 
individual's statements about himself may not represent how the person feels. When the self-report is inaccurate, there is not an accurate measure of the self-concept. The person's statements about himself do not directly control that individual's behavior, but the way a person actually feels controls normal behavior. Therefore, it is hoped that the basic honesty of the subject enables the individual to give accurate information on such tests.

Coopersmith $(1968$, p. 8) writes that by the age of ten or twelve, the individual "appears to have sufficient experience and ability to think abstractly, so that he can make general assessments for his powers." This is the age at which the self-report inventory is initially used in the research on self-concept.

Crandall (1973, P. 47) notes that usually selfconcept is directly tapped by asking people how much they like themselves. Dimensions of self-concept emerge when the people are asked about their responses to some different aspects of themselves: physical, mental, moral, in school, with people, at work, etc. At times, the researcher is tempted to weigh items according to their importance to self-concept. However, there is no convincing evidence that added validity is gained by this weighing. of items. 
Validity of self-concept

research

The central problem in self-concept research is validity. The general lack of work in this area makes it easy to criticize all existing scales (p. 51). Research must deal with careful operationalizations to make self-concept research valuable. When the results are negative, the construct suffers even if its measuring devices are at fault.

Crandall continues (p. 54) that there are two ways measurement can improve: "first, if new scales are introduced which are supported by massive validation data, and second, if the usage is concentrated on a few scales causing the gradual accumulation of validity data." People interested in self-concept need not resolve all measurement problems. If a careful validation program is undertaken with the realization that it is a project that could last for many years, self/self-concept measurement can be established with a firm foundation. Many hundreds of items need to be tested against a multi-determined criteria on large replicated samples. This would serve as the foundation of validity that would stand the test of time (p. 58).

Early reports of self-concept research

Wylie (1961) gave the first detailed study of the different instruments and methodologies of various 
studies in the field of self-concept evaluation. She states that "the total accimulation of substantive findings is disappointing, especially in proportion to the great amount of effort which has been extended" (p. 317). She concluded that this is because the constructs are stretched to cover so many inferred cognitive and motivational processes that "their utility for analytic and predictive purposes has been greatly diminished" (p. 318). Perhaps these over-generalized, self-referrent constructs should be more precisely reformulated.

\section{Two recommended self-concept}

\section{scales}

Robinson and Shaver (1976, p. 57) write that - . two of the most widely recommended scales--the Tennessee Self-Concept Scale and the Piers-Harris Children's Self-Concept Scale--have the best overall quality. Tho Tonnessee Self-Concept Scale, a 100-item form which includes a ten-item scale from the MMPI, has been administered to all but the youngest age groups. The carefully written and widely used Piers-Harris Children's Self-Concept Scale is used with younger age groups but can be used through the high school years.

The main difference which makes these scales superior to the others is the careful work that their creators have put into them.

The Piers-Harris Children's Self-Concept Scale has been developed especially for work with children (Robinson \& Shaver, 1976, p. 73). Its items cover many areas of self-concept, particularly physical aspects, abilities, and personality. It is a useful scale for the 
researcher. However, it is important to remember that for research purposes not all of the scales should be used to definitely place the children into various categories; they are merely indicators of general behavior. The Tennessee Self-Concept Scale was developed from a clinical perspective. It measures self-concept across many sub-areas providing both an overall selfesteem score and a complex self-concept profile. This scale has many positive attributes that one would look for in a scale. However, it could be improved by including some information on clinical-behavior criteria such as peer ratings (Robinson \& Shaver, 1976, p. 69). Buros (1972, pp. 306-7) states that the piersHarris Children's Self-Concept Scale consists of eighty first-person declarative statements. The scale has been developed not only as a psychometrically adequate scale but also as a direct and honest evaluation. The research use of the scale is emphasized. This is due to the fact that the application of the scale is not completely validated.

Buros continues that the scale is designed as an unidimensional scale. The six factors of the test must be used with great care as they are primarily designed for research and are not intended to label students. These factors need more validation before they can be used by a researcher in any study of the general 
population. The scale is designed to be interpreted by using the manual that the Piers-Harris have developed.

Some of the more admirable features of the manual are its accuracy and cautions. For example, the principle component analysis suggests that the combinations of items can be scored to yield cluster scores. The manual indicates that the cluster scores are at the moment sufficiently tentative that their application should be in research.

After consultation with the director of the Berrien County Day Program for Hearing-Impaired, the researcher determined that the Piers-Harris Children's Self-Concept scale would be the most appropriate for this study. The yes-no answers made it easier for hearingimpaired students to formulate answers. One of the problems for the hearing-impaired students in their academic work is language and reading. Therefore, this scale fits the needs of the hearing-impaired students better than the more difficult-to-read Tennessee Self-Concept Scale. In addition, the Piers-Harris Children's Self-Concept Scale can be used for all grade levels involved in the study.

\section{Self-Concept Development of Hearing-Impaired}

Special needs of the hearing-impaired

Myklebust (1950, p. 34) supports the concept that 
a hearing-impaired child is not different from the hearing child so far as the child's fundamental needs are concerned. The hearing problem dictates that the child's needs must be met and satisfied in a different way. Usually, this means that the training for the hearingimpaired child is more concrete and direct than that for the hearing child. The hearing-impaired child requires more careful demonstrations and explanations than does the hearing child.

Myklebust also points out (p. 15) that the child born with a hearing deficiency does not have a sterotyped personality. Just as the hearing child is different from the child's peers, so the hearing-impaired chlla aevelops a unique personality that is different from other hearingimpaired children. All types of personalities are present in hearing-impaired children.

Self-concept and social adjustment

Meadow (1976, p. 74) states that the growth of self-concept or identity goes hand in hand with social adjustment. As a child begins to be an object of himself as the child sees himself reflected in the appraisals of others, the child begins to understand both others' behavior and his own. The child gets a sense of selfworth from the reactions of others. At first the 
important others are the immediate family members, but as the circle widens, the self-image is affected by the responses of other family members, teachers, peers, and others. The positive or negative meanings attached to responses to the child's "differentness" are very important to the development of the hearing-impaired child. The child incorporates these reactions, which become a part of his self-concept.

Cull and Hardy (1974, p. 160) state that the hearing-impaired are much more like the hearing than they are different. The one notable difference is that they have suffered a psychological impact of a disability and have adjusted or are in the process of adjusting to this impact. This adjustment can cause problems in their social adjustment, but with understanding and additional help they can succeed.

Somatopsychology and self-concept

A new method for the study of the hearingimpaired is somatopsychology (Cull \& Hardy, 1974, p. 161). The basis for this is the body-image concept. The body image is a complex conceptualization which people use to describe themselves. This becomes one of the basic parts of the total personality and helps to determine the reaction to the environment.

Two aspects emerge from the body-image concept. They are the Ideal body image (desired body image) and 
the actual body image. The greater the congruity between these two images results in a better psychological adjustment for the individual; the greater the discrepancy between these two parts of the self-concept, the poorer the psychological adjustment (p. 162).

\section{Hearing-impaired self-concept} and school

Habbe $(1936$, p. 77) reports that personality maladjustments do not necessarily accompany real or imaGiñed organ deficiencies. If a hearing-impaired child's total adjustment to life is good, then minor difficulties can be resolved. Habbe also states that there is no need to consider a separate educational system for the hearing-impaired. Habbe's study concluded that the hearingimpaired belong in the same school as the hearing child.

Myklebust (1964, p. 176) concludes that hearingimpaired children, as all other children, present a wide variation of individual differences. Characteristic shifts in psychological structure and learning processes must be assumed. A carefully chosen program that uses the individual's total capacities allows the hearingimpaired to attain the maximum benefits from schooling. An important implication of Myklebust's study is that the effects of hearing-impairment are being modified in speelfic respects according to the type of school attended. It is apparent that through specialized methods, the 
hearing-impaired child can be assisted to actualize his potential more successfully.

Frick (1973, p. 46) reports that hearing-impaired children from st. Louis are successful in the public schools. Most of the children have some difficulties in the academic areas of math, literature, and general vocabulary. Almost all hearing-impaired children need to be taught to be more independent and more aware of acceptable social behavior. Another need they have is to be more conscious of the world around them. The ultimate goal is for all students to be given the opportunity to progress to the maximum of their ability.

Giangreco and Giangreco (1970, p. 7) stress the need for educating so that hearing-impairment is not an excuse for not succeeding or meeting life satisfactorily. If a person is educated as an individual, individual maturation helps to develop personal responsibility for self. With a good background in school, a person should be ready to accept responsibility and establish personal goals without needing a crutch for failure to do what is wanted or needed.

According to Croft (1974, p. 121), the most important result of comfortable anonymity in the classroom of a public school is the opportunity to be equal to one's peers and to have the chance to develop a strong, positive self-concept. Croft indicates that focusing 
attention on a handicap can retard maturity and later lead to a lonely existence. The mainstreaming experience in public school allows one to have a realistic selfknowledge and an accurate self-assessment of strengths and weaknesses. This is possible because the child is compared with the norm of the group.

Lerrman and Guifoyle (1970, p. 66) report that the vocational information and planning of hearing-impaired subjects is related to their language and communication competence, the level of stimulation available in their home, and, to a lesser degree, their intelligence and independence. This study suggests that existing programs of vocational training and orientation have little impact on the prevocational behavior. If there is an impact on the students, a concerted effort must be made to increase vocational information, change attitudes, and develop individual potentials at an earlier age. If this is not done, the hearing-impaired do not gain the professional status that is within the reach of their abilities. The hearing-impaired child should be encouraged to join the youth groups of the community and school (Cosper, 1971). This involvement helps to develop an adequate self-concept and makes the child more aware of society's demands. Socialization also helps to acquaint the hearing students with the problems of their hearingimpaired classmates and encourages an understanding of 
the problems that the hearing-impaired students must endure.

Despite the problems of the hearing-impaired individual, school helps to develop a social awareness. Rodda (1970) reports that there is a lasting impression that there is a "social viability of the hearing-impaired child including the profoundly hearing-impaired" (p. 156).

Adolescent stress and hearingimpaired self-concept

Moores (1978, p. 100) concludes that when a child in this culture enters adolescence, the possibility for role tension in the family increases. The strain is greatly intensified for the hearing-impaired child. Such a child may experience greater difficulty in establishing a personal position within the family structure and culture, and within society in general. It takes more understanding and patience to deal with the storm and stress of the hearing-impaired adolescent. All segments of society must shoulder a larger amount of responsibility for hearing-impaired adolescents than they would for the hearing adolescent. With this greater cooperation, the adolescent can safely thread a path through this time of trauma (p. 102).

However, to paint a completely depressing picture of the situation is wrong. Despite the problems that the hearing-impaired person must suffer, the majority make an 
adequate adjustment to the world. They marry, raise children, pay taxes, contribute to the good of the community and country, fight, watch television, and entertain themselves in much the same way as does every other person in the country. Most of their problems are the result of the dominant society. Hearing-impaired people survive and endure in the face of the indifferent world with which they must deal (Moores, p. 103).

\section{Bearing-impaired Education}

\section{Early beginnings}

As education entered the nineteenth century, the thoughts of leading educators settled more and more on the child instead of exclusively on the subject matter to be taught. One of the early leaders of this trend in the education of the hearing-impaired children was Johannas Baptist Graser (Bender, 1970, p. 130). He insisted that the great weakness of most of the aducation of the hearing-impaired was that it was too isolated and remote from the real world. Graser maintained that the older German method that used oral teaching was the best method for teaching the hearing-impaired (1970, p. 131). At first this idea was widely accepted with enthusiasm. Classes for hearing-impaired children were made a fart of the public school systems in the German states. The method ran into difficulty because there were not enough allowances made for the slower pace of the hearing-impaired 
children. The oral method of teaching the hearingimpaired spread throughout Europe. Many wealthy people created their own schools for the hearing-impaired. Most of the early leaders of the oral teaching method in the United States received their exposure to the method in England (1970, p. 150).

\section{The Bell family contribution}

The mother of Alexander Graham Bell suffered a partial loss of hearing after having scarlet fever in her youth (Bender, 1970, p. 152). After coming to Canada, Alexander Melville Graham, Graham's father, started a school for the preparation of teachers that would use the oral method to teach the hearing-impaired. While on a lecture tour to Massachusetts, he was encouraged to give some lectures at Sarah Fuller's school for the deaf. Because of other commitments, he suggested his son Alexander Graham Bell for the position (1970, p. 157). In 1872, Bell opened a school in Boston for teachers of the deaf. Alexander's plan was to make it an oral training school. However, the opposition from the major schools for the day, with their silent methods, made this an impossibility. Alexander changed the school to the School of Vocal Physiology or Elocution (Bender, 1970, p. 157). He continued to refine and develop the oral method of teaching to use when instructing his young students. 
With $\$ 200,000$ of the prize money he won for inventing the telephone, Bell established The Volta Bureau to increase knowledge relating to the deaf. In 1890, the American Association for Teaching Speech to the Deaf was established, largely through the efforts of Bell. This developed into a national organization of teachers and educators interested in oral instruction for the hearing-impaired. Bell was one of the first to advocate that hearing-impaired children should begin their learning of speech by imitating whole words with meaning.

\section{Oral versus silent methods}

Perhaps the best-known family in the education of the hearing-impaired by the silent method is the Gallaudet family. Throughout the nineteenth century the development of the silent method of teaching had been supported by the Gallaudet family (Bender, 1970, p. 162). The silent method of teaching was followed in many of the schools that had large numbers of students. Out of the controversy concerning the oral and the silent teaching of the deaf, a typical American compromise was developed. Many of the schools adopted what came to be known as the combined method, which made use of the best of both methods. The Gallaudet family supported this method, but Bell never wholeheartedly endorsed it (Bender, 1970, p. 164). 
Twentieth-century advances

In the twentieth century, physical sciences came to the aid of the hearing-impaired in a very different way. New discoveries enabled the detection of more residual hearing in most cases of hearing impairment than had been suspected. Electronics made it possible to exploit this residual hearing in many ways that had never been done before (Oyer \& Frankman, 1975, p. 1). Earlier diagnosis and scientific improvements in the instruments for testing hearing brought to light more and more residual hearing. New electronic amplification of sound made usable this residual hearing to a degree never before dreamed possible.

Emphasis was centered on the importance of early teaching and nursery classes. Auditory stimulation had a special place in the hearing-impaired child's environment and helped to keep the child conscious of hearing (Simmons, 1966, p. 203).

Rinesthetic sensation and vibration, contributing factors in vocalization, cañ be utilized successfully, but the deaf baby's vocalization must be kept going at all costs if these factors are to be of any benefit (Tracy, 1964, p. 485). The accepted philosophy now is that a child's hearing impairment should be discovered as early as possible, and that from that time on he or she should be kept immersed in a constant environment of oral 
language in the most effective ways that can be devised (Anation \& Reneu, 1968; Shore, 1964; Vorce, 1958). The child's first teachers are the child's parents. Centers for hearing-impaired children are developinq specific programs for counseling and training parents on how to begin the work of teaching communication skills to their babies. The general principle in such teaching is the use of a constant flow of normal, natural speech relating directly to the child's immediate family. The parents are cautioned to maintain patience and optimism through the inevitable, initial period of subtle absorption (Knox \& McDonnell, 1968; Miller, 1960; Tracy, 1964). Increasing recognition is being given to the importance of a normal speech and language atmosphere for the young hearing-impaired child. Many special classes in ordinary nursery-school settings are being held concurrently with the special hearing-impaired nursery schools. Normal-hearing children are being included in equal proportions with the hearing-impaired children (Weinstein, 1968).

As the public has become more aware of the need for an early beginning for the handicapped child, Congress has responded with laws that have given federal assistance to the initation and expansion of programs for the handicapped. Public Law 90-538, the Handicapped Children's Early Assistance Act, was signed into law by 
President Johnson on September 30, 1968 (Fellendorf, 1969, p. 78). This law was a major thrust forward in the area of helping the handicapped child. It has been heralded as an integral part of the total attack on the needs of the handicapped. The law provides a stimulus to the local school district to upgrade the quality of the education which is being provided to all handicapped children (Gallagher, 1968, p. 488). Federal funds have been made available to initiate and implement special programs at all age levels. Also there are programs organized under the Rehabilitation Service Administration to assist people in need of vocational training (Gallagher, 1968; Howe, 1968; Martin, 1968).

Many schools now offer updated programs in vocational training for young people who are hearing-impaired. One such is the National Technical Institute for the Deaf based at the Rochester Institute of Technology in New York. The course is planned for hearing-impaired highschool graduates. Many students, upon entering the school, find themselves unprepared for college in spite of their diplomas. The new program was started so these students could have success in college. The program offers instruction in areas needed or requested. The aim of the Institute is to provide broad career opportunities (Fellendorf, 1969, p. 298).

The modern trend towards mechanization has also 
invaded the elementary-school classroom. Teaching tools of many varieties are available. video tapes, tape recorders, overhead projectors, reading machines, and documentary films are just a few of the teaching tools that have been implemented in the classrooms of the hearing-impaired schools. In the hands of a skillful teacher, they can add a new dimension to the children's learning tasks; misused, they can waste the time of both the teacher and the students (Cunningham, 1969, p. 176). There are sincere efforts to develop cooperation and correlation between the various groups that work with the hearing-impaired. The National Association of Hearing and Speech Agencies has encouraged its local centers to make arrangements with local organizations of adult hearing-impaired to insure mutual benefits. Services offered would include training and rehabilitation of hearing-impaired adults for better job opportunities; development of rosters of hearing-impaired families for social contacts within the communities; encouragement of educational facilities for hearing-impaired children. With community cooperation, these can help to improve quality of life and the status of citizens who are hearing-impaired (Workshop on Community Services, 1969).

Direction of hearingimpaired education

The hearing-impaired child is now detected at an 
earlier age than ever before and the public is more concerned with the rehabilitation of these hearing-impaired children. Linguists have made important discoveries about the child's active participation in the evolvement of his own communication system.

However, the picture presented by the research in the area of hearing-impaired education is confused. Some of it is too esoteric to be of much value. Too often it only proves what the researcher sets out to find. Evaluation of the research and the methodology used in the education of the hearing-impaired must be more scientifically conducted if it is to provide a definite standard for future development. Cooperation among the various educational and social services that attempt to help the hearing-impaired can only improve the quality of services (Bender, 1970, p. 208).

\section{Summary}

Early writers have given the development of the self-concept an important place in their psychological writings. Formerly, writers equated ego development with that of self-concept. The later writers began to give the self-concept a new and individual place in psychological theories. They began to realize that the selfconcept is important to the development of the whole person. The self-concept is one of the important factors which controls a person's bchavior. The self-concept is 
important in the evaluation of others and the individual's reactions to them. The total person is in many respects greatly influenced by his or her self-concept. The individual self-concept goes through three stages of development. The first is the development of the self-concept through the parents' treatment of the child; the second is the child's perception of society's evaluation of his family, including himself; and the third is the child's accumulation of experiences with success and failure. At any age success in human relationships is just as vital as the experience with other kinds of achievement. The importance of the child's parents and the child's environment is vitally fundamental to the total development and especially to the child's self-concept. During the school years, the peer group evaluation of the individual assumes the preeminent position in the growth of the self-concept. Without the successful interaction with peers, the individual's self-concept either withers or retards the total development. The adult self-concept also needs constant positive reinforcement or periodical reinforcement. Without this, the effectiveness of the individual's work and interaction with others diminishes.

The measurcment of the self-concept is a difficult task for the psychologist. Most of the methods follow the psychometric approaches. This is due primarily 
to the lack of cohesiveness of the research in the field of self-concept. It has been difficult to develop a definition of self-concept that is universally accepted. One of the main problems with this is that the selfconcept is something that cannot be seen. However, the results of the self-concept in a person's behavior can be seen and measured. Most self-concept tests and research have measured this behavior. Two highly recommended tests in the field of self-concept research are the Tennessee Self-Concept Scale and the Piers-Harris Children's Self-Concept Scale. Because the Piers-Harris can be used with a wider grade range, it was selected as the instrument for this study.

The hearing-impaired person develops a selfconcept in the same sequence as the hearing person. The fundamental needs of the hearing-impaired individual are the same as those of the hearing person. The same three steps are traversed with the same importance in the development of the hearing-impaired individual's self-concept. One of the main differences is that the hearing-impaired may develop a secure self-concept more slowly and more patience has to be exercised by their teachers.

The educational evolution of the hearing-impaired started near the beginning of the nineteenth century. The Germans were the early leaders of the oral method of educating the hearing-impaired. The leader of the 
movement in this country was Alexander Graham Bell. Because his mother and wife were both hearing-impaired, he always had a strong interest in the oral education. The Gallaudet family were the leaders of the silent education of the hearing-impaired. About the turn of the century, a compromise between the two methods produced the total education method, but Bell never full accepted this compromise because he believed that the word should be learned in context with attached meaning.

During the 1960s, the federal government encouraged local school districts to develop programs for the hearing-impaired. This was done through legislation that provided for the least restrictive environment for the development and education of the hearing-impaired. The legislation has promoted cooperation between the local school districts and other local agencies that provide services for the hearing-impaired. 
CHAPTER III

\section{RESEARCH DESIGN}

This chapter describes the research design employed to measure the self-concept components and dimensions of the hearing-impaired students of the Berrien County Day Program for Hearing-Impaired and the hearing students of the Berrien Springs Public Schools. To make this comparison, an ex-post-facto research methodology was used (Campbell \& Stanley, 1963, pp. 70-71; Kerlinger, 1973, p. 9).

The Piers-Harris Children's Self-Concept Scale was chosen as the instrument for this study. All scores mentioned were obtained by using this instrument. A comparison of the self-concept components and dimensions of hearing-impaired students of the Berrien County Day Frogram for Hearing-Impaired and the hearing students of the Berrien Springs Public Schools is made by using ANOVAB (Futcher, 1980) This was used as a preliminary statistical analysis and was not reported in chapter IV. Six research factors of the self-concept are compared by using a differential analysis. The mean scores of the hearing-impaired students and the hearing students in 
each grade are compared by using a t-test. A t-test compares the mean score of the middle school for the hearingimpaired and the middle school hearing students. The high-school mean score for the hearing-impaired and the hearing students are compared by a t-test. Each grade or group is compared to the national mean as established by the Piers-Harris by using a t-test.

\section{Null Hypotheses}

The null hypotheses are tested at the .05 level for significance. The study examines the following null hypotheses.

1. There is no significant difference between the self-concept of the hearing-impaired students of the Berrien County Day Program for Hearing-Impaired and the hearing students of the Berrien Springs Public Schools.

2. There is no significant difference between the self-concept of the hearing-impaired students of the Berrien County Day Program for Hearing-Impaired and the national norm as established by the Piers-Harris Children's Self-Concept Scale.

3. There is no significant difference between the self-concept of the hearing students of the Berrien Springs Public Schools and the national norm as established by the PiersHarris Children's Self-Concept Scale. 


\section{Population for the Study}

The present study was concerned with two categories of students: the hearing-impaired students attending the Berrien County Day Program for Hearing-Impaired and the hearing students of the Berrien Springs Public Schools. The students of the Berrien County Day Program for Hearing-Impaired live with their parents and are bussed to the school from their homes in Berrien, Cass, and Van Buren counties of Michigan. The program for the hearing-impaired is the only hearing-impaired school in the three counties.

The total population of the Berrien County Day Program for Hearing-Impaired in grades six through twelve was used in the study. Students in the first five grades were not used because the director of the school felt that the language of the Piers-Harris would be too difficult for the students to accurately comprehend. The total population of grades six through eleven was used in this study. The twelfth grade students taking an English course were also ircluded.

\section{Instrumentation}

The instrument used in this study was the PiersHarris Children's Self-Concept Scale.

\section{Piers-Harris Children's Self-Concept Scale}

The Piers-Harris Children's Self-Concept Scale is a quickly administered (15-20 minutes) self-report 
instrument designed for use with a wide age range of children. Administered in a group, the Piers-Harris requires approximately third-grade reading ability. The Piers-Harris can be administered by responsible, educated non-psychologists, but should be interpreted only with the aid of someone knowledgeable in measurement and statistics, psychology of adjustment, and self-theory. The scale was designed primarily for research on the aevelopment of children's self-attitudes and correlates of the attitudes (Manual, Piers-Harris, 1969).

\section{Development of the scale}

The universe to be sampled in a children's selfconcept scale should consist of items reflecting the concerns that children have about themselves. An original pool of items was developed from Jersild's (1952) coilection of children's statements about what they liked and disliked about themselves (Piers-Harris, 1964). Jersild grouped these into the following categories: (a) physical characteristics and appearance; (b) clothing and grooming; (c) health and physical soundness; (d) home and family; (e) enjoyment of recreation; (f) ability in sports; ( $g$ ) ability in school, attitudes toward school, etc.; (h) intellectual abilities; (i) special talents (music, art); (j) just me, myself; and (k) personality, character, inner resources, and emotional tendencies. The pilot study established that the children 
understood the items and that the inventory could be completed in thirty to thirty-five minutes. Following the administration, items answered in one direction fewer than 10 percent or more than 90 percent of the time were inspected and in most cases dropped. One hundred forty items remained (Manual, Piers-Harris, 1969).

The one-hundred-forty-item scale was administered to different grades in a large school system. In the elementary grades, classes were chosen from several differert schools representing a cross section of the socioeconomic levels in the community. In the high school, slow, average, and bright students participated. After sample testing and revision, one hundred items remained. Later these were reduced to the present eighty of the scale (Manual, Piers-Harris, 1969).

\section{Validity}

An attempt was made to build content validity into the scale by defining the universe to be measured about which the children reported qualities they liked or disliked about themselves (Jersild, 1952). Items of the scale were designed to cover all of these areas. During the item analysis, nondiscriminating items were dropped so that the final scale no longer covers every area to the same degree. The factor analysis indicated that factors from the remaining items cut across the original Jersild categories and reflect an emphasis on the 
last two groups, i.e., "just me, myself" and "personality, character, inner resources, emotional tendencies." These are a better reflection of a child's self-concept than the narrow categories such as "enjoyment of recreation" or "special talents" (Manual, Piers-Harris, 1969).

Reliability

Buro's Seventh Mental Measurements Yearbook (1971) contains a detailed and favorable review of the Piers-Harris Children's Self-Concept Scale. The review considered the scale to possess adequate reliability and validity for research use.

Wylie (1974) reviewed several instruments for testing children and considered the Piers-Harris Children's Self-Concept Scale to be the most promising research tool available.

In another major review, Measures of Social psychological Attitudes by Robinson and Shaver (1973), PiersHarris Children's Self-Concept Scale is the most highly recommended scale for children.

Most of the reliability data in the manual comes from the 1969 standardization study. This data ranges from coefficients of .93 to .77 . Piers-Harris (1969) used the Kuder-Richardson Formula 21 to judge the homogeneity of the test. The resulting coefficients range from .78 to .93. To further check the reliability, the SpearmanBrown odd-even formula was applied and gave results of 
.90 and .87 . A retest on one-half the standardization sample after four months resulted in coefficients of .72, .71, and .77. These were judged satisfactory for a personality instrument.

\section{Administration}

The Piers-Harris Scale takes only fifteen to twenty minutes to administer but there is no time limit for the students taking the test. Before administering the test, the examiner discussed the value of the students finding out how they felt about themselves. The administrator read the instructions aloud to the students and the students proceeded to answer the items (Manual, Piers-Harris, 1969).

\section{Scoring}

In this study the scales were scored by the computiig center at Andrews University. This has given consistent results for each of the students. The computer printouts have also given the different factors for the scale.

\section{Procedure}

During the first half of September 1980, the principals of the Berrien Springs High School and the Berrien Springs Middle School were contacted and their permission to test the students was secured. Both were 
very cooperative and interested in the results to be obtained. The director of the Berrien County Day Program for Hearing-Impaired had given his permission on June 16,1980 .

On September 15, 1980, the researcher, with the help of the English teachers, administered the PiersHarris Children's Self-Concept Scale to all students in the Berrien Springs Middle School and the Berrien Springs High School English classes. On the same day the hearingimpaired students were given the Piers-Harris Children's Self-Concept Scale by the teachers in the hearingimpaired classrooms.

The class teachers administered the scale to their respective students since this is the least threatening situation for the students. Also the teachers were the most familiar with the language abilities of the students and could give them help where it was needed.

The students' scales were then sent to the computer at Andrews University for scoring. The results were further analyzed by the researcher using the computer at Andrews University.

\section{Summary}

This chapter presented the research methodology and described the type of research, the population, the research design, and the instrument. The research design 
procedures were described and the statistical analysis to test the null hypotheses were indicated. The next chapter will present and analyze the data. 


\section{CHAPTER IV}

\section{PRESENTATION AND ANALYSIS OF DATA}

This chapter presents and analyzes the data on 926 hearing-impaired and hearing students. The chapter is divided into three main sections. The first section presents the data of the study and includes subjective impressions. The second analyzes the data by testing the hypotheses. The final section compares the six major factors of the Piers-Harris Children's Self-Concept Scale for each grade and school.

\section{Presentation of the Data}

The data is presented in three sections. The first section is an introduction, which gives information about the participants involved and the reliability of the test instrument. Eight tables list the means of the self-concept in the second section. The third gives the means of the total self-concept of the schools and compares them to the national norm as established by the Piers-Harris Children's Self-Concept Scale.

\section{Participants}

For the present study, the Piers-Harris Children's 
Self-Concept Scale was administered to 926 students of the Berrien County Day Program for Hearing-Impaired and the Berrien Springs Public Schools. Two of the hearingimpaired students were not tested because their physical handicap is not hearing related. Of the 926 tested, sixty-nine were hearing-impaired and 857 had normal hearing. The 926 tests were entered into the computer to build a data bank for the present study. The results were given to the schools involved in November 1980 . Counselors at the respective schools used the results to aid in the counseling of the students. Table I gives the percentages of middle-school students by grade and the percentages of hearing-impaired students and students with normal hearing within each grade. Table 2 shows the percentages of high-school students by grade and the percentages of hearing-impaired students and students with normal hearing in each grade. Table 3 indicates the percentages of the total school population tested and percentages of students with hearing impairment or with normal hearing within each school. Tests were entered into the computer by the researcher and statistical analyses were done by computer personnel.

Group and grade means

The grade norms from the Piers-Harris Children's Self-Concept Scale for the hearing-impaired and the normal-hearing students are presented in a series of six 
tables (tables 4-9). The group means from the Piers-

Harris Children's Self-Concept Scale for the middle school for the hearing-impaired and the normal-hearing students are presented in tables 10 and 11.

TABLE 1

PERCENTAGES OF MIDDLE-SCYOOL STUDENTS TESTED

\begin{tabular}{lccc}
\hline Grade & $\begin{array}{c}\text { Number } \\
\text { of } \\
\text { students }\end{array}$ & $\begin{array}{c}\text { Percent- } \\
\text { age of } \\
\text { grade }\end{array}$ & $\begin{array}{c}\text { Percent- } \\
\text { age of } \\
\text { school }\end{array}$ \\
\hline Sixth hearing-impaired & 11 & 7.5 & 2.5 \\
Sixth normal-hearing & 136 & 92.5 & 30.3 \\
$\begin{array}{l}\text { Seventh hearing-impaired } \\
\text { Seventh normal-hearing }\end{array}$ & 145 & 99.3 & 0.2 \\
$\begin{array}{l}\text { Eighth hearing-impaired } \\
\text { Eighth normal-hearing }\end{array}$ & 14 & 10.0 & 32.3 \\
$\begin{array}{l}\text { Total number of } \\
\text { students testec }\end{array}$ & 448 & 90.0 & 3.3 \\
\hline
\end{tabular}

The assumption of homogeneity of variance for the sixth grade is upheld. Therefore a t-test is used. With 145 degrees of freedom, $t$ is -.1884 and probability is .851 on $a$ two-tailed test.

The seventh-grade normal-hearing and hearingimpaired students are not compared since only one hearingimpaired student was enrolled in the seventh grade. A $t$-test cannot be used with only one student because this would give zero degrees of freedom. 
TABLE 2

PERCENTAGE OF HIGH-SCHOOL STUDENTS TESTED

\begin{tabular}{lrrr}
\hline \multicolumn{1}{c}{ Grade } & $\begin{array}{c}\text { Number } \\
\text { of } \\
\text { students }\end{array}$ & $\begin{array}{r}\text { Percent- } \\
\text { age of } \\
\text { grade }\end{array}$ & $\begin{array}{r}\text { Percent- } \\
\text { age of } \\
\text { school }\end{array}$ \\
\hline Ninth hearing-impaired & 22 & 15.1 & 4.6 \\
Ninth normal-hearing & 123 & 84.9 & 25.7 \\
Tenth hearing-impaired & 10 & 6.8 & 2.1 \\
Tenth normal-hearing & 136 & 93.2 & 28.5 \\
Eleventh hearing-impaired & 6 & 4.6 & 1.3 \\
Eleventh normal-hearing & 125 & 95.4 & 26.1 \\
Twelfth hearing-impaired & 4 & 7.1 & 0.8 \\
Twelfth normal-hearing & 52 & 92.9 & 10.9 \\
$\begin{array}{l}\text { Total number of } \\
\text { students tested }\end{array}$ & 478 & & 100.0 \\
\hline
\end{tabular}

TABLE 3

PERCENTAGE OF TOTAL SCHOOL STUDENTS TESTED

\begin{tabular}{lccc}
\hline \multicolumn{1}{c}{ Grade } & $\begin{array}{c}\text { Number } \\
\text { of } \\
\text { students }\end{array}$ & $\begin{array}{c}\text { Percentage } \\
\text { of } \\
\text { school }\end{array}$ & $\begin{array}{c}\text { Percentage } \\
\text { of total } \\
\text { school }\end{array}$ \\
\hline $\begin{array}{l}\text { Middle school } \\
\text { hearing-impaired }\end{array}$ & 27 & 6.0 & 2.9 \\
$\begin{array}{l}\text { Middle school } \\
\text { normal-hearing }\end{array}$ & 421 & 94.0 & 45.5 \\
$\begin{array}{l}\text { High school } \\
\text { hearing-impaired }\end{array}$ & 42 & 8.8 & 4.5 \\
$\begin{array}{l}\text { High school } \\
\text { normal-hearing } \\
\text { Total number of } \\
\text { students tested }\end{array}$ & $\underline{436}$ & 91.2 & $\underline{47.1}$ \\
\hline
\end{tabular}


TABLE 4

SIXTH GRFDE MEANS ON PIERS-HARRIS

CHILDREN'S SELF-CONCEPT SCALE

\begin{tabular}{ccc}
\hline \hline Students & Means & $\begin{array}{r}\text { Number of } \\
\text { students }\end{array}$ \\
\hline Normal-hearing & 53.4044 & 136 \\
Hearing-impaired & 54.0909 & 11 \\
\hline
\end{tabular}

The assumption of homogeneity of variance for the eighth grade (table 5) is not upheld. Therefore the Welch procedure is used with degrees of freedom correct to the lower integer. The Welch procedure corrects the statistical test when there is an uneven distribution of scores.

TABLE 5

EIGHTH GRADE MEANS ON PIERS-HARRIS CHILDREN'S SELF-CONCEPT SCALE

\begin{tabular}{lcc}
\hline Students & Means & $\begin{array}{r}\text { Number of } \\
\text { students }\end{array}$ \\
\hline Normal-hearing & 55.2571 & 140 \\
Hearing-impaired & 55.4000 & 15 \\
\hline
\end{tabular}

The assumption of homogeneity of variance for the ninth grade (table 6 ) is upheld. Therefore a t-test is used. With 143 degrees of freedom, $t$ is .3799 and 
probability is .705 on a two-tailed test.

TABLE 6

NINTH GRADE MEANS ON PIERS-HARRIS

CHILDREN'S SELF-CONCEPT SCALE

\begin{tabular}{ccc}
\hline \hline Students & Means & $\begin{array}{r}\text { Number of } \\
\text { students }\end{array}$ \\
Normal-hearing & 57.0975 & 123 \\
Hearing-impaired & 56.0909 & 22 \\
\hline
\end{tabular}

The assumption of homogeneity of variance for the tenth grade (table 7) is upheld. Therefore a t-test is used. With 144 degrees of freedom, $t$ is .5601 and probability is .567 on a two-tailed test.

TABLE 7

TENTH GRADE MEANS ON PIERS-HARRIS

CHILDREN'S SELF-CONCEPT SCALE

\begin{tabular}{ccc}
\hline Students & Means & $\begin{array}{r}\text { Number of } \\
\text { students }\end{array}$ \\
\hline Normal-hearing & 55.5147 & 136 \\
Hearing-impaired & 53.6000 & 10 \\
\hline
\end{tabular}

The assumption of homogeneity of variance for the eleventh grade is upheld. Thercfore a t-test is used. With 129 degrees of freedom, $t$ is .0709 and probability is .944 on a two-tailed test. 
TABLE 8

ELEVENTH GRADE MEANS ON PIERS-HARRIS

CHILDREN'S SELF-CONCEPT SCALE

\begin{tabular}{ccc}
\hline Students & Means & $\begin{array}{r}\text { Number of } \\
\text { students }\end{array}$ \\
\hline Normal-hearing & 56.6720 & 125 \\
Hearing-impaired & 56.3333 & 6 \\
\hline
\end{tabular}

The assumption of homogeneity of variance for the twelfth grade (table 9) is upheld. Therefore a t-test is used. With 54 degrees of freedom, $t$ is 1.3872 and probability is .171 on a two-tailed test.

TABLE 9

TWELFTH GRADE MEANS ON PIERS-HARRIS

CHIIDREN'S SELF-CONCEPT SCALE

\begin{tabular}{ccc}
\hline \hline Students & Means & $\begin{array}{r}\text { Number of } \\
\text { students }\end{array}$ \\
\hline Normal-hearing & 59.7888 & 52 \\
Hearing-impaired & 51.7500 & 4 \\
\hline
\end{tabular}

The assumption of homogeneity of variance for the middle school students is upheld (table 10). Therefore a $t$-test is used. With 446 degrees of freedom, $t$ is -.3931 and probability is .694 on a two-tailed test. 
TABLE 10

TOTAL MIDDLE SCHOOL MEANS ON PIERS-HARRIS CHILDREN'S SELF-CONCEPT SCALE

\begin{tabular}{lcc}
\hline Students & Means & $\begin{array}{r}\text { Number of } \\
\text { students }\end{array}$ \\
\hline Normal-hearing & 54.2233 & 421 \\
Hearing-impaired & 55.1481 & 27 \\
\hline
\end{tabular}

The assumption of homogeneity of variance for the high school students is upheld (table 11). Therefore a t-test is used. With 476 degrees of freedom, $t$ is .9377 and probability is .349 on a two-tailed test.

TABLE 11

TOTAL HIGH SCHOOL MEANS ON PIERS-HARRIS CHILDREN'S SELF-CONCEPT SCALE

\begin{tabular}{ccc}
\hline Students & Means & $\begin{array}{r}\text { Number of } \\
\text { students }\end{array}$ \\
\hline Normal-hearing & 56.8027 & 436 \\
Hearing-impaired & 55.1190 & 42 \\
\hline
\end{tabular}

Comparison of grade, group, and national means

The grade, group, and national means are compared in this section. Each mean is compared to the national mean by using a t-test. Comparisons are shown in tables 12 and 13. 
TABLE 12

COMPARISON OF GRADE MEANS AND NATIONAL MEAN USING A $t$-TEST

\begin{tabular}{|c|c|c|}
\hline Grade & $t$ & $\begin{array}{l}\text { Probability on } \\
\text { Two-tailed test }\end{array}$ \\
\hline Sixth normal-hearing & .0712 & .943 \\
\hline Sixth hearing-impaired & .2191 & .831 \\
\hline Seventh normal-hearing & .6701 & .504 \\
\hline \multicolumn{3}{|l|}{ Seventh hearing-impaired* } \\
\hline Eighth normal-hearing & 1.8147 & .072 \\
\hline Eighth hearing-impaired & 1.1993 & .250 \\
\hline Ninth normal-hearing & 3.6226 & .000 \\
\hline Ninth hearing-impaired & 1.1775 & .252 \\
\hline Tenth normal-hearing & 2.4150 & .017 \\
\hline Tenth hearing-impaired & .0960 & .926 \\
\hline Eleventh normal-hearing & 3.2990 & .001 \\
\hline Eleventh hearing-impaired & .5267 & .621 \\
\hline Twelfth normal-hearing & 4.1085 & .000 \\
\hline Twelfth hearing-impaired & -.3992 & .716 \\
\hline
\end{tabular}

*Degrees of freedom less than one; test not made.

Table 14 compares boys and girls of the various grades to determine if there is a difference in the mean self-concepts of the sexes.

Table 15 compares all boys and girls of the middle school and the high school to determine if there is a 
difference between the mean self-concept scores for the two groups.

TABLE 13

COMPARISON OF GROUP MEANS AND NATIONAL

MEAN USING A t-TEST

\begin{tabular}{|c|c|c|}
\hline Group & $t$ & $\begin{array}{l}\text { Probabil :ty on } \\
\text { Two-tailed test }\end{array}$ \\
\hline $\begin{array}{l}\text { Middle school (grades } 6,7,8 \text { ) } \\
\text { normal-hearing }\end{array}$ & 1.5197 & .129 \\
\hline $\begin{array}{l}\text { Middle school (grades } 6,7,8 \text { ) } \\
\text { hearing-impaired }\end{array}$ & 1.0716 & .294 \\
\hline $\begin{array}{c}\text { High school (grades } 9,10, \\
11,12) \text { normal-hearing }\end{array}$ & 6.4837 & .000 \\
\hline $\begin{array}{l}\text { Aigh school (grades } 9,10, \\
11,12) \text { hearing-impaired }\end{array}$ & 1.1061 & .275 \\
\hline $\begin{array}{c}\text { All students in middle } \\
\text { and high school }\end{array}$ & 5.7350 & .000 \\
\hline
\end{tabular}

Testing the Hypotheses

This section analyzes the data by testing the hypotheses of the study.

The first hypothesis is concerned with the diference between the hearing-impaired and the normalhearing students. Table 16 indicates the $t$ score for each grade, the middle school, and the high school. The results of the t-tests show that there is no significant difference between the self-concept of the hearingimpaired and the self-concept of the normal-hearing 
students. The seventh-grade hearing-impaired and the normal-hearing students are not compared because there is only one seventh-grade hearing-impaired student. The test results confirm the research hypothesis that there is no significant difference between the self-concept of the hearing-impaired students and the normal-hearing students.

TABLE 14

COMPARISON OF BOYS' AND GIRLS'

MEANS FOR EACH GRADE

\begin{tabular}{lcc}
\hline \multicolumn{1}{c}{ Grade } & $t$ & $\begin{array}{c}\text { Probability on } \\
\text { Two-tailed test }\end{array}$ \\
\hline Sixth & -.5099 & .611 \\
Seventh & 1.8044 & .073 \\
Eighth & -.3976 & .691 \\
Ninth & 2.6777 & .008 \\
Tenth & .3050 & .761 \\
Eleventh & 1.6730 & .097 \\
Twelfth & 1.0789 & .285 \\
\hline
\end{tabular}

TABLE 15

COMPARISON OF BOYS' AND GIRLS'

MEANS FOR EACH SCHOOL

\begin{tabular}{lcc}
\hline Group & $t$ & $\begin{array}{c}\text { Probability on } \\
\text { Two-tailed test }\end{array}$ \\
\hline Middle school (grades 6,7,8) & .5284 & .597 \\
High school (grades 9,10,11,12) & 2.7483 & .006 \\
\hline
\end{tabular}


TABLE 16

COMPARISON OF MEANS OF HEARING-IMPAIRED

AND NORMAL-HEARING STUDENTS

\begin{tabular}{lcccc}
\hline \multicolumn{1}{c}{$\begin{array}{c}\text { Grade } \\
\text { or } \\
\text { group }\end{array}$} & $t$ & $\begin{array}{c}\text { Proba- } \\
\text { bility }\end{array}$ & $\begin{array}{c}\text { Degrees } \\
\text { of } \\
\text { freedom }\end{array}$ & $\begin{array}{c}\text { Signifi- } \\
\text { cant .05 } \\
\text { level }\end{array}$ \\
\hline Sixth & -.1884 & .851 & 145 & no \\
Seventh & - & - & - & - \\
Eighth & -.0706 & .944 & 134 & no \\
Ninth & .3799 & .705 & 143 & no \\
Tenth & .5600 & .576 & 144 & no \\
Eleventh & .0709 & .994 & 129 & no \\
Twelfth & 1.3872 & .171 & 54 & no \\
Middle school & -.3931 & .694 & 446 & no \\
High school & .9377 & .349 & 476 & \\
\hline
\end{tabular}

The second hypothesis concerns the difference between the self-concept of the hearing-impaired students and the national norm as established by the Piers-Harris Children's Self-Concept Scale. The seventh-grade hearingimpaired student is not compared to the national norm because a $t$-test cannot be used with only one student. The results show that there is no significant difference between the self-concept of the hearing-impaired students and the national norm as established by the Piers-Harris Children's Self-Concept Scale (table 17). These results confirm the research hypothesis that there is no 
significant difference between the self-concept of the hearing-impaired students and the national norm as established by the Piers-Harris Children's Self-Concept Scale.

TABLE 17

COMPARISON OF MEANS OF HEARING-IMFAIRED STUDENTS AND THE NATIONAL MEAN

\begin{tabular}{lcccc}
\hline $\begin{array}{c}\text { Grade } \\
\text { or } \\
\text { group }\end{array}$ & $t$ & $\begin{array}{c}\text { Proba- } \\
\text { bility }\end{array}$ & $\begin{array}{c}\text { Degrees } \\
\text { of } \\
\text { freedom }\end{array}$ & $\begin{array}{c}\text { Signifi- } \\
\text { cant 05 } \\
\text { level }\end{array}$ \\
\hline Sixth & .0712 & .943 & .10 & no \\
Seventh & - & - & - & - \\
Eighth & 1.1193 & .250 & 14 & no \\
Ninth & 1.1775 & .252 & 21 & no \\
Tenth & .0960 & .926 & 9 & no \\
Eleventh & .5267 & .621 & 5 & no \\
Twelfth & -.3993 & .716 & 3 & no \\
Middle school & 1.0716 & .294 & 26 & no \\
High school & 1.1061 & .275 & 41 & \\
\hline
\end{tabular}

The third hypothesis is concerned with the difference between the self-concept of the normal-hearing students and the national norm as established by the Piers-Harris Children's Self-Concept Scale. The results of the t-tests that compare the means are given in table 18. The results of the t-tests show that there is a 
significant difference for grades nine, ten, eleven, and twelve. There is a significant difference between the mean of the high-school normal-hearing students and the national norm. However, there is no significant difference for the sixth, seventh, or eighth grades or the middle school when the results are compared to the national norm. The research hypothesis is upheld for the sixth, seventh, and eighth grades and the middle school. At the same time, it is rejected for the ninth, tenth, eleventh, and twelfth grades and the total high school.

TABLE 18

COMPARISON OF MEANS OF NORMAL-HEARING STUDENTS AND THE NATIONAL MEAN

\begin{tabular}{lcccc}
\hline $\begin{array}{c}\text { Grade } \\
\text { or } \\
\text { group }\end{array}$ & $t$ & $\begin{array}{c}\text { Proba- } \\
\text { bility }\end{array}$ & $\begin{array}{c}\text { Degrees } \\
\text { of } \\
\text { freedom }\end{array}$ & $\begin{array}{c}\text { Signifi- } \\
\text { cant 05 } \\
\text { level }\end{array}$ \\
\hline Sixth & .0712 & .943 & 135 & no \\
Seventh & .6701 & .504 & 144 & no \\
Eighth & 1.8147 & .072 & 130 & no \\
Ninth & 3.6226 & .000 & 122 & yes \\
Tenth & 2.4150 & .017 & 135 & yes \\
Eleventh & 3.2990 & .001 & 124 & yes \\
Twelfth & 4.1085 & .000 & 51 & yes \\
Middle school & 1.5197 & .294 & 420 & no \\
High school & 5.7350 & .000 & 435 & yes \\
\hline
\end{tabular}




\section{Self-Concept Factors}

A discriminant analysis is used to compare the six factors that have been extracted from the PiersHarris Children's Self-Concept Scale. Tables 18-28 compare the factors of the hearing-impaired students to those of the hearing students. Because there is only one seventh grade hearing-impaired student, the seventh grade will not be compared.

With six degrees of freedom and a probability of .0953, discriminant function one and following are not significant. These results would indicate that there is no significant difference between the sixth-grade hearingimpaired and hearing students as measured on the factors of the Piers-Harris Children's Self-Concept Scale (table 19).

TABLE 19

COMPARISON OF FACTORS FOR SIXTH GRADE

\begin{tabular}{lc}
\hline \multicolumn{1}{c}{ Factor } & $\begin{array}{c}\text { Standard discriminant } \\
\text { function }\end{array}$ \\
\hline Behavior & -10.6848 \\
Intellectual and school status & -5.3916 \\
Physical appearance and & $-9-3781$ \\
attitudes & 4.8159 \\
Anxiety & -3.5301 \\
Happiness and satisfaction & 21.4123 \\
\hline
\end{tabular}


The eighth-grade hearing students have a mean 4.207 while the hearing-impaired students have a mean of 1.128. With six degrees of freedom and a probability of less than .005 , the results of discriminant function one are significant (table 20).

TABLE 20

COMPARISON OF FACTORS FOR EIGHTH GRADE

\begin{tabular}{lc}
\hline \multicolumn{1}{c}{ Factor } & $\begin{array}{c}\text { Standard discriminant } \\
\text { function }\end{array}$ \\
\hline Behavior & 11.2621 \\
Intellectual and school status & $-7-5794$ \\
$\begin{array}{l}\text { Physical appearance and } \\
\text { attitudes }\end{array}$ & -24.2084 \\
Anxiety & -.0381 \\
Popularity & 7.9072 \\
Happiness and satisfaction & 14.0640 \\
\hline
\end{tabular}

Compared to the hearing-impaired students of the eighth grade, the eighth-grade hearing students tend to have a lower self-concept with regard to physical appearance, but a higher self-concept with regard to happiness and satisfaction and behavior (table 21).

The ninth-grade hearing students have a mean of 3.309 while the ninth-grade hearing-impaired have a mean of 7.10. With six degrees of freedom and a probability of less than .0005 , the results of the discriminant 
Eunction are significant (table 22).

TABLE 21

COMPARISON OF THE DISCRIMINANT FUNCTION IN EIGHTH-GRADE HEARING AND HEARING-IMPAIRED

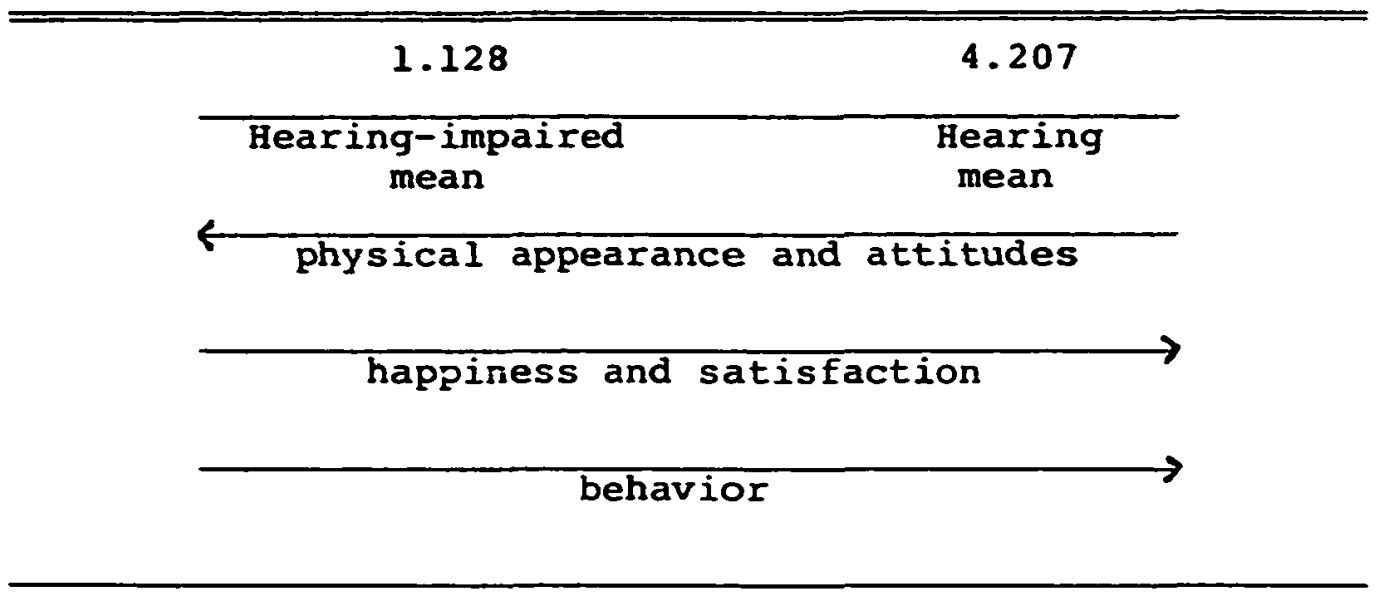

TABLE 22

COMPARISON OF FACTORS FOR NINTH GRADE

\begin{tabular}{lc}
\hline \multicolumn{1}{c}{ Factor } & $\begin{array}{c}\text { Standard discriminant } \\
\text { function }\end{array}$ \\
\hline Behavior & 2.9850 \\
Intellectual and school status & 1.8566 \\
$\begin{array}{l}\text { Physical appearance and } \\
\text { attitudes }\end{array}$ & -18.0626 \\
Anxiety & -.0381 \\
Popularity & 7.9072 \\
Happiness and satisfaction & 18.2471 \\
\hline
\end{tabular}


Compared to the ninth-grade hearing-impaired students, the ninth-grade hearing students have a higher self-concept with regard to happiness and satisfaction, but a lower self-concept with regard to physical appearance (table 23).

TABLE 23

COMPARISON OF THE DISCRIMINANT FUNCTION IN THE NINTH-GRADE HEARING AND HEARING-IMPAIRED

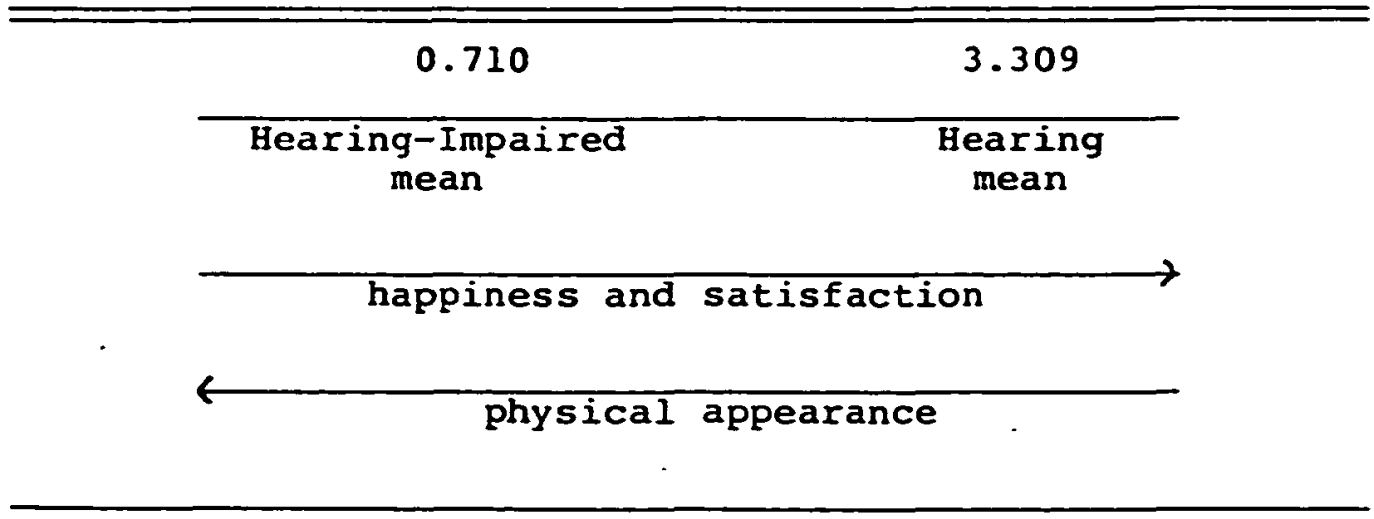

With six degrees of freedom and a probability of 9250, discriminant functions one and following for the tenth grade are not significant (table 24). These results indicate that there is no significant difference between the hearing-impaired students and normal-hearing students as measured on the factors of the Piers-Harris Children's Self-Concept Scale.

With six degrees of freedom and a probability of .0768, discriminant functions one and following for the eleventh grade are not significant (table 25). These results indicate that there is no significant difference 
between the hearing-impaired and hearing students as measured on the factors of the Piers-Harris Children's SelfConcept Scale.

TABLE 24

COMPARISON OF FACTORS IN TENTH GRADE

\begin{tabular}{lc}
\hline \multicolumn{1}{c}{ Factors } & $\begin{array}{c}\text { Standard discriminant } \\
\text { function }\end{array}$ \\
\hline Behavior & -7.4348 \\
Intellectual and school status & -18.0799 \\
Physical appearance and & \\
$\quad$ attitudes & 1.0238 \\
Anxiety & -7.9389 \\
Popularity & 26.4698 \\
Happiness and satisfaction & 3.5657 \\
\hline
\end{tabular}

TABLE 25

COMPARISON OF FACTORS IN THE ELEVENTH GRADE

Factors

Standard discriminant function

Behavior

3.6210

Intellectual and school status

4.0491

Physical appearance and

$-8.003$ attitudes

$-4.4671$

Anxiety

$-5.3229$

Popularity

11.5792

Happiness and satisfaction 
With six degrees of freedom and a probability of .0768 , discriminant functions one and following for the twelfth grade are not significant (table 26). These results indicate that there is not a significant difference between the hearing-impaired and hearing students as measured on the factors of the Piers-Harris Children's Self-Corcept Scale.

TABLE 26

COMPARISON OF THE FACTORS IN THE TWELFTH GRADE

Factors

Behavior

Intellectual and school status

Physical appearance and attitudes

Anxiety

Popularity

Happiness and satisfaction
Standard discriminant function

3.6210

4.0491

$-8.0003$

$-4.4671$

$-5.3229$

11.5792

The middle-school hearing students have a mean of 1.633, while the middle-school hearing-impaired students have a mean of -1.054 (table 27). With six degrees of freedom and a probability of less than .0002, the results of discriminant function one for the middle school are significant. 
TABLE 27

COMPARISON OF FACTORS OF THE MIDDLE SC,HCOI.

Factors

Behavior

Intellectual and scisol status

Physical appearance and attitudes

Anxiety

Popularity

Happiness and satisfaction standard discriminant function

$-18.3515$

$-37.9904$

3.4639

8.3793

29.4854

Compared to the hearing-impaired students of the middle school, the hearing students of the middle schooi tend to have a lower self-concept with regard to physical appearance and attitudes, but a higher self-concept with regard to happiness and satisfaction (table 28). Intellectual and school status are included because of their slight influence. Compared to the hearing-impaired students of the middle school, the hearing students of the middle school tend to have a lower self-concept with regard to intellectual and school status.

With six degrees of freedom and a probability of .5761, discriminant function one for the high school are not significant (table 29). These results indicate that there is no significant difference between the 
hearing-impaired and the hearing students of the high school as measured on the factors of the Piers-Harris Children's Self-Concept Scale.

TABLE 29

COMPARISON OF DISCRIMINANT FUNCTION IN MIDDLE-SCHOOL GEARING AND HEARING-IMPAIRED

\begin{tabular}{|c|c|}
\hline-1.054 & 1.633 \\
\hline $\begin{array}{l}\text { Hearing-impaired } \\
\text { mean }\end{array}$ & $\begin{array}{l}\text { Hearing } \\
\text { mean }\end{array}$ \\
\hline \multicolumn{2}{|c|}{$\leftarrow$ physical appearance and attitudes } \\
\hline \multicolumn{2}{|c|}{ happiness and satisfaction } \\
\hline intellectual & tatus \\
\hline
\end{tabular}

TABLE 29

COMPARISON OF FACTORS OF THE HIGH SCHOOI

\begin{tabular}{lc}
\hline \multicolumn{1}{c}{ Factors } & $\begin{array}{c}\text { Standard discriminant } \\
\text { function }\end{array}$ \\
\hline Behavior & 4.9630 \\
$\begin{array}{l}\text { Intellectual and school status } \\
\text { Physical appearance and } \\
\text { attitudes }\end{array}$ & -5.5535 \\
Anxiety & -30.8367 \\
Popularity & -8.2187 \\
Happiness and satisfaction & -6.4920 \\
\hline
\end{tabular}


The hearing students have a mean of 1.4616 while the hearing-impaired students have a mean of -.315 (table 30). With six degrees of freedom and a probability of less than .005 , the results of the discriminant function are significant.

TABLE 30

COMPARISON OF FACTORS FOR ALL STUDENTS

\begin{tabular}{lc}
\hline \multicolumn{1}{c}{ Factors } & $\begin{array}{c}\text { Standard discriminant } \\
\text { function }\end{array}$ \\
\hline Behavior & -4.2813 \\
Intellectual and school status & -3.4324 \\
$\begin{array}{l}\text { Physical appearance and } \\
\text { attitudes }\end{array}$ & -47.0113 \\
Anxiety & -7.6371 \\
Popularity & 8.0573 \\
Happiness and satisfaction & 47.8738 \\
\hline
\end{tabular}

TABLE 31

COMPARISON OF DISCRIMINANT FUNCTION OF ALL STUDENTS IN MIDDLE SCHOOL AND HIGH SCHOOL

\begin{tabular}{cc}
\hline-.315 & 1.416 \\
\cline { 2 - 3 } & $\begin{array}{c}\text { Hearing } \\
\text { mean } \\
\text { mean }\end{array}$ \\
${ } }$
\end{tabular}


91

Compared to the hearing-impaired students of the midale school and the high school, the hearing students of the middle school and the high school tend to have a higher self-concept with regard to happiness and satisfaction, but a lower self-concept with regard to physical appearance and attitude (table 31). 


\section{CHAPTER V}

\section{SUMMARY, CONCLUSIONS, AND RECOMMENDATIONS}

The summary, conclusions, and recommendations of the study are presented in this chapter. The rationale of the study stemmed from the supposition that hearingimpaired students of the Berrien County Day Program for Hearing-Impaired have developed a self-concept that is as adequate as the self-concept of the hearing students of the Berrien Springs Public Schools.

\section{Summary}

The summary of this study is divided into the following sections: (1) purpose; (2) overview of related literature; (3) population, delimitation, and instrumentation; and (4) results.

\section{Purpose}

Because it is hypothesized that there is no significant difference between the self-concept of the hearing-impaired and the hearing students, the purpose of this study was to compare the self-concepts of these two groups. Another consideration was to compare the selfconcept factors named by the Piers-Harris Children's SelfConcept scale. The self-concept factors named by the 
Piers-Harris Children's Self-Cnncept Scale were analyzed for the hearing-impaired and hearing students.

Overview of related literature

Early writers have given the development of the self-concept an important place in their psychological writings. Formerly, writers equated ego development with that of self-concept. Later writers began to give the self-concept a new and individual place in psychological theories. They began to realize that the self-concept is important to the development of the whole person. It is one of the important factors which controls a person's behavior and is important in the evaluation of others and in one's actions to them. The total person is in many respects greatly influenced by self-concept.

The individual's self-concept goes through three stages of development. The first is the development of the self-concept through the parents' treatment of the child; the second is the child's perception of society's evaluation of the child's family, including himself or herself; and the third is the child's accumulation of experiences with success and failure. At any age, success in human relationships is just as vital as the experience with other kinds of achievement. The importance of the child's parents and individual environment is clearly fundamental to the total development and especially to the child's self-concept. During the school 
years, the peer-group evaluation of the individual assumes the preeminent position in the growth of the self-concept. Without the successful interaction with peers, the individual's self-concept withers and retards the total development. The adult self-concept also needs constant positive reinforcement or periodical reinforcement. Without this, the effectiveness of the individual's work and interaction with others diminish in quality.

Measurement of the self-concept is a difficult task for the psychologist. Most of the methods follow the psychometric methods. Much of the difficulty is due to the lack of cohesiveness of the research in the field of self-concept. It seems almost impossible to develop a definition of self-concept that is universally accepted. One of the main problems is that self-concept is something that cannot be seen. However, the results of the self-concept as it controls a person's behavior can be seen and measured. Most self-concept tests and research have measured this resultant behavior. Two highly recommented tests in the field of self-concept research are the Tennessee Self-Concept Scale and the Piers-Harris Children's Self-Concept Scale. Because the Piers-Harris can be used with a wider age range, it was selected as the instrument for this study.

The hearing-impaired person develops a selfconcept in the same sequence as does the hearing person. 
The fundamental needs of the hearing-impaired are the same as those of the hearing person. The same three steps in the development of a self-concept are traversed by the hearing-impaired as by those with normal hearing. One of the main differences is that the hearing-impaired may develop a secure self-concept more slowly and therefore more patience needs to be exercised when dealing with the hearing-impaired.

The educational evolution of the hearing-impaired began about the beginning of the nineteenth century. The Germans were the early leaders of the oral method for the hearing-impaired. The leader of this movement in the United States was Alexander Graham Bell. Because his mother and his wife were both hearing-impaired, Bell always had a strong interest in the oral education of the hearing-impairea. The Gallaudet family were the leaders of the silent education of the hearing-impaired. About the beginning of this century a compromise between the two methods produced the total-education method. Bell never fully accepted this because he believed that the language should be learned using words in context with attached meaning.

During the 1960s, the federal government encouraged the local school districts to develop programs for the hearing-impaired. This was done through legislation that provided for the least restrictive environment for 
the development and education of the hearing-impaired.

The legislation has promoted cooperation between the local school districts and other local agencies that provide services for the hearing-impaired.

\section{Population}

The population for this study was composed of sixty-nine hearing-i.apaired students of the Berrien County Day Program for Hearing-Impaired and 857 students of the Berrien Springs Public Schools. From the sixth through twelfth grade, all hearing-impaired and hearing students taking English were tested. The hearing-impaired students were from the Michigan counties of Berrien, Cass, and Van Buren. The hearing students all lived in the Berrien Springs public-school district.

\section{Delimitation}

The results of this study were limited to the students of the Berrien Springs Public Schools and the Berrien County Day Program for Hearing-Impaired. The results were further limited to the students in grades six through twelve.

\section{Instrumentation}

Because of the nature of the language difficulties of the hearing-impaired, the Piers-Harris Children's Self-Concept Scale was used for this study. The PiersHarris requires only a third-grade reading ability, 
therefore the language was not a barrier to a more accurate result from each student. The items of the PiersHarris could be explained to the students if there were difficulties with the language.

\section{Results and discussion}

The results of the study regarding the hypotheses are discussed in this section. Each hypothsis is accepted or rejected according to the test of significance. To test the hypotheses, alpha was set at the .05 level.

Hypothesis 1. There is no significant difference between the self-corcept of the hearing-impaired students of the Berrien County Day Program for ilearing-Impaired and the hearing students of the Berrien Springs Public Schools.

On the basis of the data obtained for the hearingimpaired and the hearing students, the hypothesis is accepted. Three comparisons were made: (1) hearing and hearing-impaired self-concept means for each grade, (2) hearing and hearing-impaired means for the middle school, and (3) hearing and hearing-impaired means for the high school. The conclusion is that there is no significant difference between the self-concept means for the hearing and hearing-impaired students. This finding is in accordance with the research reviewed in the study of the literature (Myklebust, 1950; Cuii and Hardy, 1974 ; and Moores, 1978). 
Bypothesis 2. There is no significant difference between the self-concc $=t=5$ tho hearing-impaired students of the Berrien County Day Program for Hearing-Impaired and the national norm as established by the Piers-Harris Children's Self-Concept Scale.

On the basis of data obtained for the hearingimpaired, the hypothesis is accepted. Three comparisons were made: (1) hearing-impaired self-concept means for each grade were compared with the national norm, (2) hearing-impaired self-concept means for the middle school with the national norm, and (3) hearing-impaired self-concept means for the high school with the national norm. The conclusion is that there is no significant difference between the self-concept for the hearingimpaired and the national norm as established by the Piers-Harris Children's Self-Concept Scale. This is in accordance with the research cited under hypothesis one. Bypothesis 3. There is no significant difference between the self-concept of the hearing students of the Berrien Springs Public Schools and the national norm as established by the Piers-Harris Children's Self-Concept Scale.

On the basis of the data obtained for the hearing students, the hypothesis is accepted for the midale school and rejected for the high school. Three comparisons were made: (1) hearing students' self-concept 
means for each grade with the national norm, (2) hearing students' self-concept means for the middle school with the national norm, and (3) hearing student's self-concept mean for the high school with the national norm. The conclusion is that there is no significant difference between the self-concept of the hearing students of the middle school and the national norm as established by the Piers-Harris Children's Self-Concept Scale. However, there is a significant difference between the normalhearing and the national norm as established by the Piers-Harris Children's Self-Concept Scale.

The Piers-Harris Children's Self-Concept Scale has six factors that have been identified for research purposes. These factors are: (1) behavior, (2) intellectual and school status, (3) physical appearance, (4) anxiety, (5) popularity, and (6) happiness and satisfaction. These factors count for 42 percent of the variance in the total self-concept score. The test is constructed so that the higher the factor score, the more positive the attribute. For example, the higher the score of the anxiety factor, the lower the anxiety of the individual. The discriminant analyses of these factors are included because of their interest. However, the factor scores are not to be overly generalized. As Piers and Harris state, "the factors are only indicators and should form the basis of further research and study." 
The results of the discriminant analyses are commented on only if they are significant. If there are no significant results for a grade or group, no comment is given.

Compared to the eighth-grade hearing-impaired students, the eighth-grade hearing students tend to have a lower self-concept with regard to physical appearance. However, eighth-grade hearing students tend to have a higher self-concept than the eighth-grade hearing-impaired with regard to happiness and satisfaction and behavior. Compared to the ninth-grade hearing-impaired students, the ninth-grade hearing students tend to have a lower self-concept with regard to physical appearance. At the same time, the ninth-grade hearing students tend to have a higher self-concept than the ninth-grade hearing-impaired with regard to happiness and satisfaction.

Compared to the middle-school hearing-impaired student, the middle-school hearing students tend to have a higher self-concept with regard to happiness and satisfaction. The hearing-impaired tend to have a higher selfconcept than the middle-school hearing students with regard to physical appearance and attitudes. Also, the middle-school hearing students tend to have a slightly lower self-concept with regard to intellectual and school status than do the middle-school hearing-impaired students. 
101

Compared to the high-school hearing-impaired students, the high-school hearing students tiend to have a higher self-concept with regard to happiness and satisfaction. The high-school hearing students tend to have a higher self-concept than the high-school hearing-impaired students with regard to physical appearance and attitude.

\section{Conclusions}

From the foregoing findings, the following conclusions are made:

1. The hearing-impaired students, when their mean self-concept scores are compared, have self-concepts that are not significantly different from the national norm or mean as established by the Piers-Harris Children's Self-Concept Scale.

2. The hearing-impaired students, when their mean self-concept scores are compared, have self-concepts that are not significantly different from those of the hearing students.

3. The middle school hearing students, when their mean self-concept scores are compared, have selfconcepts that are not significantly different from the national norm or mean as established by the piers-Harris Children's Self-Concept Scale.

4. The high-school hearing students, when their means are compared, have self-concepts that are significantly different from the national norm or mean as 
established by the Piers-Harris Children's Self-Concept Scale. However, according to the manual of the PiersHarris Children's Self-Concept Scale, they are both well within the normal range. In practical use, this would not be a significant difference (Piers-Harris, 1969).

5. The eighth- and ninth-grade hearing students tend to have a higher self-concept with regard to happiness and satisfaction than the hearing-impaired students of the eighth and ninth grades.

6. The eighth- and ninth-grade hearing-impaired students tend to have a higher self-concept with regard to physical appearance than the hearing students of the eighth and ninth grades.

7. The high-school hearing students tend to have a higher self-concept with regard to happiness and satisfaction and physical appearance and attitude than the hea-ing-impaired students of the high school.

8. The hearing students and the hearing-impaired students have many self-concept factors that are very similar.

\section{Recommendations}

As the study progressed, questions were raised that were not part of the present research. Consequently, the following recommendations for further research are proposed :

1. The teaching methods of the Berrien County 
Day Program for Hearing-Impaired should be compared to those of similar schools to determine if this could be a factor in the development of the self-concept of the hearing-impaired students.

2. A replication study should include the state school for the hearing-impaired. This would allow the researcher to compare the self-concept of the hearingimpaired living with their parents and the hearingimpaired students living at the state school.

3. A state-wide study that includes similar hearing-impaired schools could provide a more in-depth study of the total hearing-impaired self-concept.

4. An instrument that would more adequately measure self-concept would greatly improve the objectivity of the research. The Piers-Harris Children's Self-Concept Scale is one of the best that is available, but with some of the older groups, it has some questions that are too juvenile.

5. Experimental studies should be undertaken to determine if the type of home has an influence on the student's self-concept.

6. A better definition of self-concept and a better understanding of its components would enable a researcher to more accurately formulate a research study. 7. A study of the parents and their treatment of the hearing-impaired child may shed additional informa- 
tion as to the best environment for the development of a child with a hearing impairment.

8. An investigation of the social self-concept of the hearing-impaired child should be a longitudinal study that would trace the progress over the period of the school years.

9. A comparison of the treatment of the hearingimpaired child as compared to the treatment of the hearing child by teachers may give valuable information as to the development of the self-concept.

10. A comparison of the social self-concept of the hearing-impaired with that of the hearing child could produce information as to the development of a social life for the adult.

11. A replication of the study should include the self-concept of the parents to determine if the hearingimpaired child merely develops a self-concept that is the same as that of his parents or if there is a deviation in self-concept from that of his parents. 
APPENDIX A

THE PIERS-HARRIS CHILDREN'S SELF-CONCEPT SCALE 
PLEASE NOTE:

Copyrighted materials in this document have not been filmed at the request of the author. They are available for consultation, however, in the author's university library.

These consist of pages:

106-111

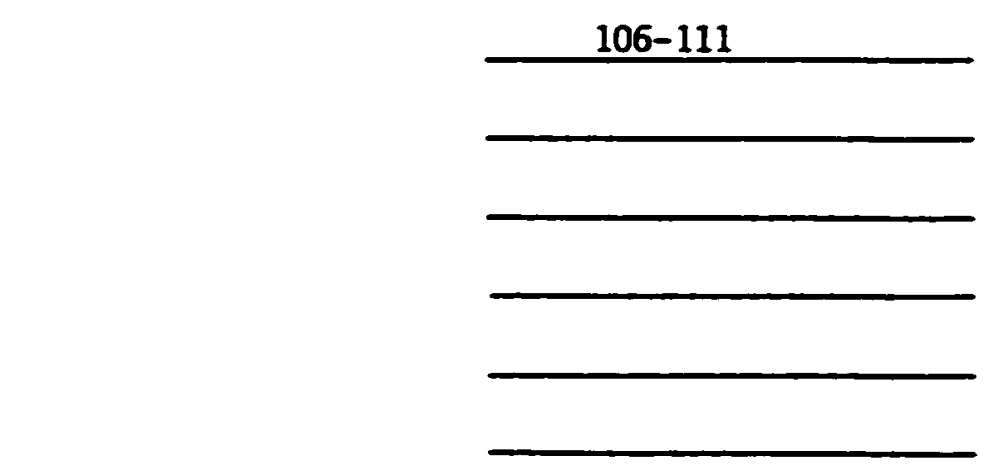

University

Microfilms

International

300 N ZEEB RO.. ANN ARBOR. MI 4810613131761.4700 
APPENDIX B

TEST RESULTS OF THE PIERS-HARRIS

CHILDREN'S SELF-CONCEPT SCALE 


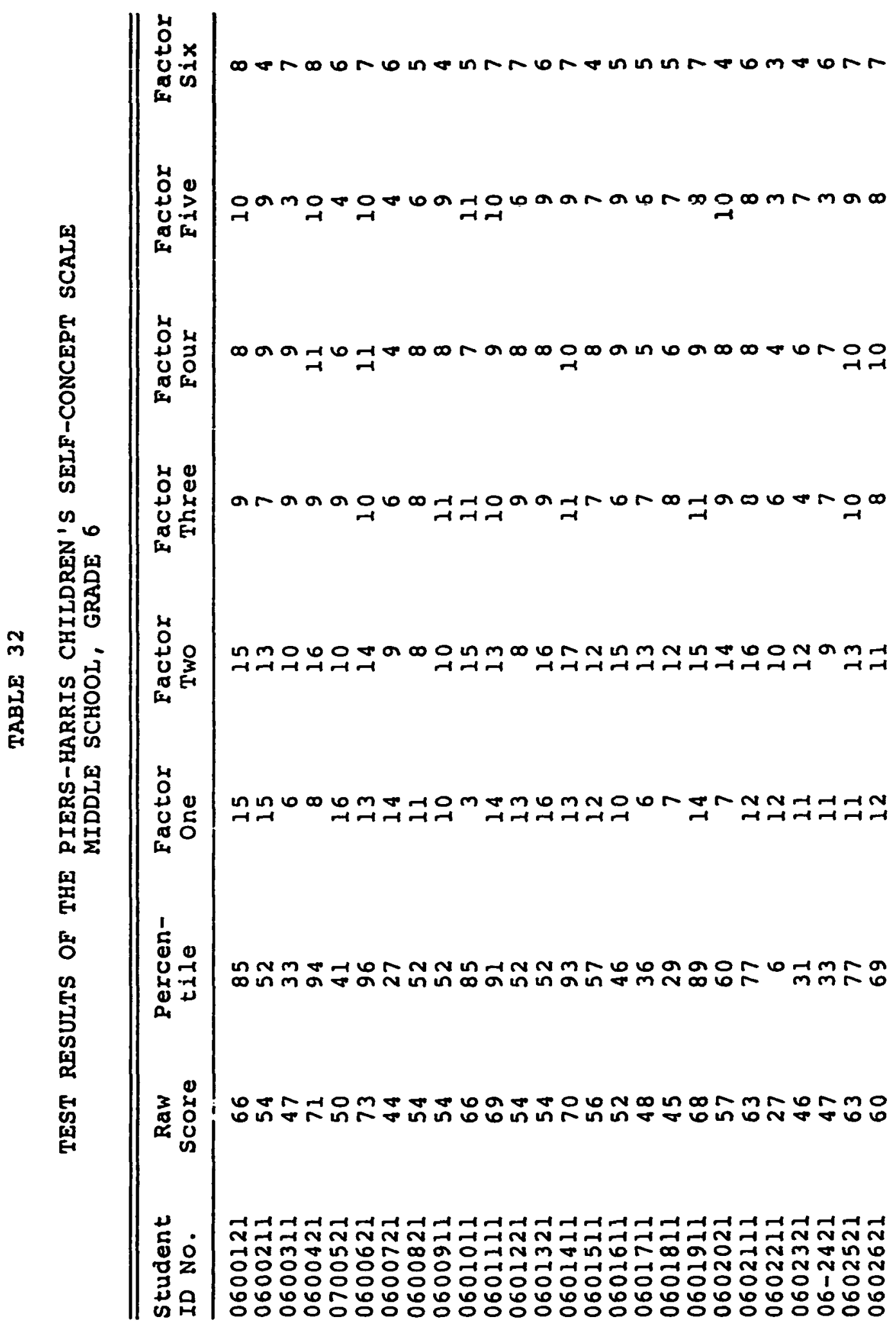




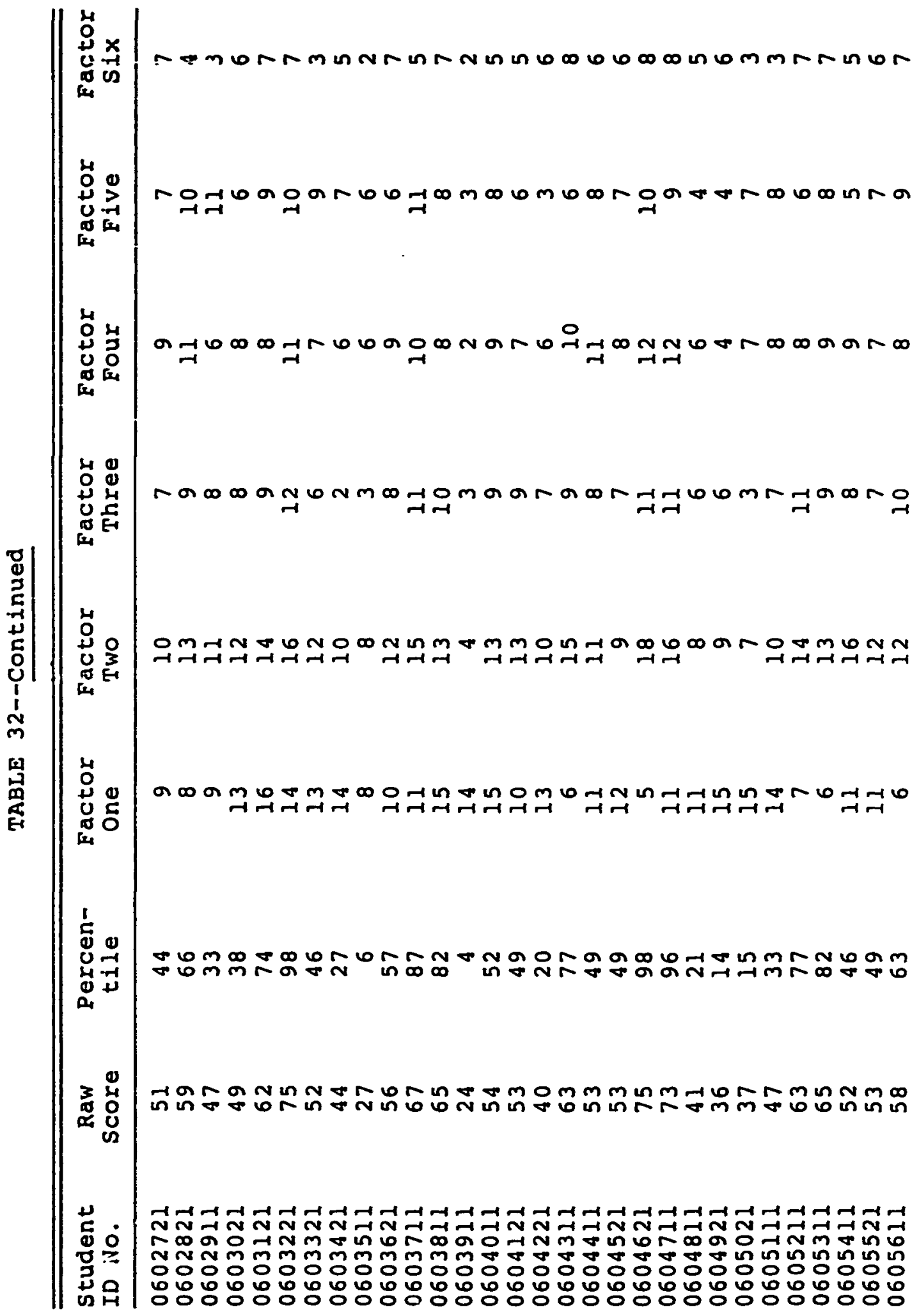




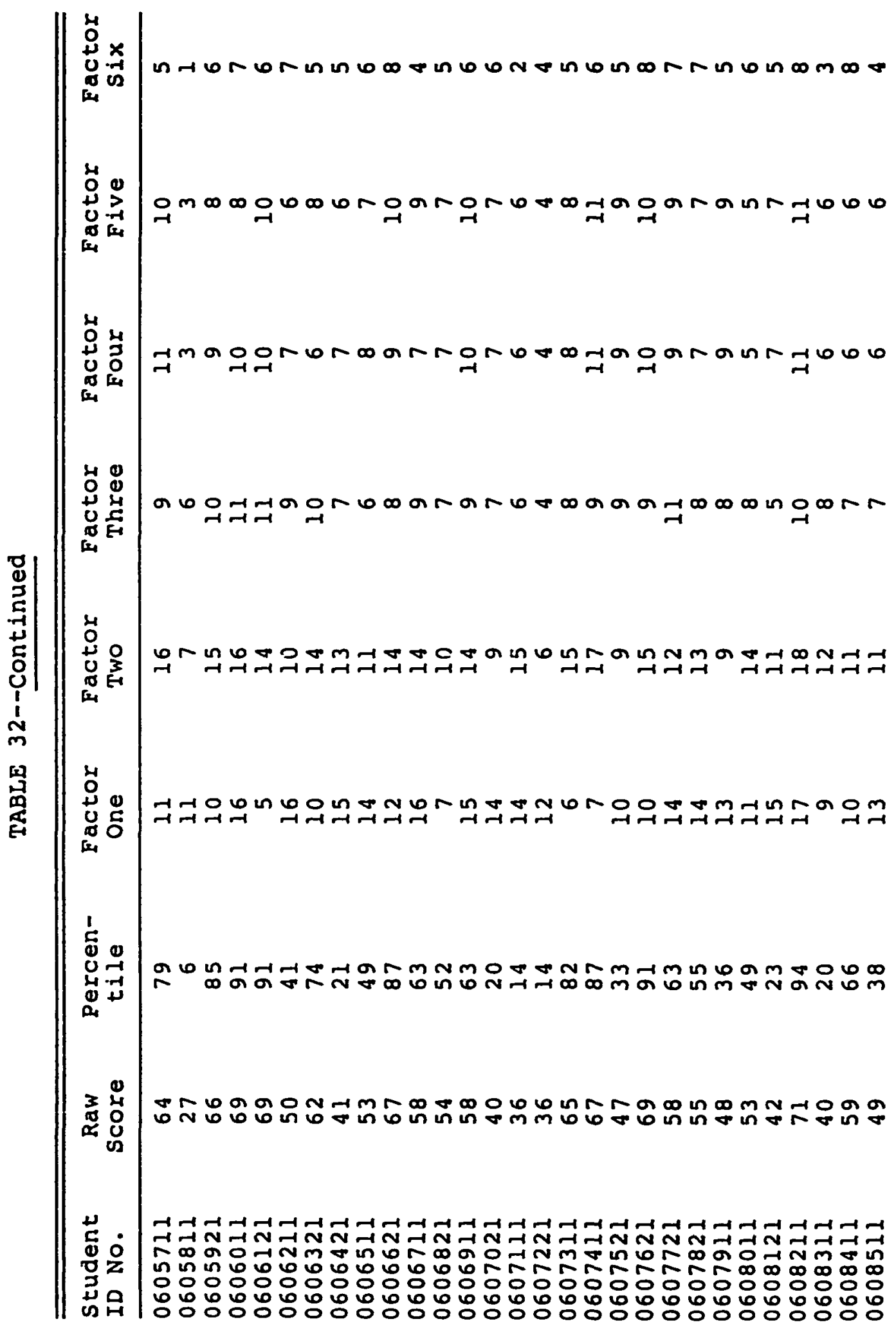




$$
9
$$




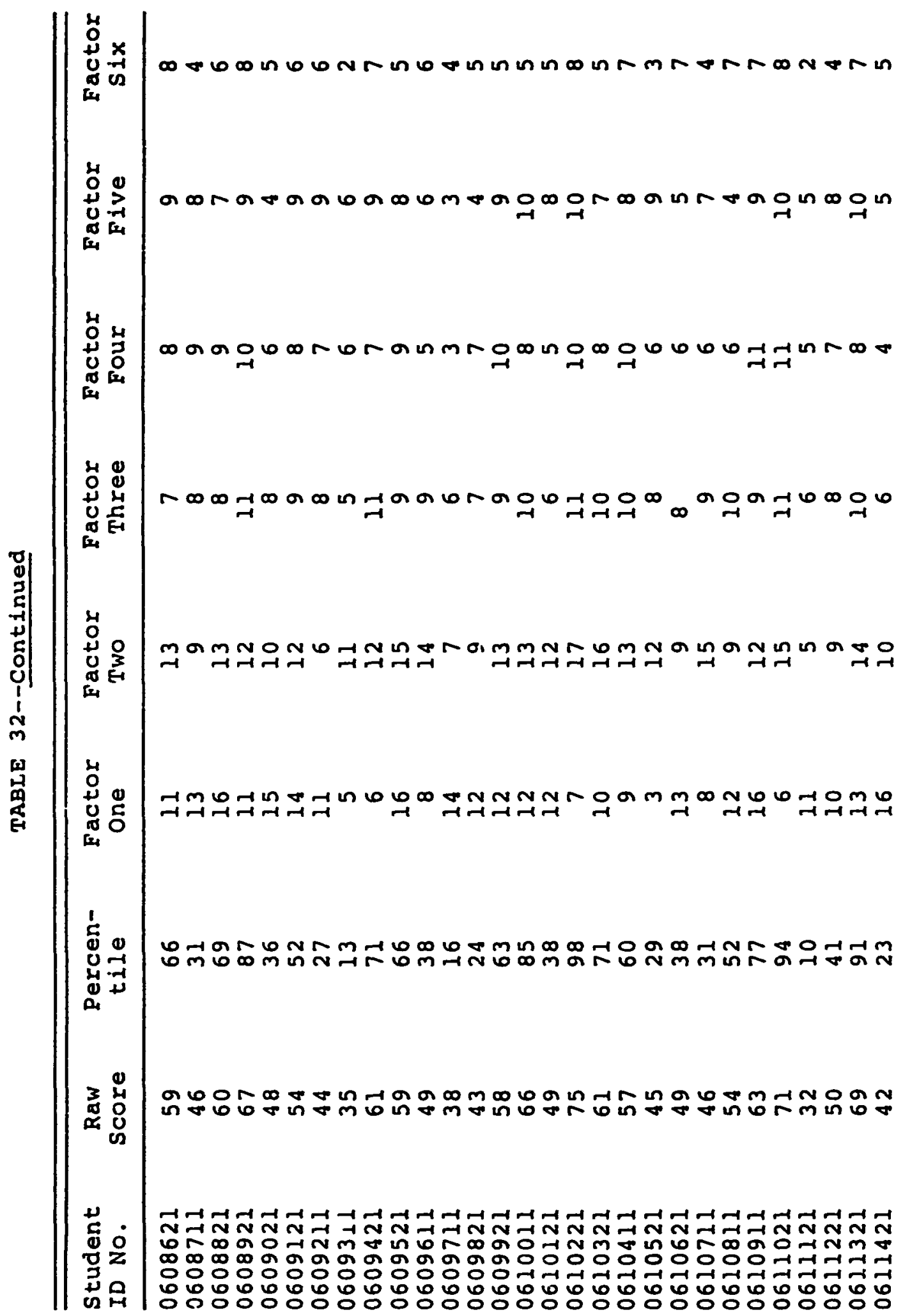




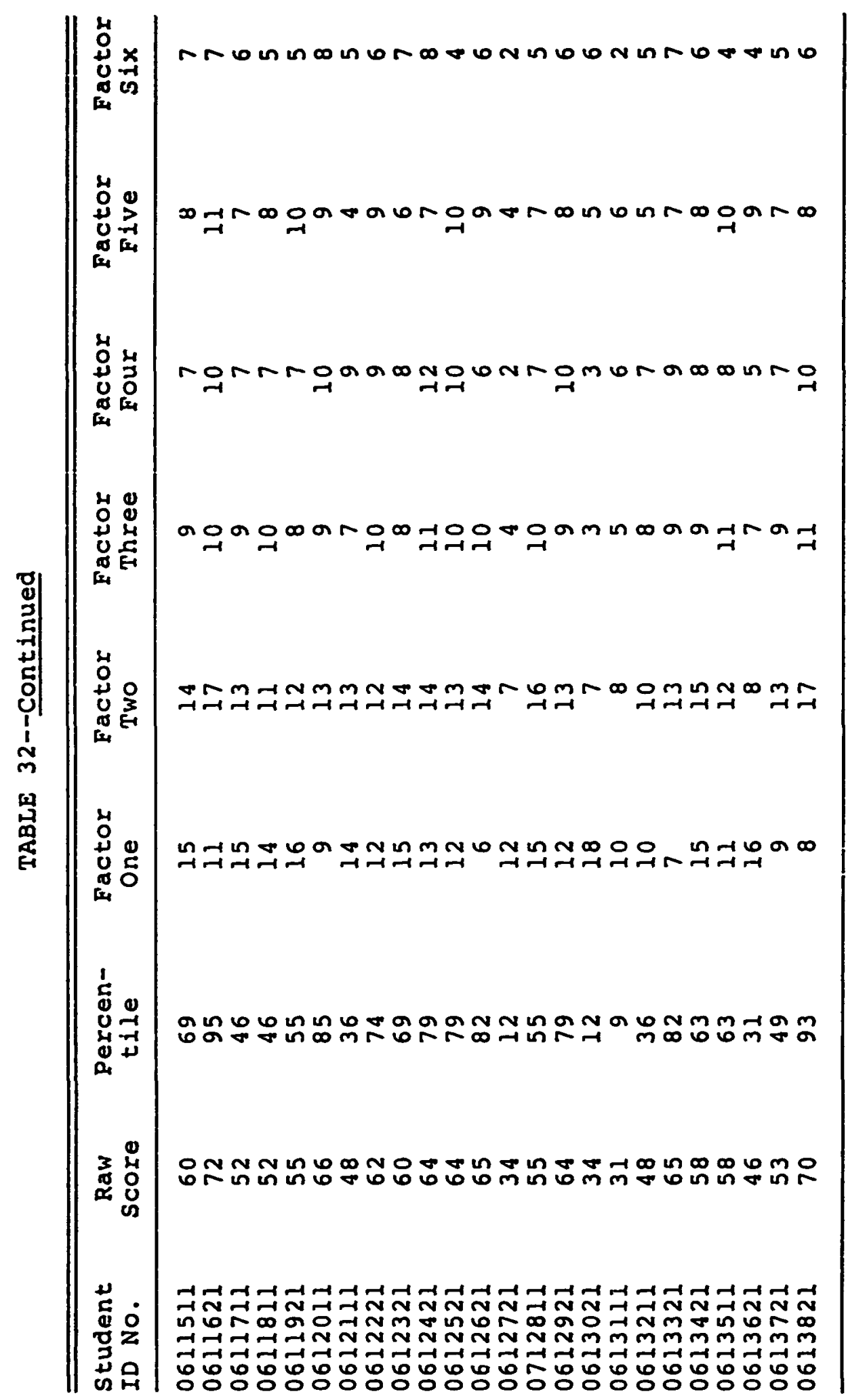




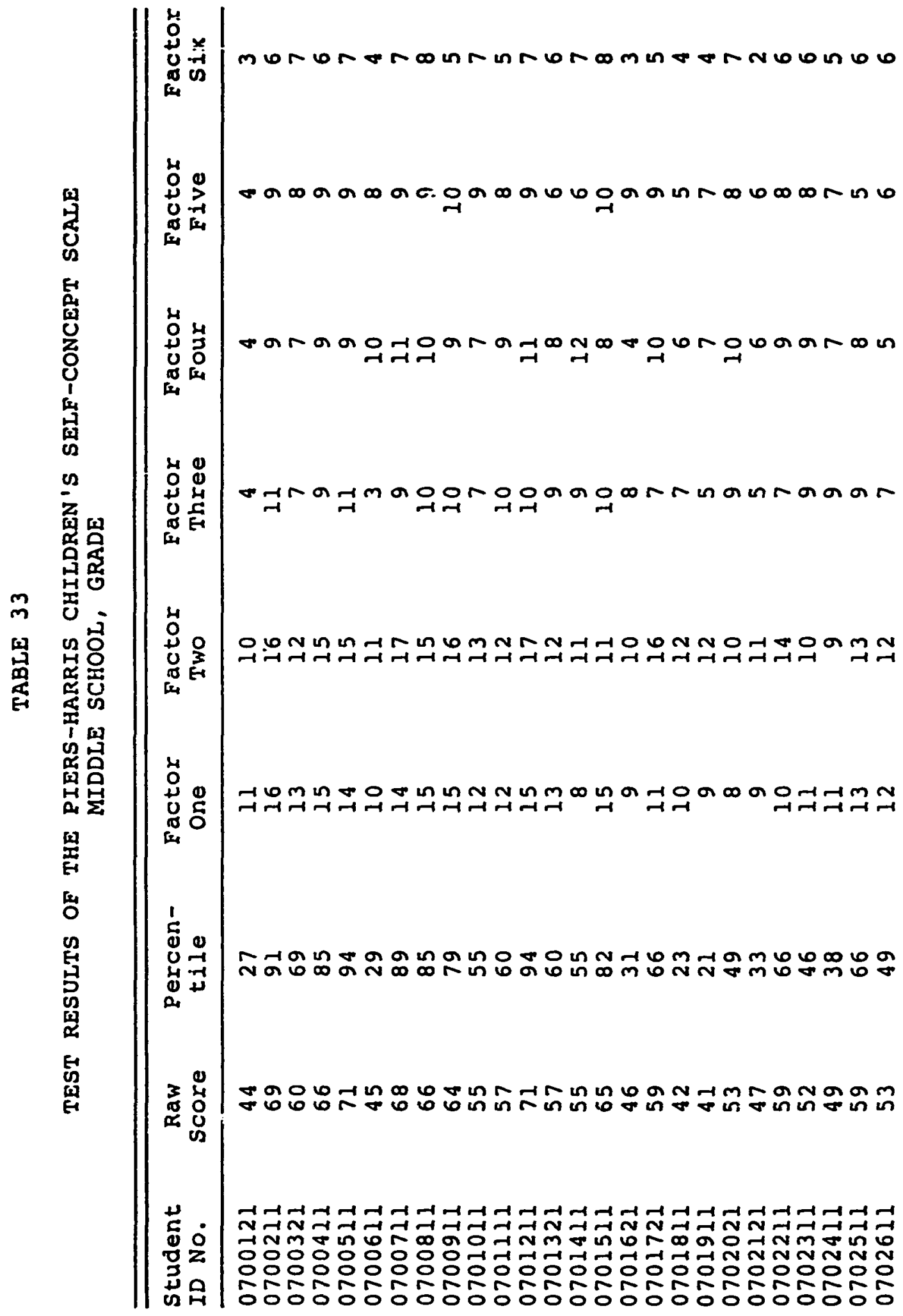




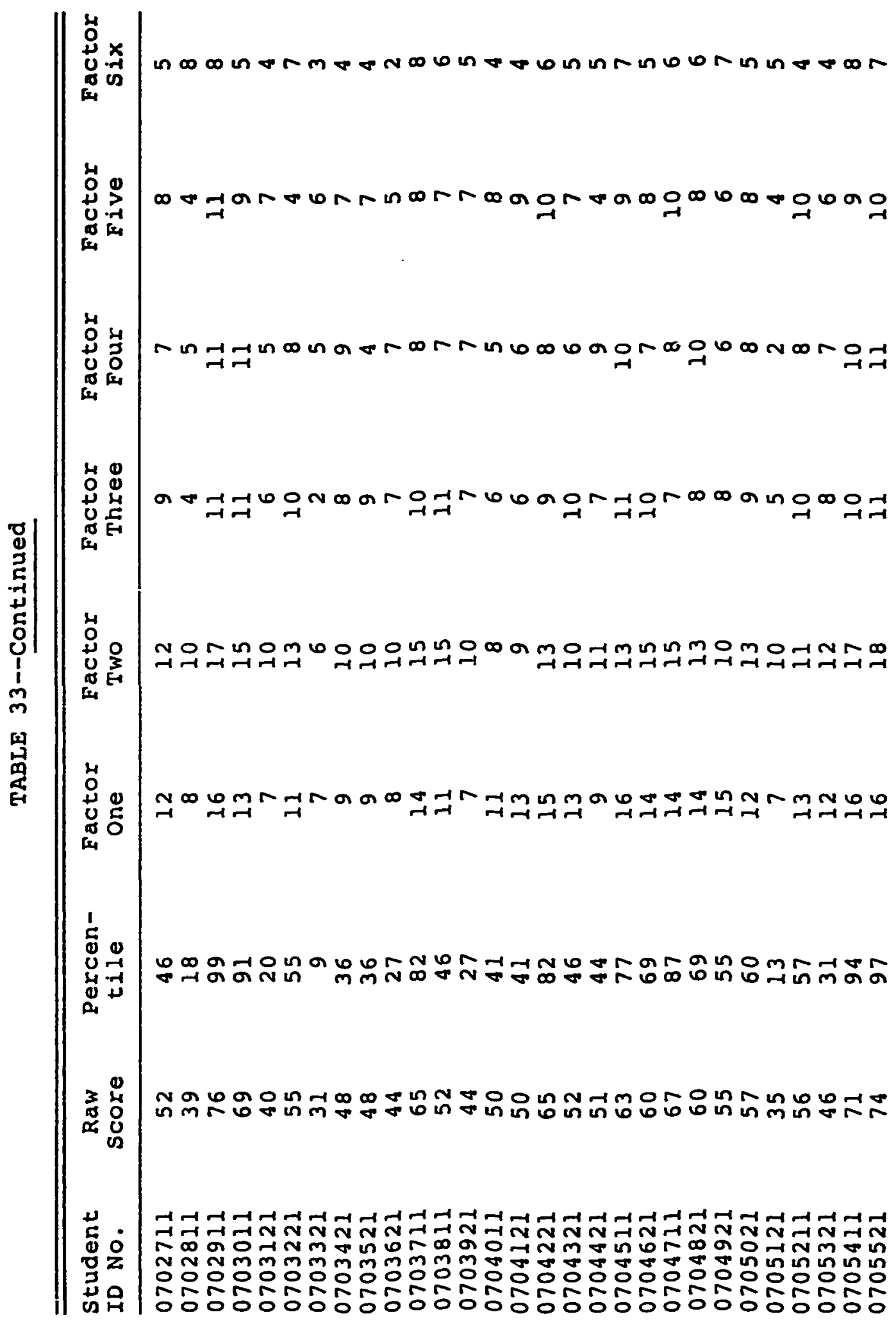




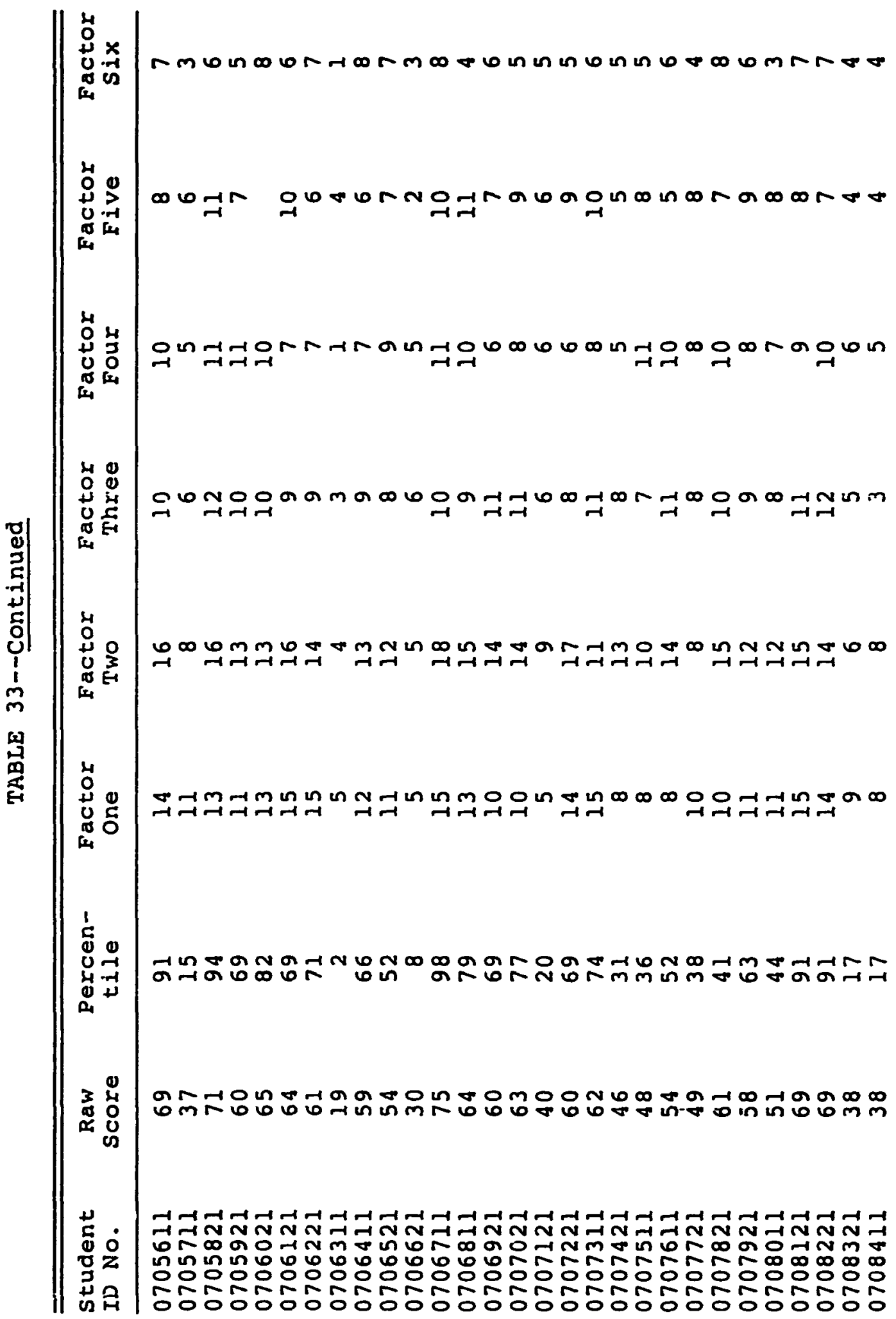




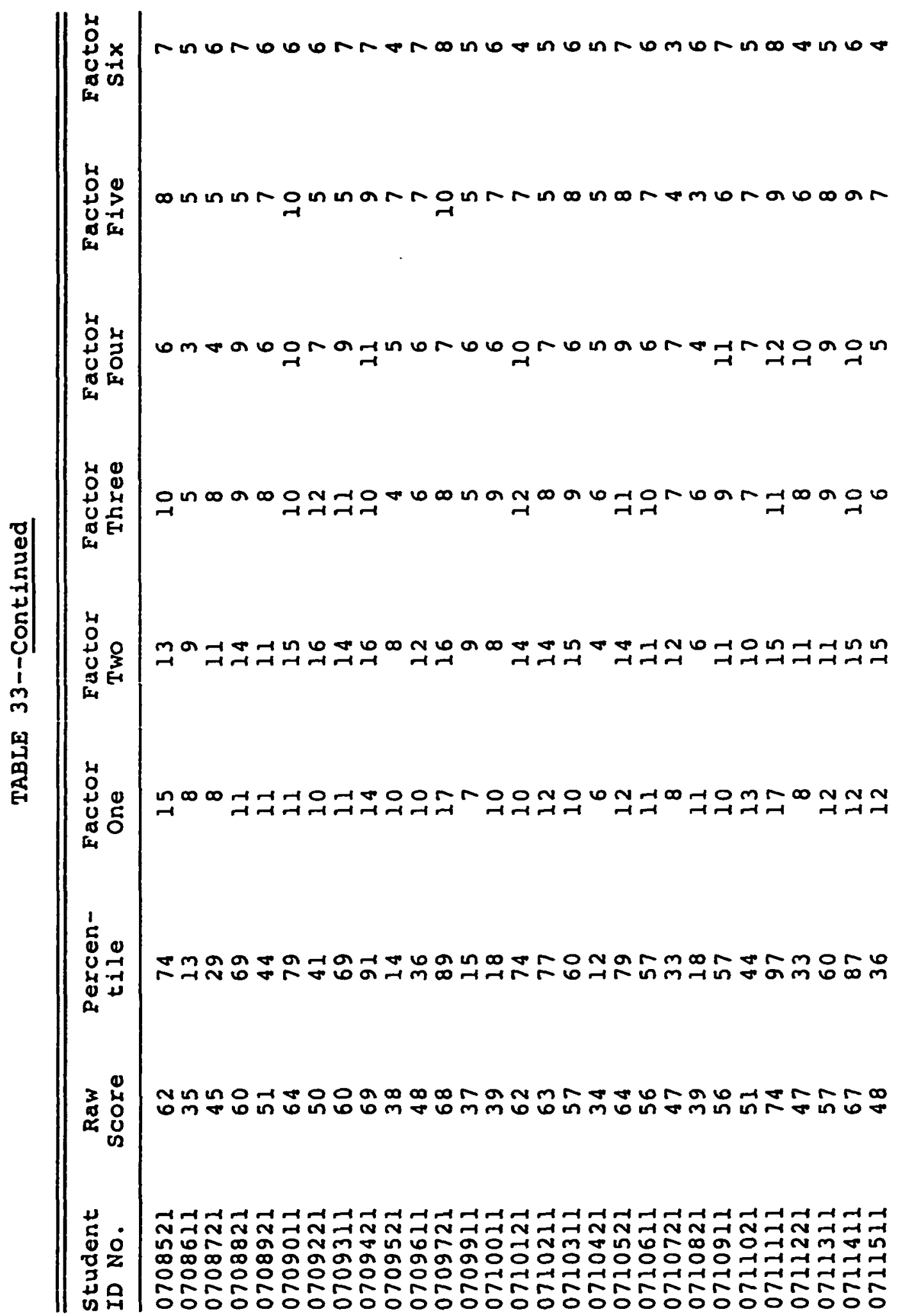


TABLE 33--Continued

\begin{tabular}{|c|c|c|c|c|c|c|c|c|}
\hline $\begin{array}{l}\text { student } \\
\text { ID No. }\end{array}$ & $\begin{array}{c}\text { Raw } \\
\text { Score }\end{array}$ & $\begin{array}{c}\text { Percen- } \\
\text { tile }\end{array}$ & $\begin{array}{c}\text { Factor } \\
\text { One }\end{array}$ & $\begin{array}{c}\text { Factor } \\
\text { Two }\end{array}$ & $\begin{array}{c}\text { Factor } \\
\text { Three }\end{array}$ & $\begin{array}{l}\text { Factor } \\
\text { Four }\end{array}$ & $\begin{array}{c}\text { Factor } \\
\text { Five }\end{array}$ & $\begin{array}{c}\text { Factor } \\
\text { Six }\end{array}$ \\
\hline $\begin{array}{l}0711611 \\
0711711 \\
0711821 \\
0711911 \\
0712011 \\
0712111 \\
0712221 \\
0712321 \\
0712411 \\
0712521 \\
071262 \\
0712711 \\
0712811 \\
0712911 \\
0713011 \\
0713111 \\
0713211 \\
0713321 \\
0713421 \\
0713511 \\
0713621 \\
0713711 \\
0713811 \\
0713911 \\
0714011 \\
0714111 \\
0714211 \\
0714311\end{array}$ & $\begin{array}{l}57 \\
52 \\
72 \\
36 \\
55 \\
63 \\
54 \\
73 \\
60 \\
62 \\
50 \\
71 \\
68 \\
26 \\
29 \\
66 \\
66 \\
64 \\
49 \\
51 \\
32 \\
71 \\
40 \\
64 \\
55 \\
67 \\
52 \\
60\end{array}$ & $\begin{array}{l}60 \\
46 \\
95 \\
14 \\
55 \\
77 \\
52 \\
96 \\
69 \\
74 \\
41 \\
94 \\
89 \\
5 \\
7 \\
85 \\
85 \\
79 \\
38 \\
44 \\
10 \\
94 \\
20 \\
79 \\
55 \\
87 \\
46 \\
69\end{array}$ & $\begin{array}{r}12 \\
12 \\
16 \\
8 \\
11 \\
12 \\
9 \\
17 \\
13 \\
11 \\
10 \\
16 \\
14 \\
3 \\
6 \\
13 \\
15 \\
13 \\
10 \\
9 \\
5 \\
18 \\
7 \\
14 \\
12 \\
15 \\
9 \\
16\end{array}$ & $\begin{array}{r}12 \\
15 \\
16 \\
9 \\
13 \\
14 \\
13 \\
16 \\
13 \\
12 \\
10 \\
17 \\
16 \\
9 \\
7 \\
15 \\
17 \\
12 \\
10 \\
12 \\
7 \\
15 \\
10 \\
14 \\
14 \\
12 \\
12 \\
14\end{array}$ & $\begin{array}{r}11 \\
8 \\
9 \\
7 \\
8 \\
10 \\
7 \\
10 \\
9 \\
10 \\
6 \\
9 \\
11 \\
3 \\
3 \\
11 \\
11 \\
10 \\
8 \\
6 \\
4 \\
10 \\
6 \\
10 \\
6 \\
11 \\
8 \\
8\end{array}$ & $\begin{array}{r}6 \\
6 \\
9 \\
4 \\
6 \\
7 \\
8 \\
9 \\
9 \\
10 \\
9 \\
9 \\
9 \\
4 \\
8 \\
10 \\
7 \\
9 \\
6 \\
7 \\
4 \\
10 \\
4 \\
120 \\
7 \\
10 \\
7 \\
9\end{array}$ & $\begin{array}{r}7 \\
6 \\
10 \\
7 \\
8 \\
10 \\
6 \\
9 \\
4 \\
7 \\
2 \\
7 \\
8 \\
3 \\
5 \\
9 \\
9 \\
9 \\
5 \\
6 \\
4 \\
8 \\
8 \\
9 \\
6 \\
9 \\
7 \\
20\end{array}$ & $\begin{array}{l}5 \\
6 \\
6 \\
2 \\
6 \\
7 \\
6 \\
8 \\
7 \\
8 \\
8 \\
7 \\
7 \\
2 \\
2 \\
7 \\
6 \\
5 \\
6 \\
5 \\
4 \\
8 \\
2 \\
6 \\
6 \\
8 \\
5 \\
7\end{array}$ \\
\hline
\end{tabular}




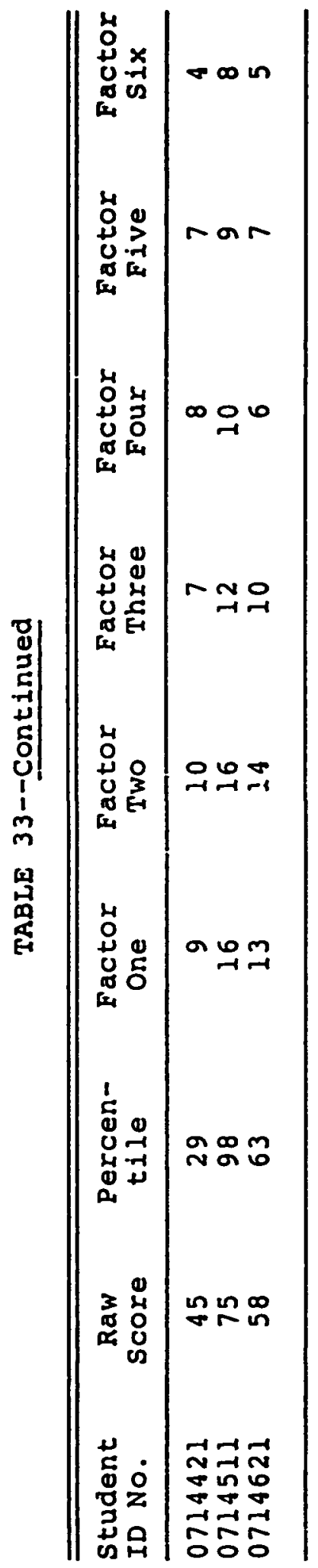




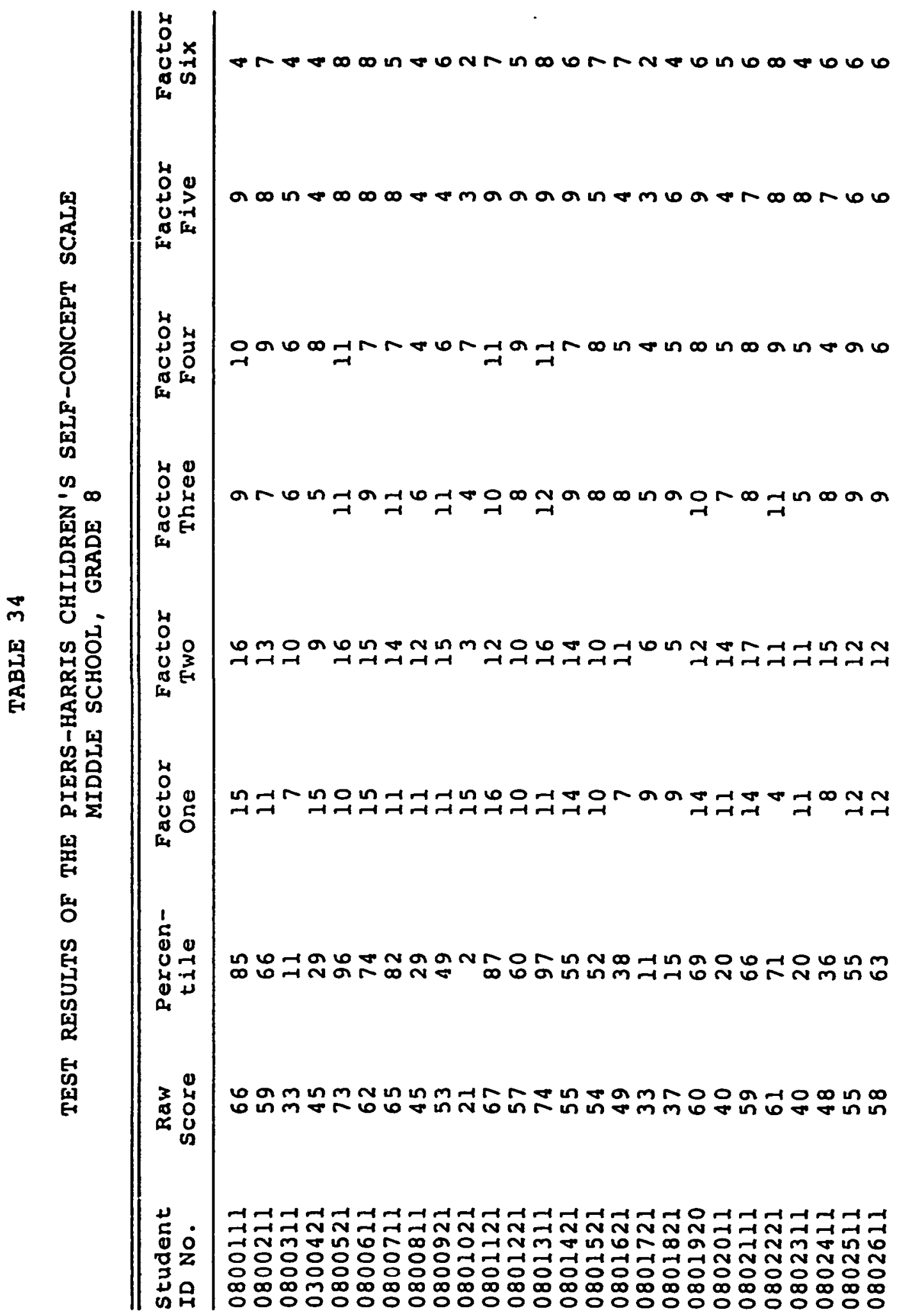




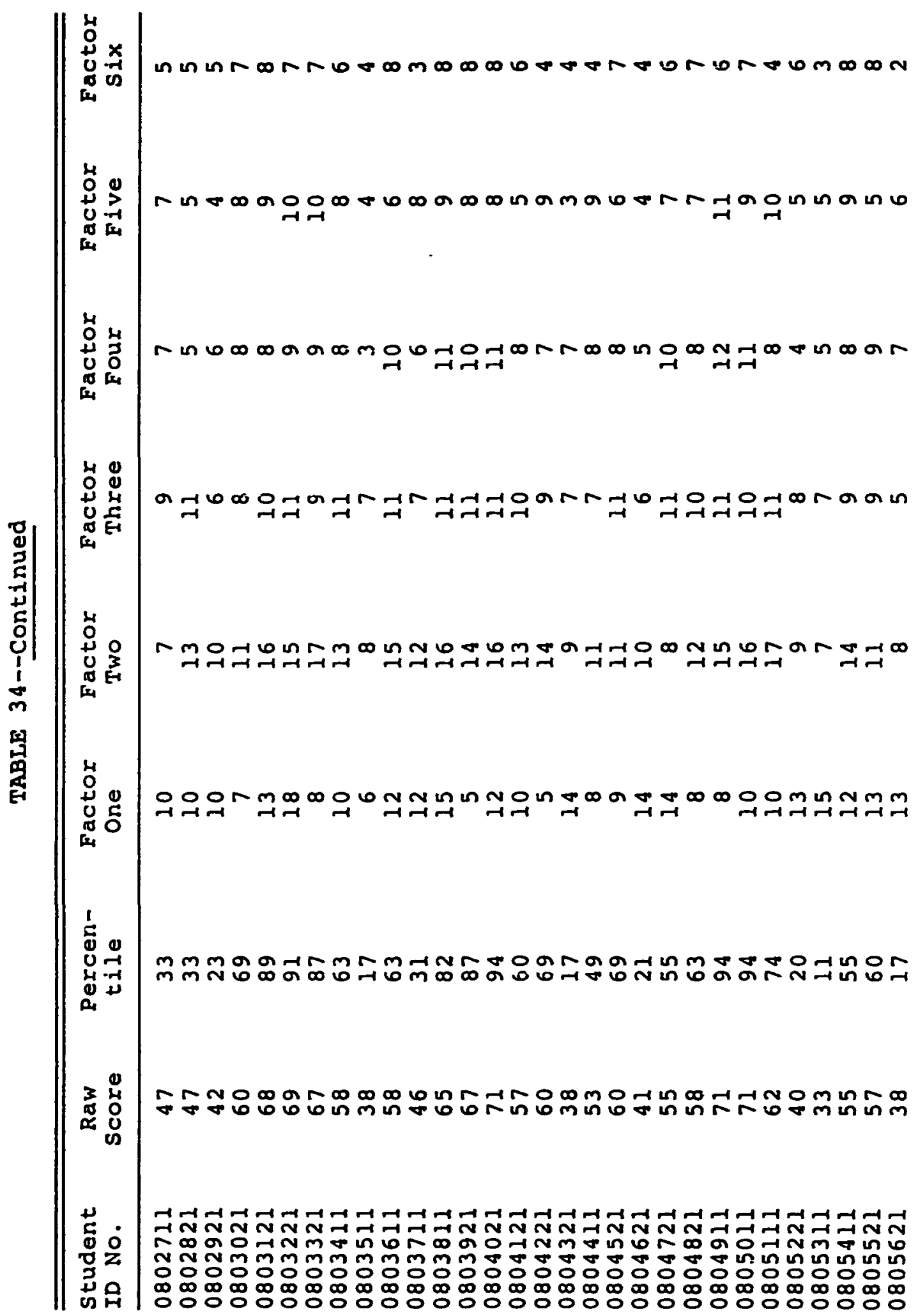




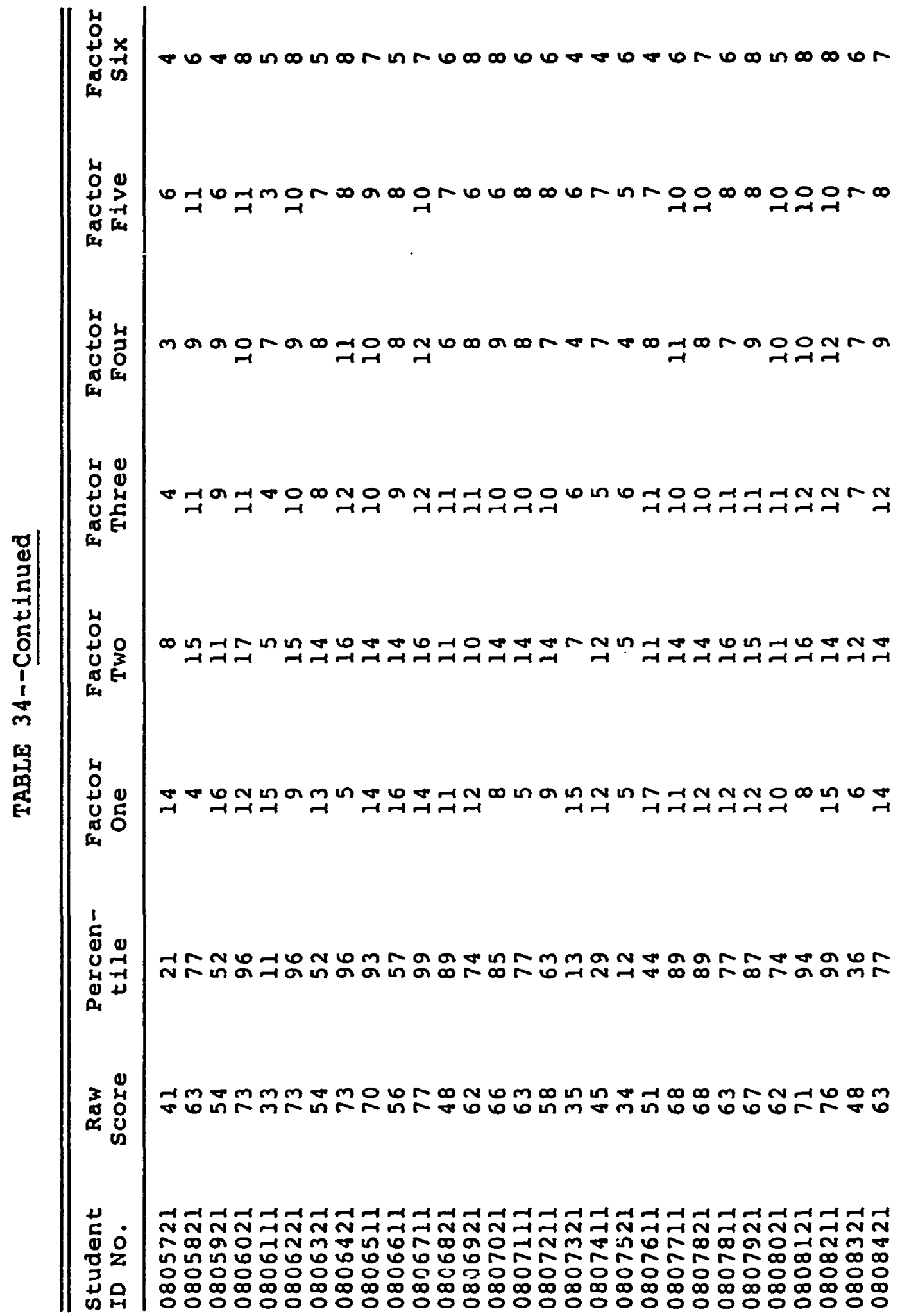




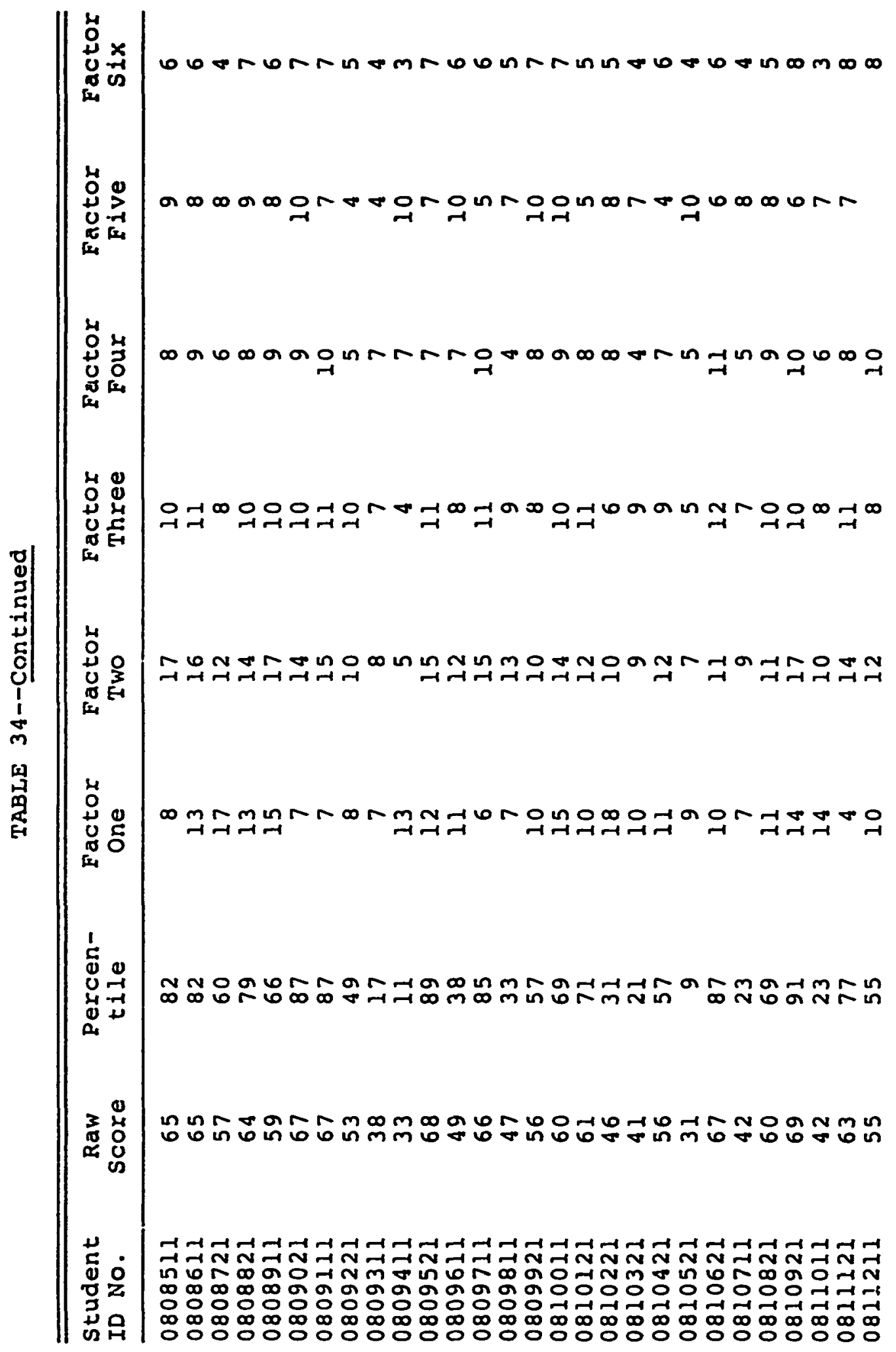




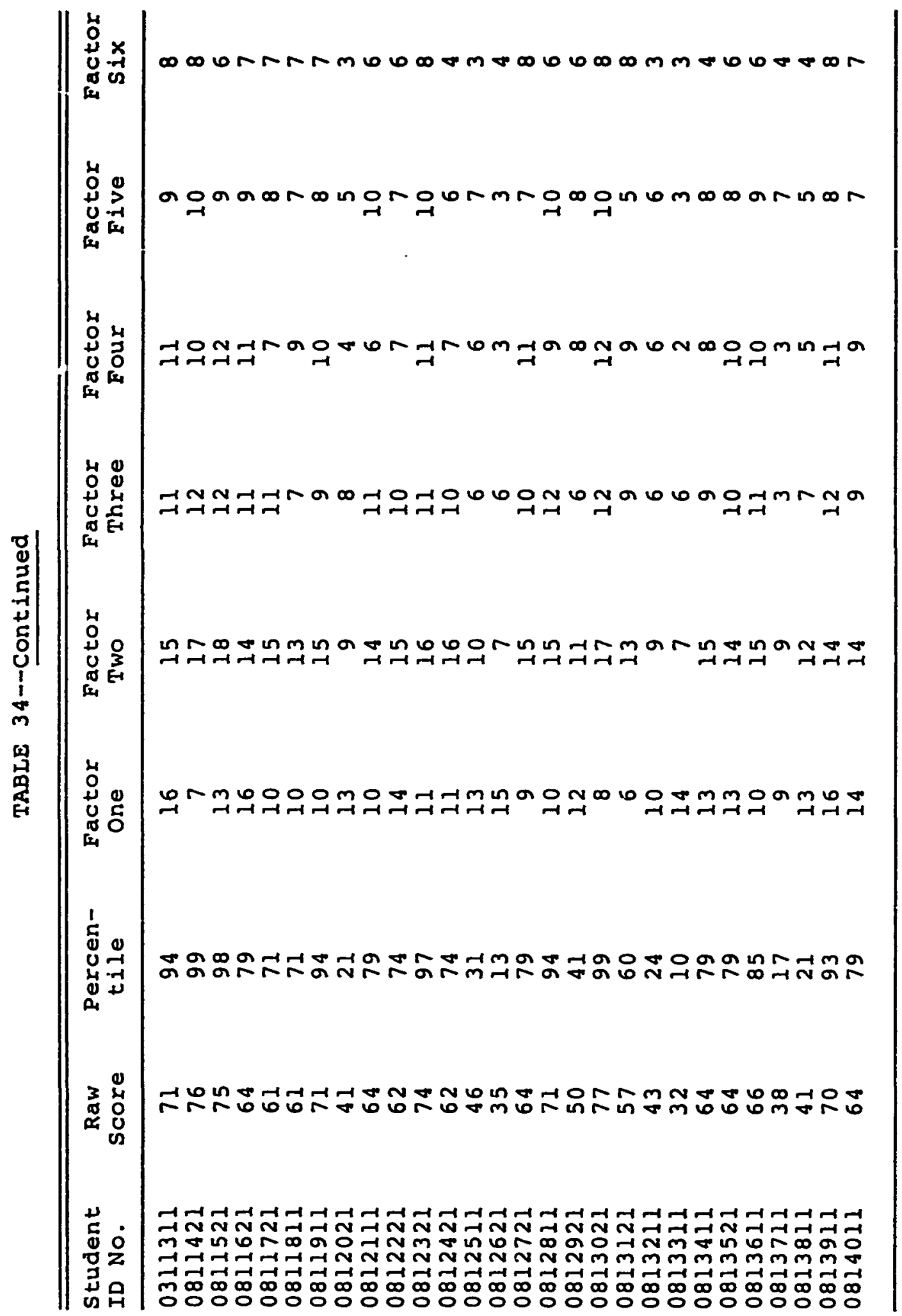




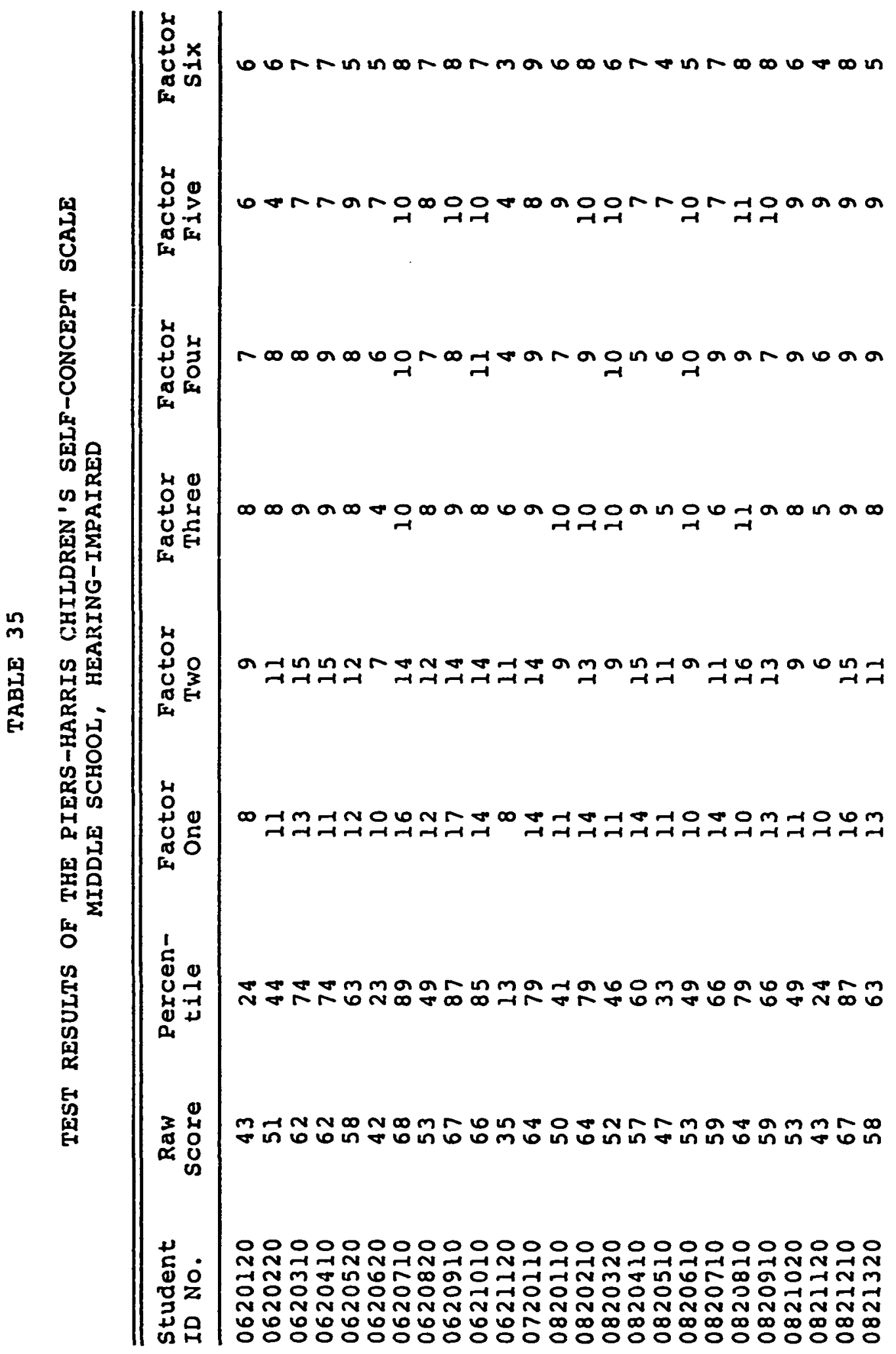


TABLE 35--Continued

\begin{tabular}{lcccccccc}
\hline $\begin{array}{l}\text { Student } \\
\text { ID No. }\end{array}$ & $\begin{array}{c}\text { Raw } \\
\text { Score }\end{array}$ & $\begin{array}{c}\text { Percen- } \\
\text { tile }\end{array}$ & $\begin{array}{c}\text { Factor } \\
\text { One }\end{array}$ & $\begin{array}{c}\text { Factor } \\
\text { Two }\end{array}$ & $\begin{array}{c}\text { Factor } \\
\text { Three }\end{array}$ & $\begin{array}{c}\text { Factor } \\
\text { Four }\end{array}$ & $\begin{array}{c}\text { Factor } \\
\text { Five }\end{array}$ & $\begin{array}{c}\text { Factor } \\
\text { Six }\end{array}$ \\
\hline 0821410 & 59 & 66 & 12 & 14 & 9 & 10 & 8 & 6 \\
0821520 & 61 & 71 & 11 & 13 & 11 & 9 & 10 & 9 \\
\hline
\end{tabular}




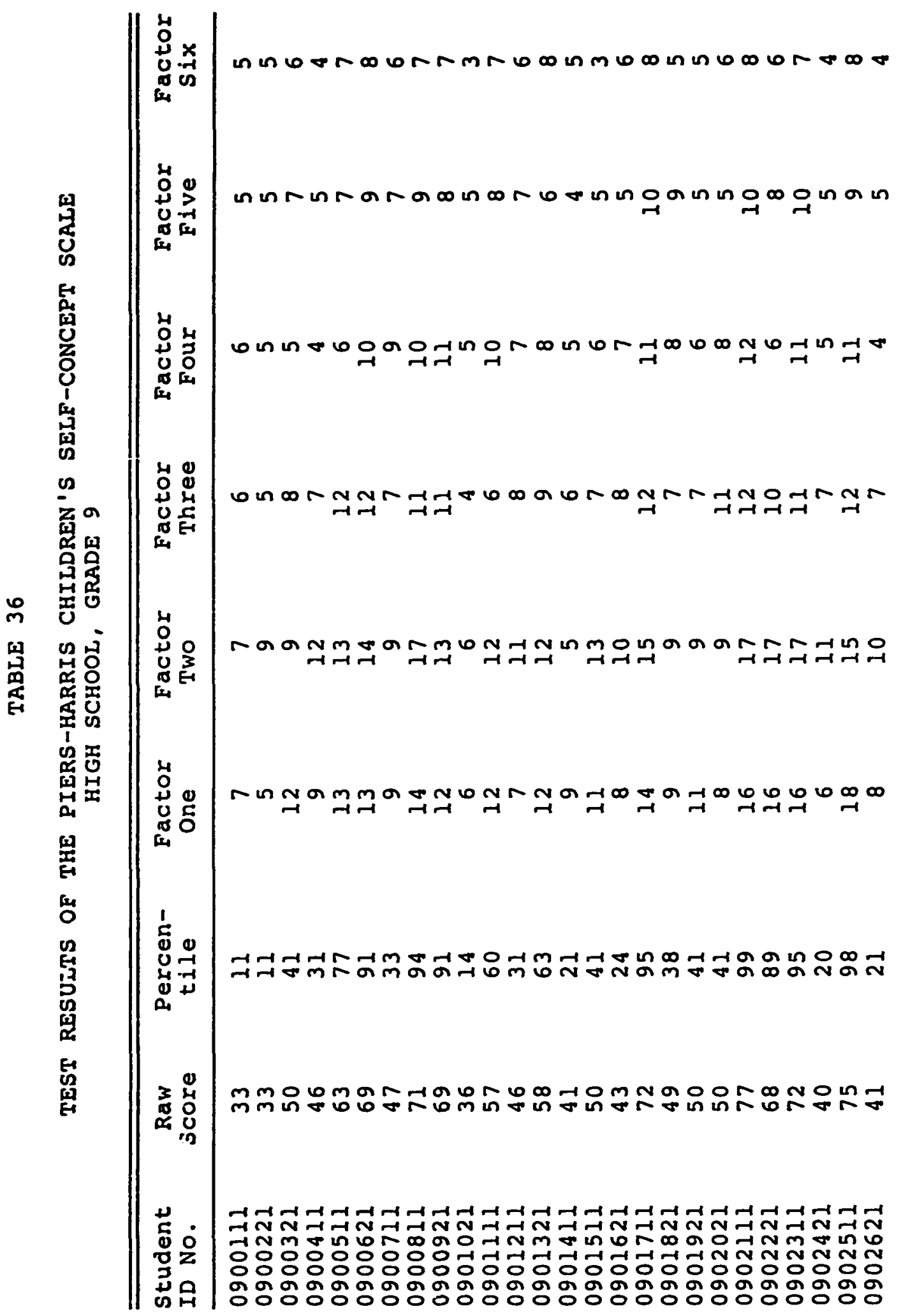




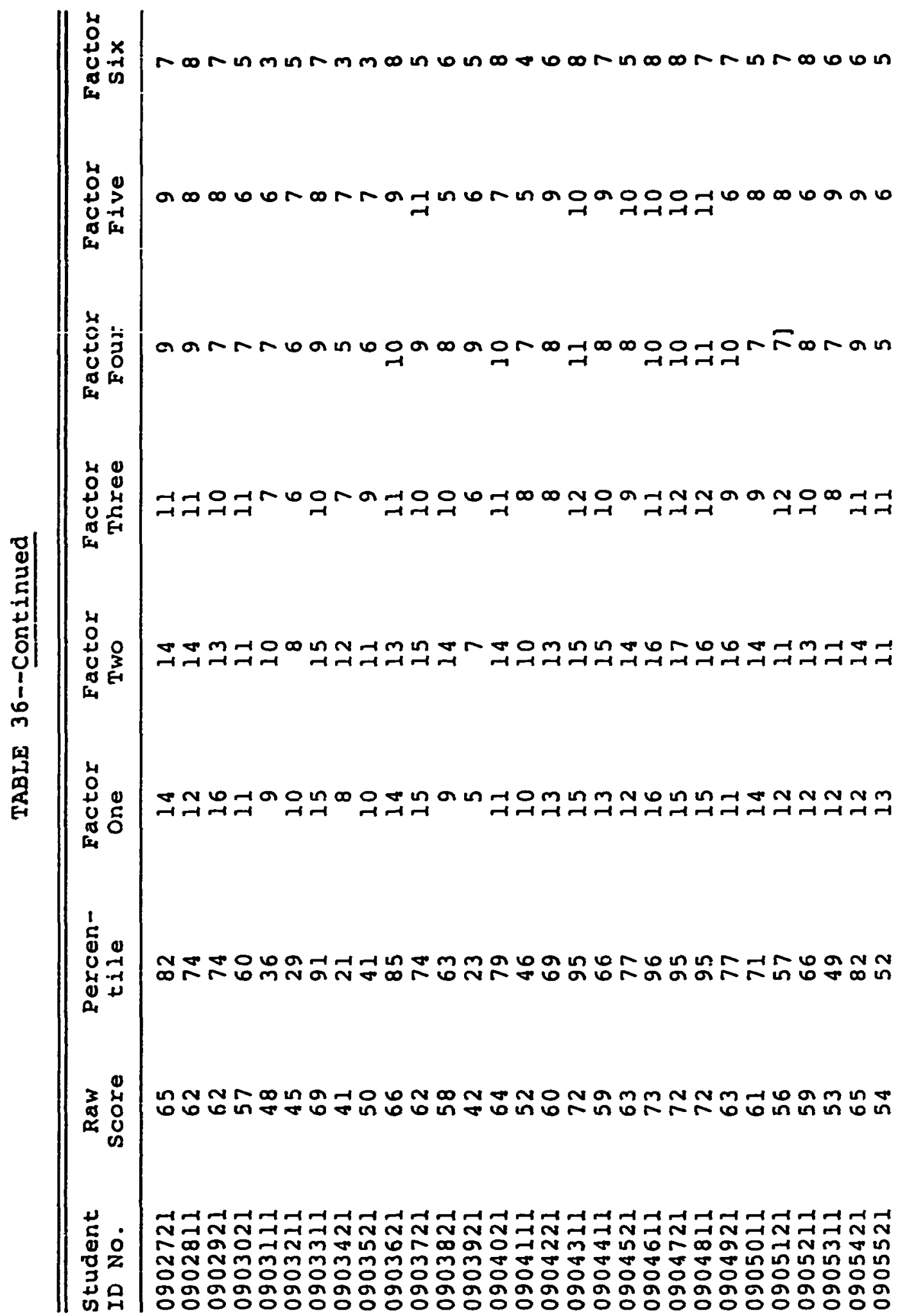




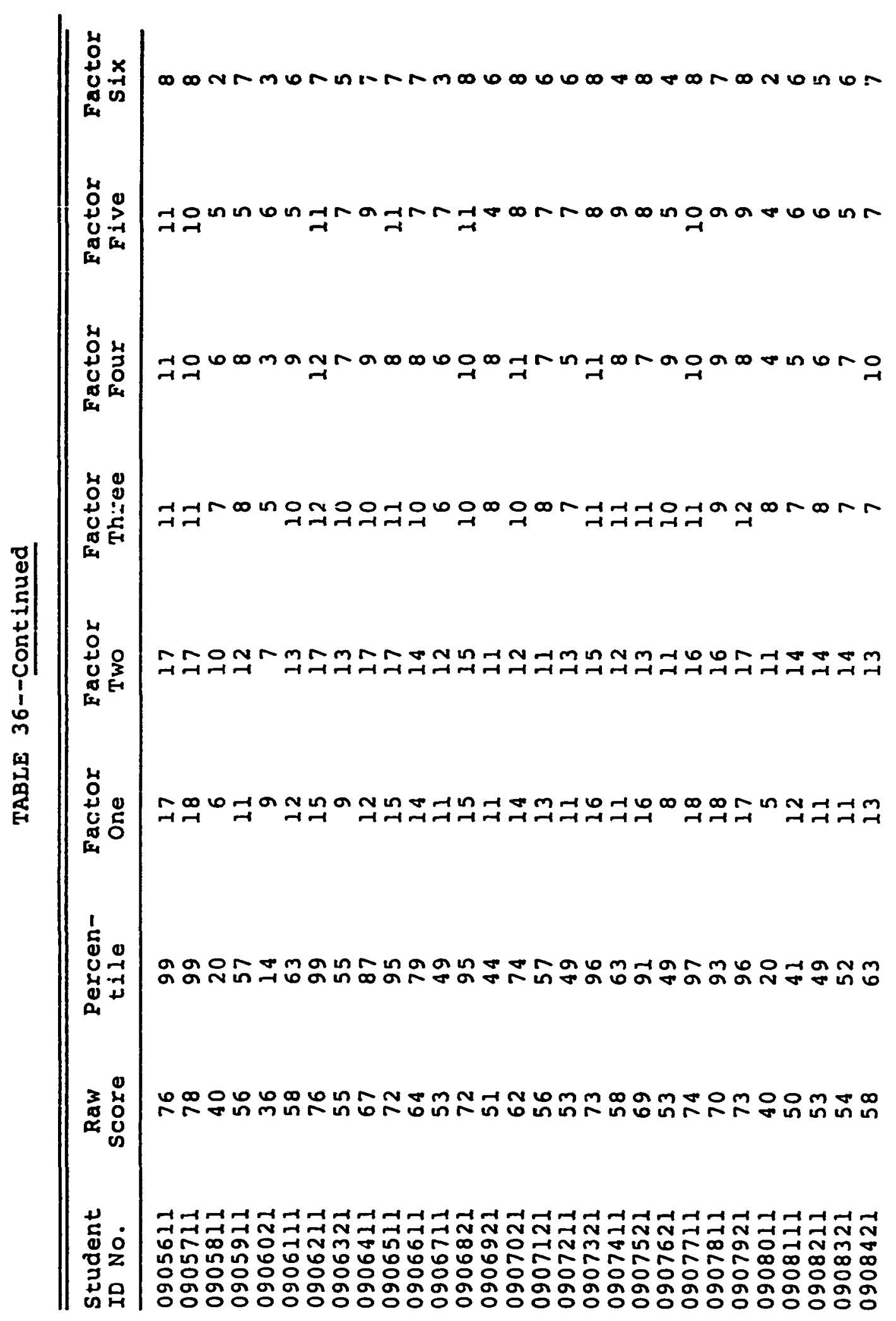




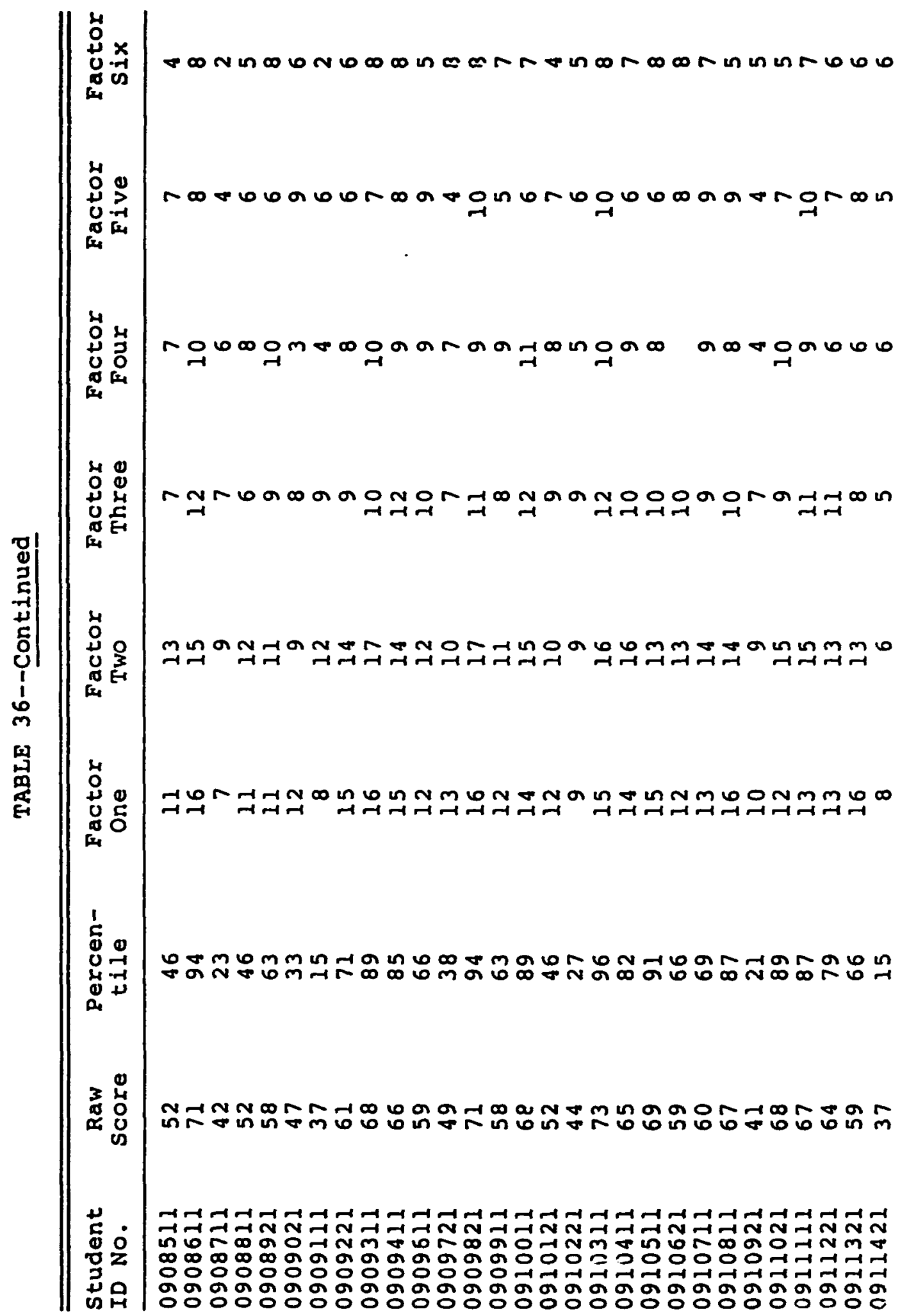




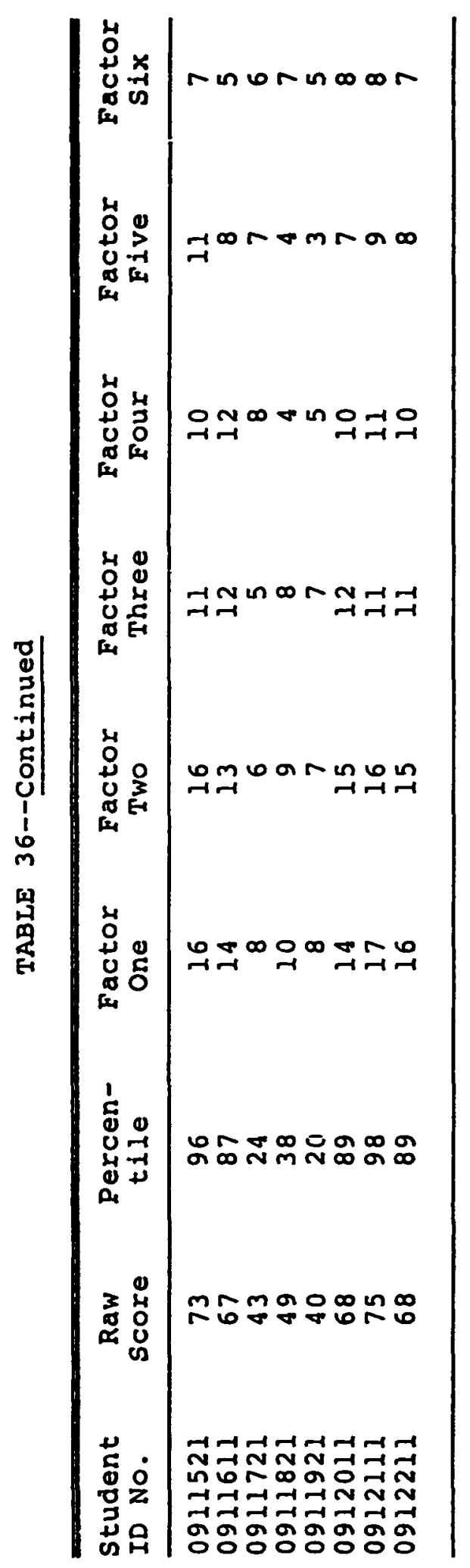

Reproduced with permission of the copyright owner. Further reproduction prohibited without permission. 


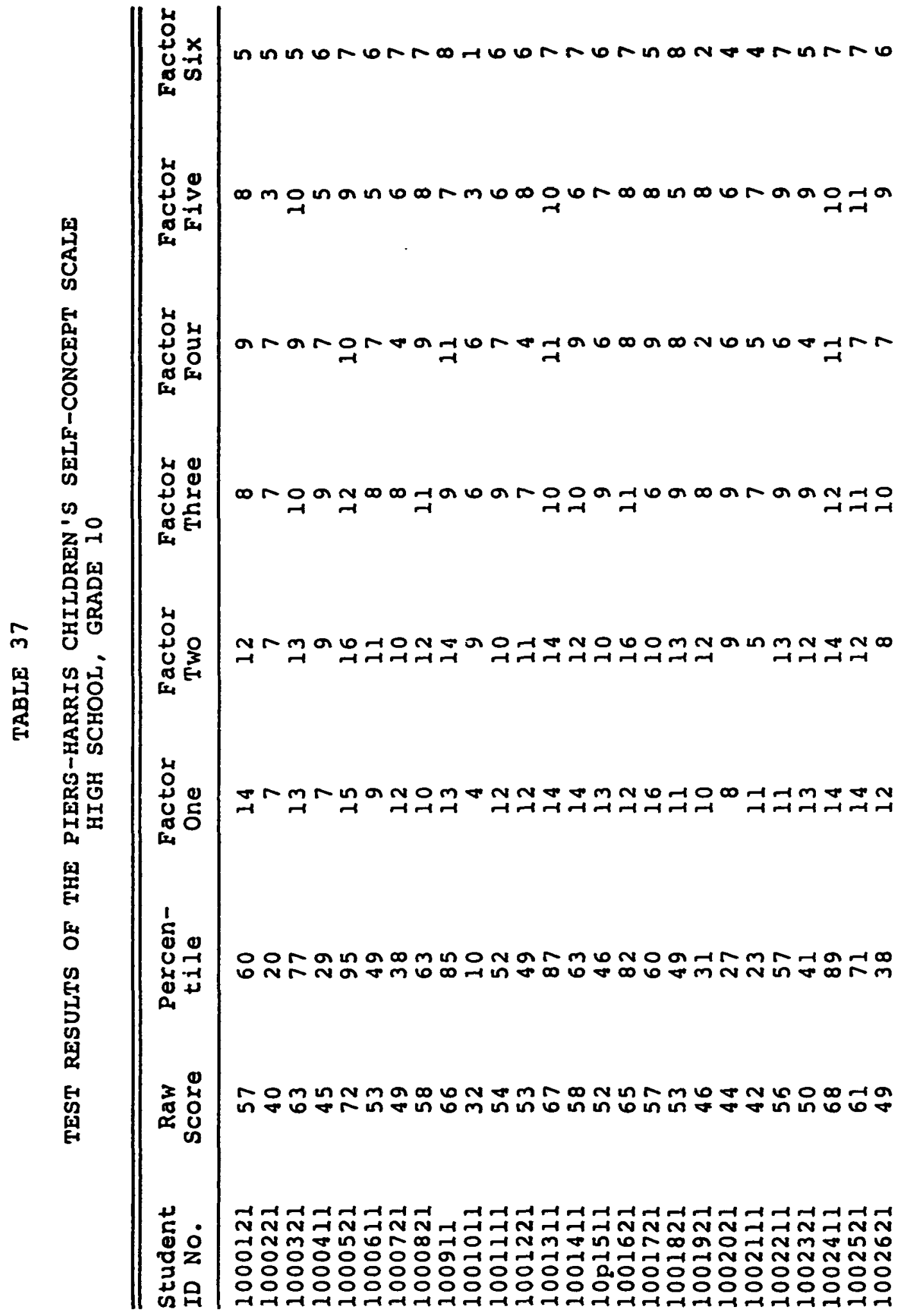




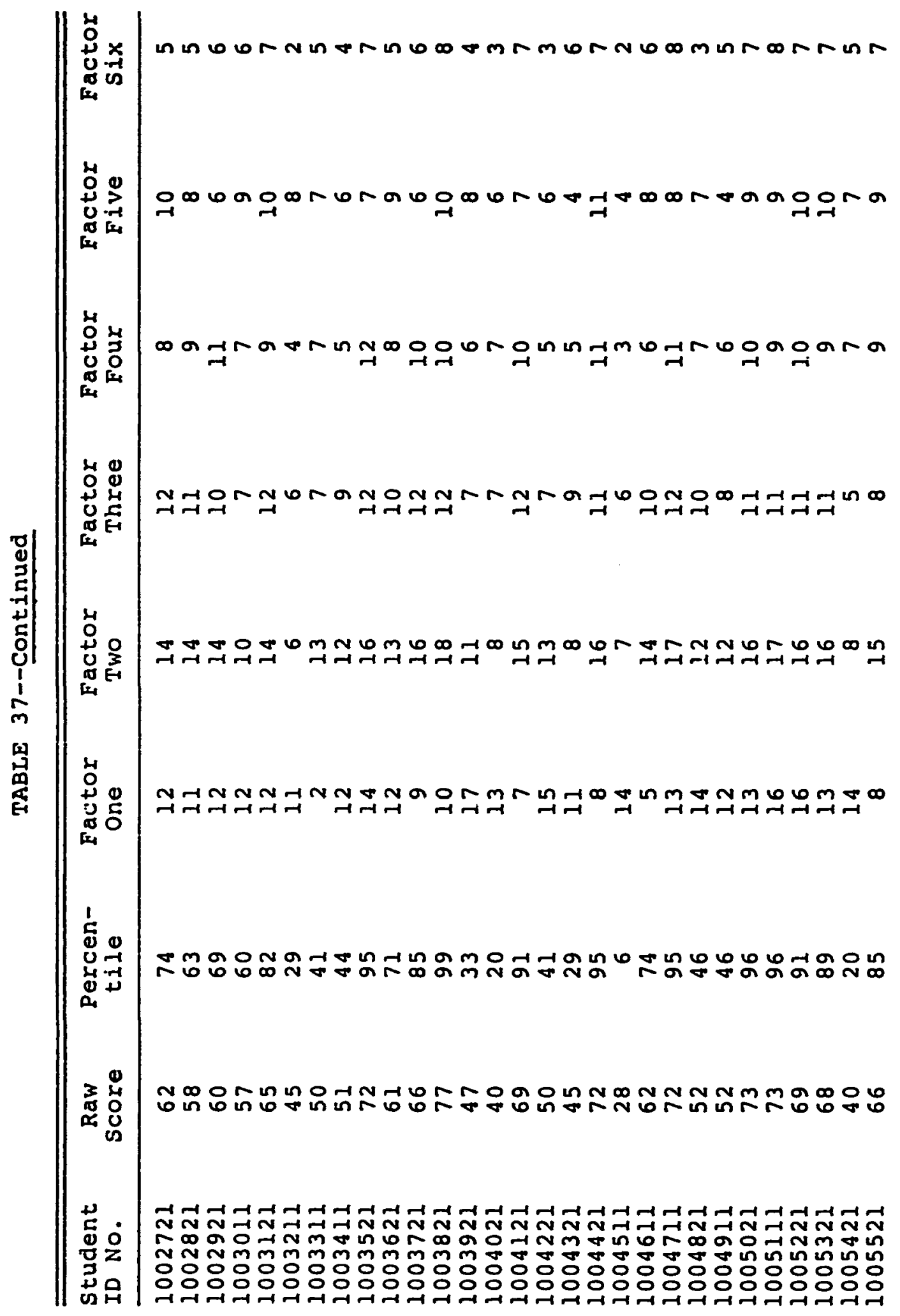




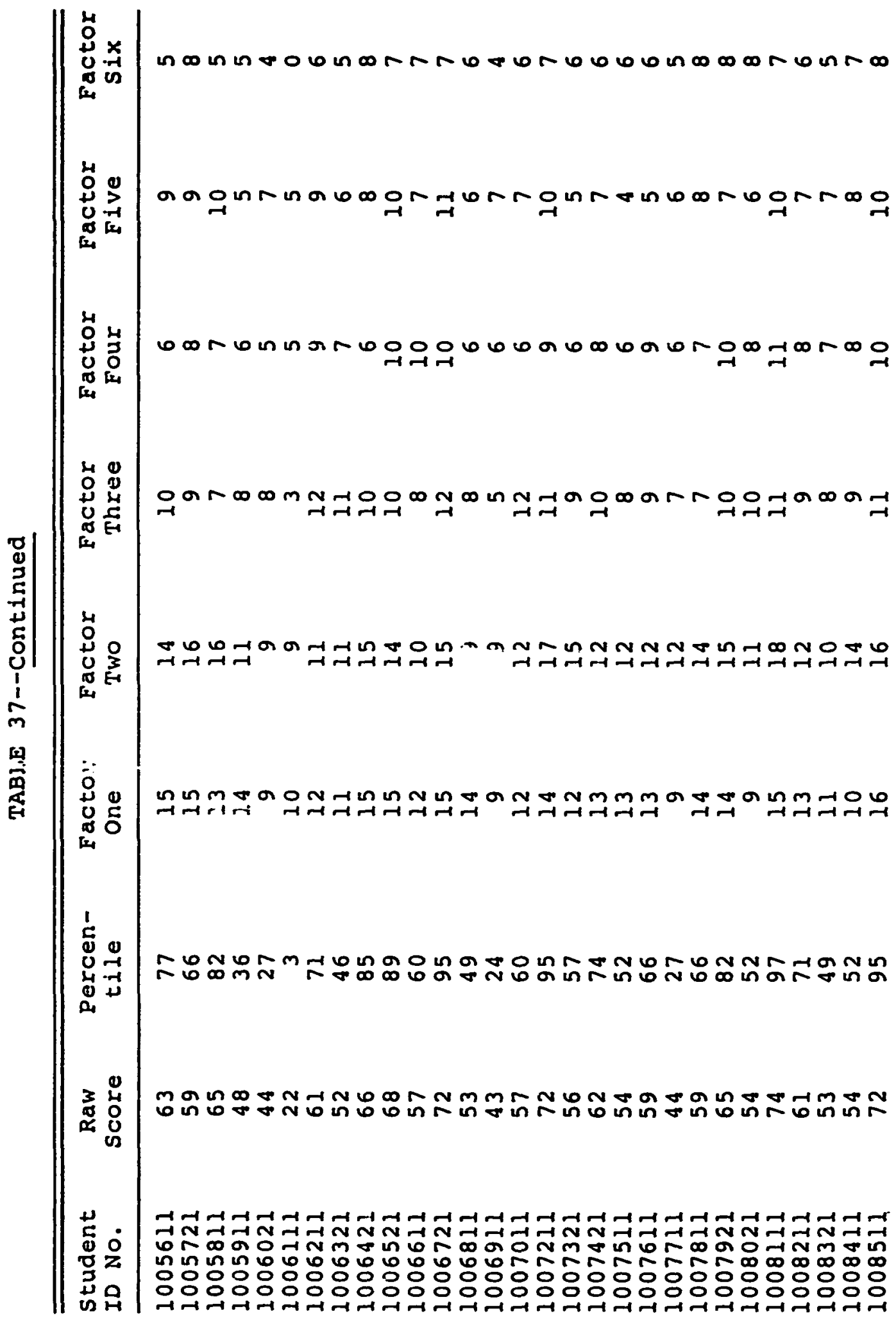




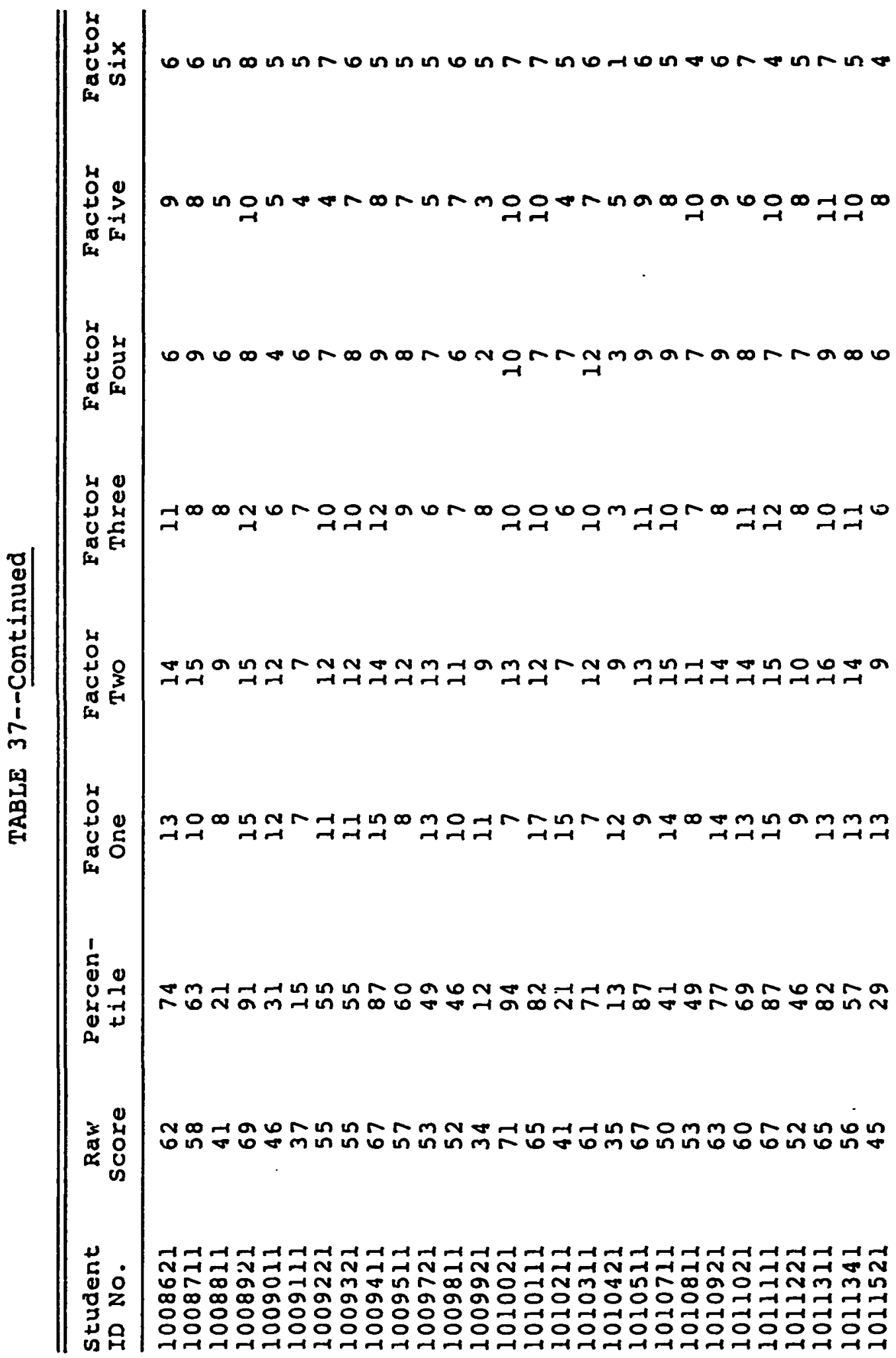




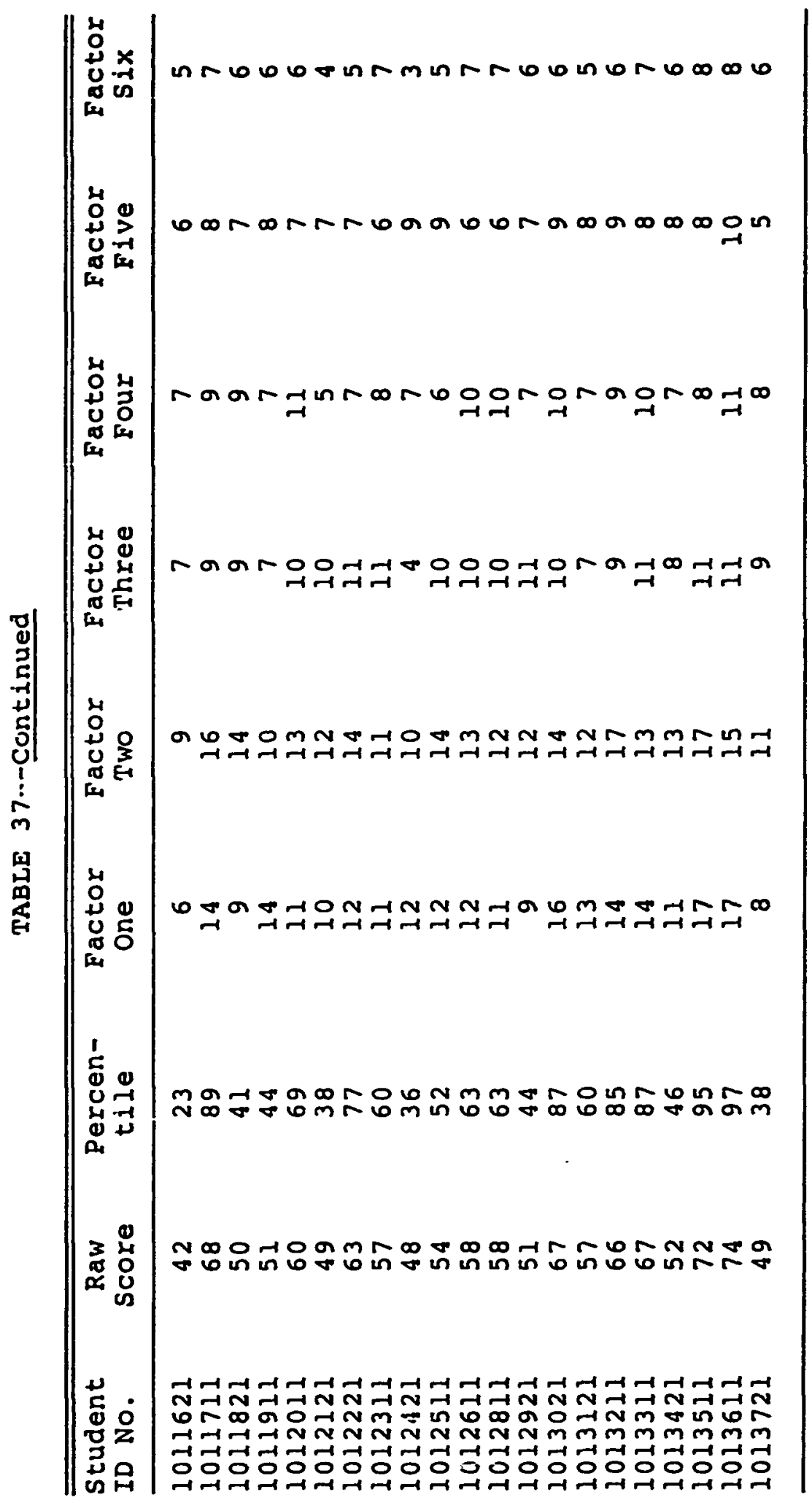




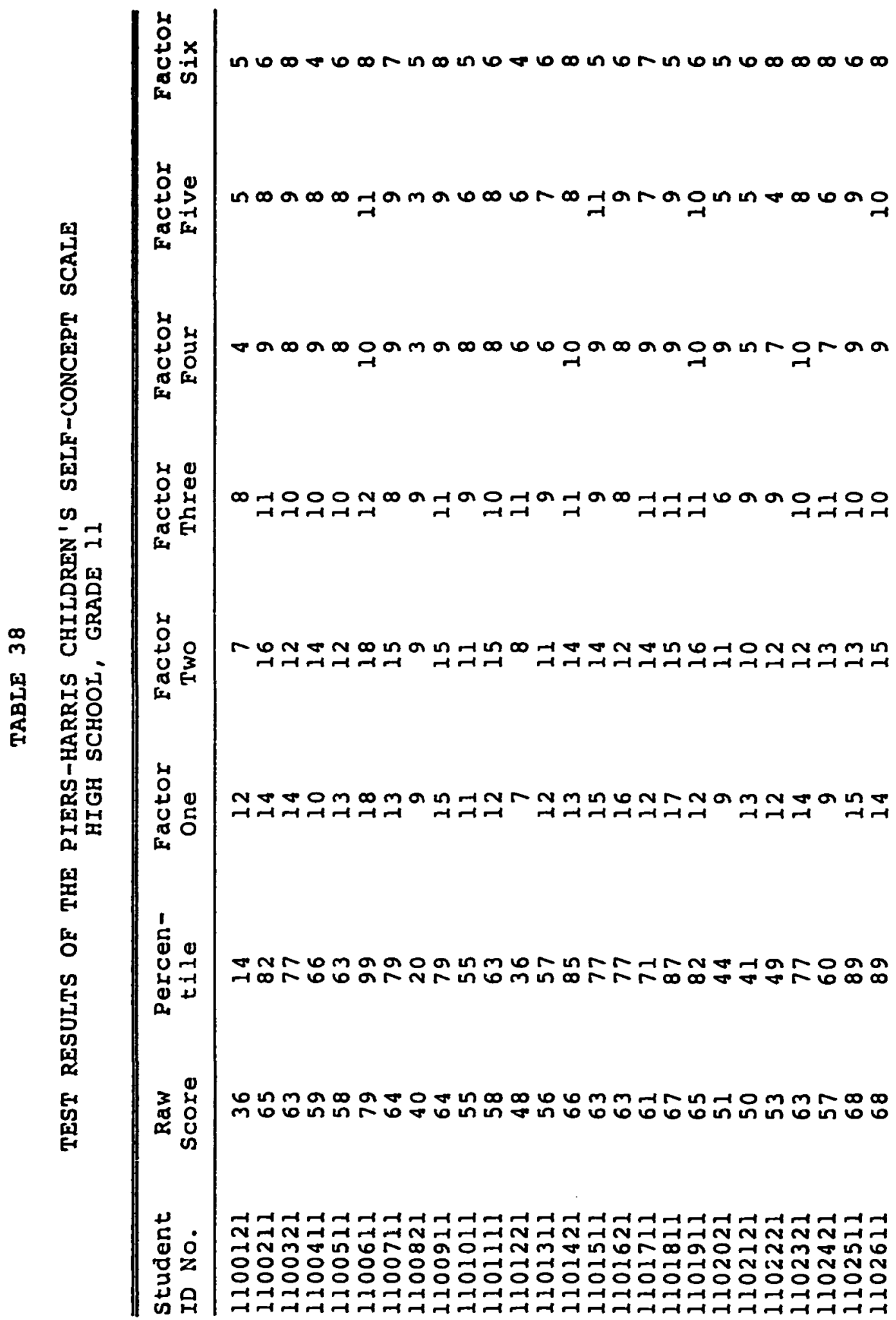




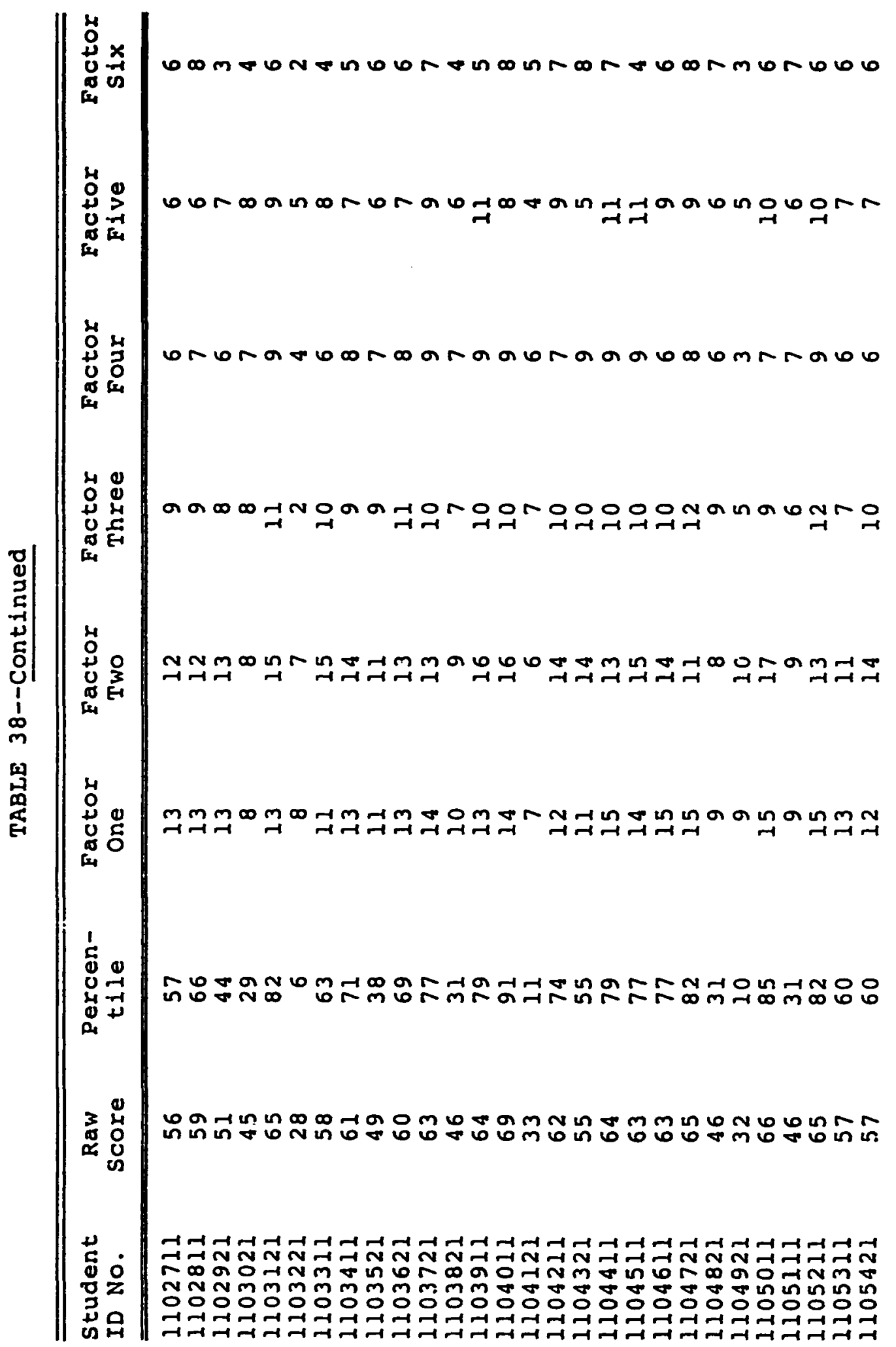




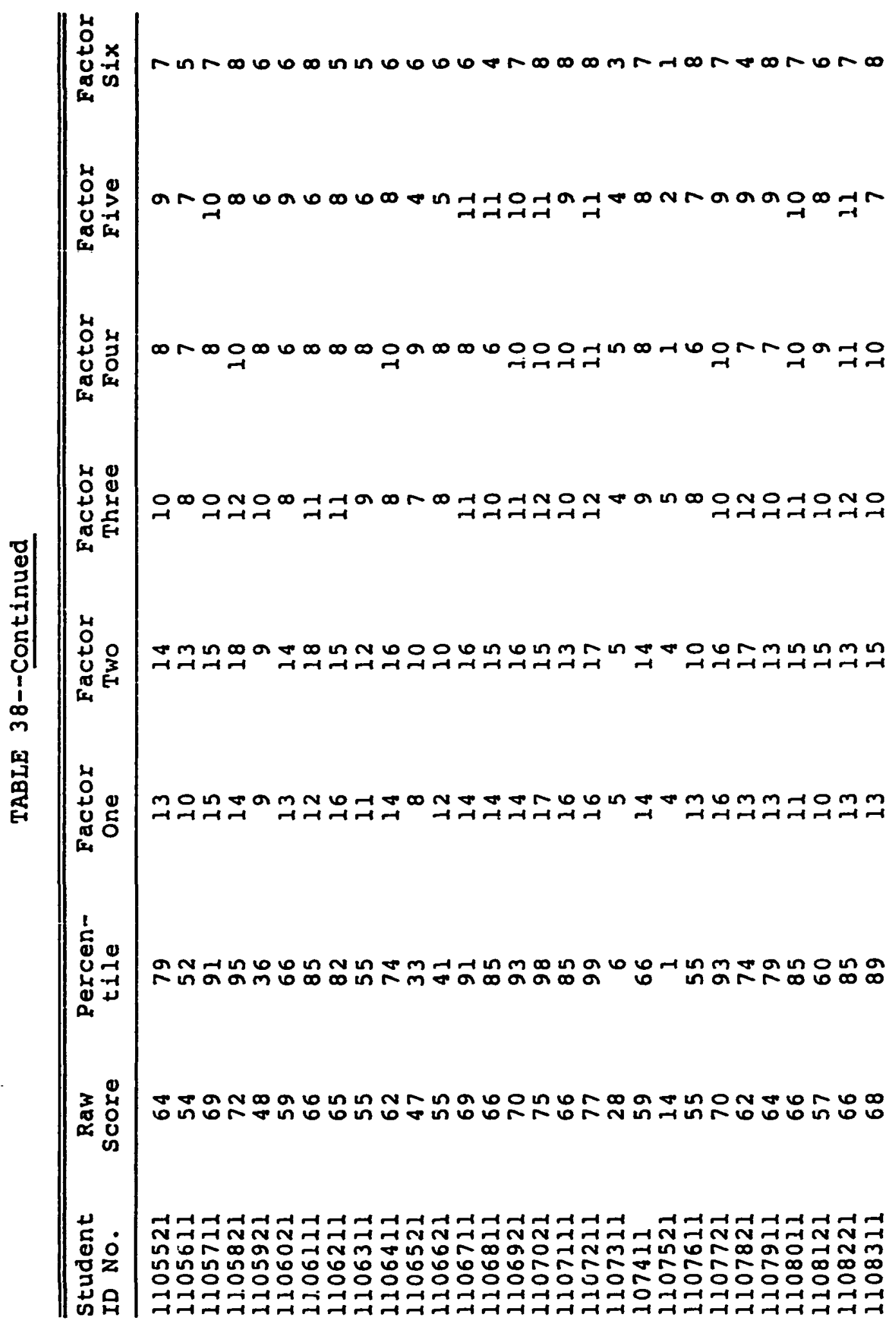




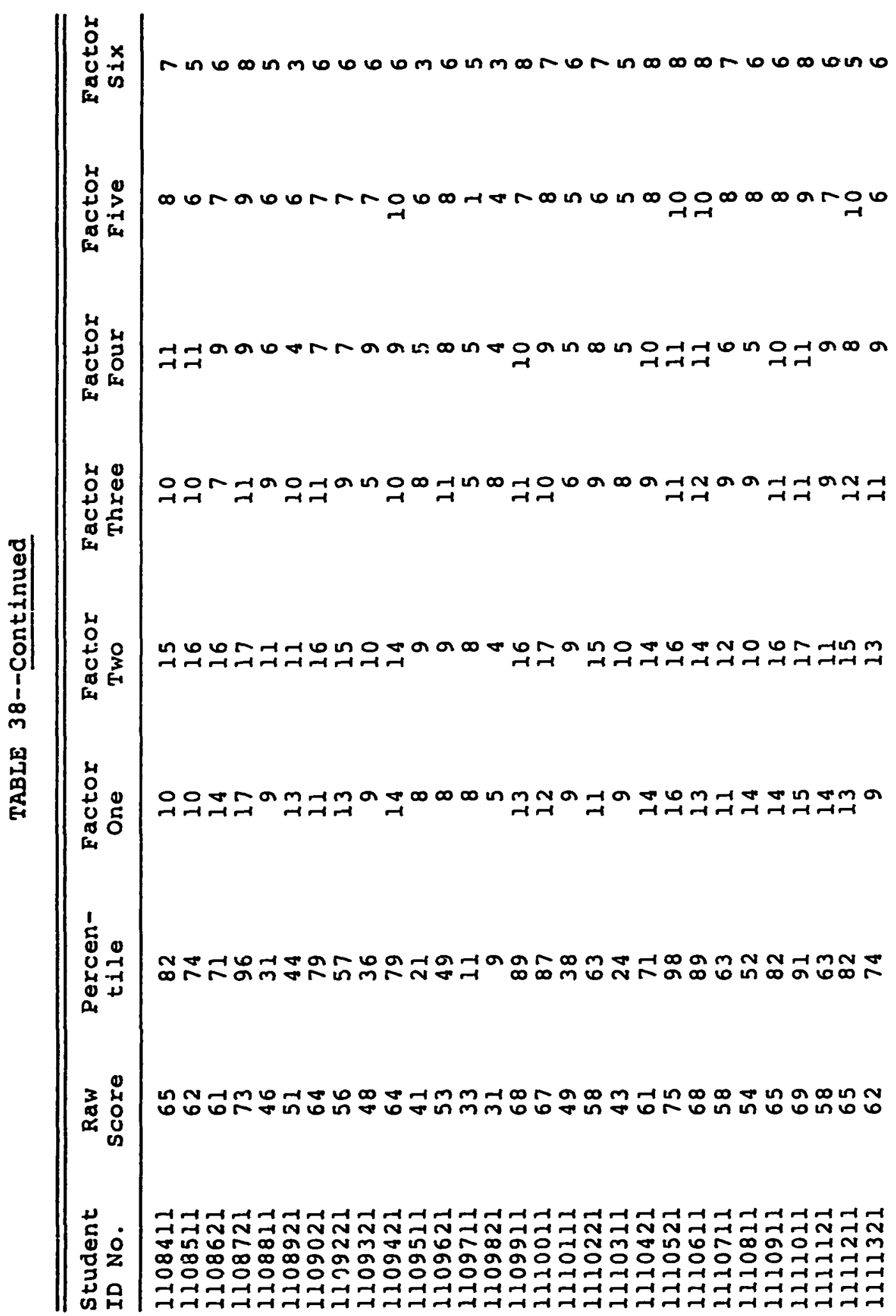




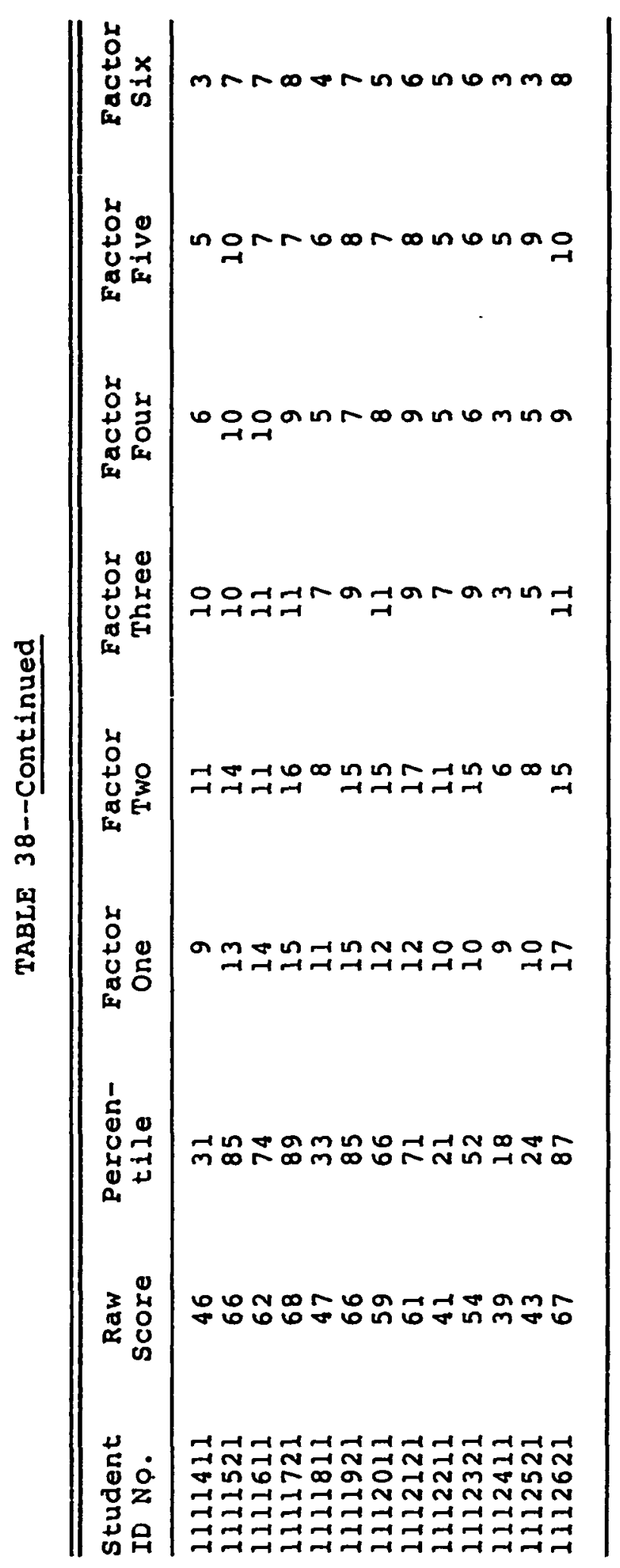

Reproduced with permission of the copyright owner. Further reproduction prohibited without permission. 


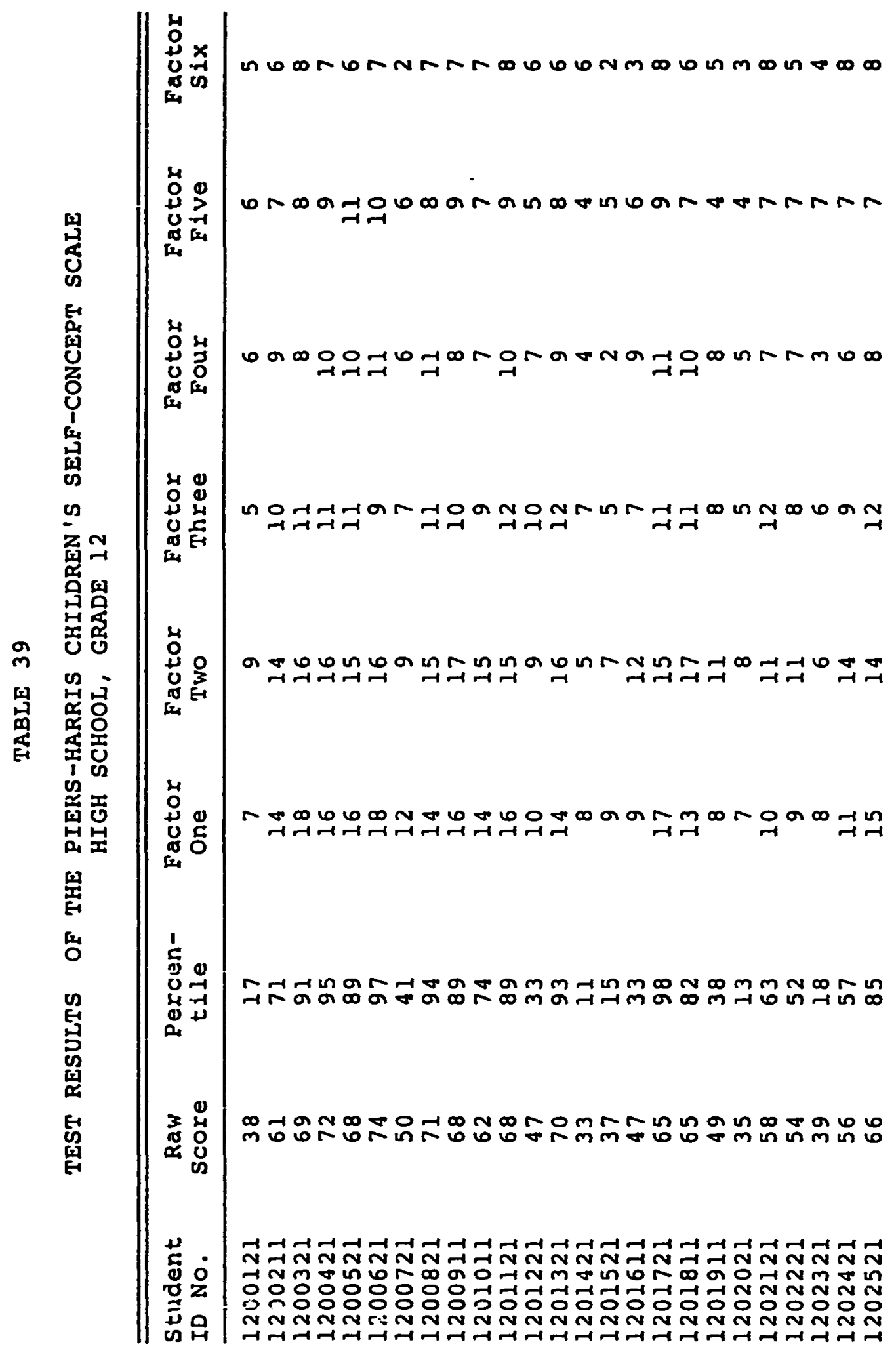




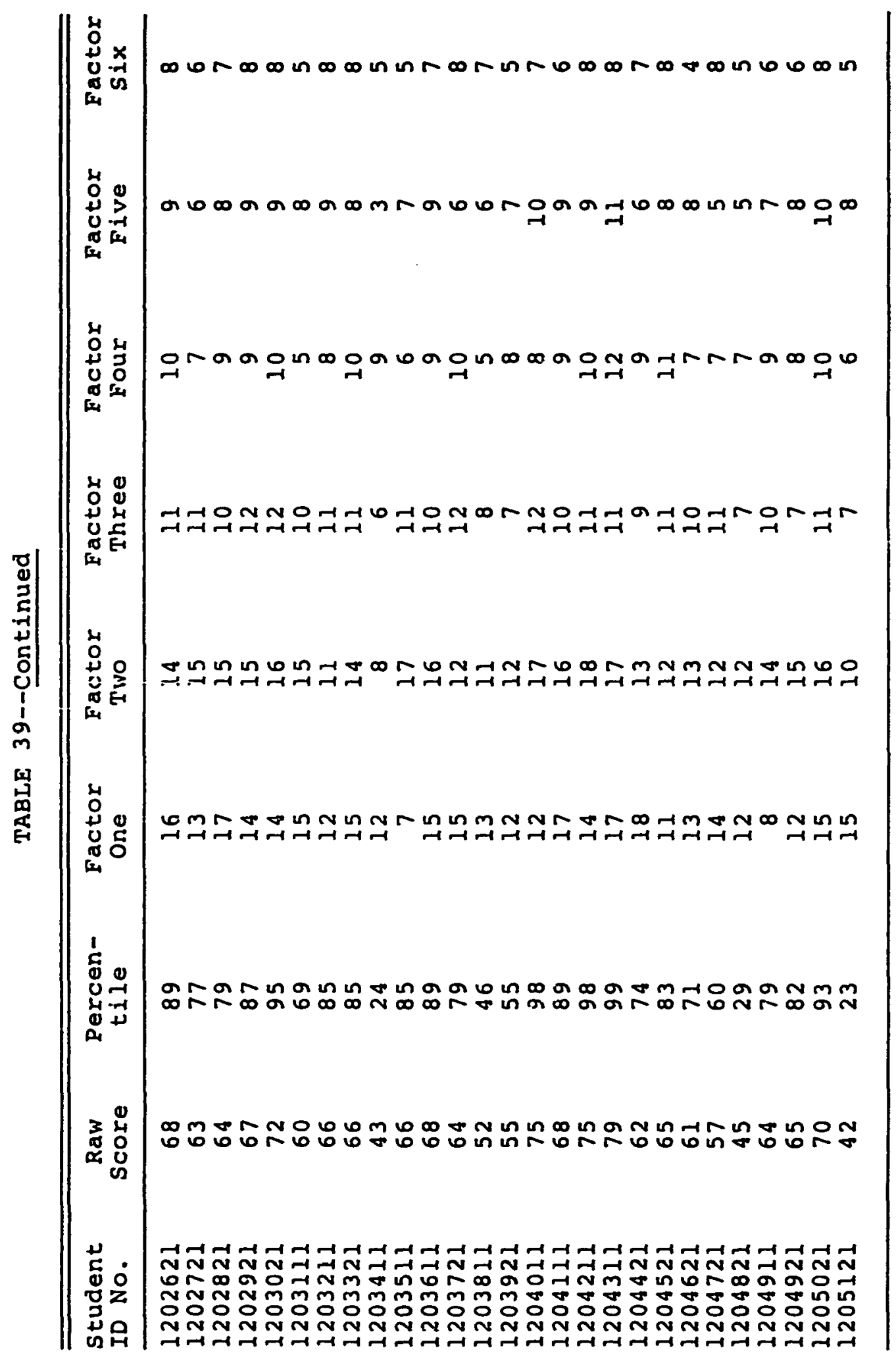




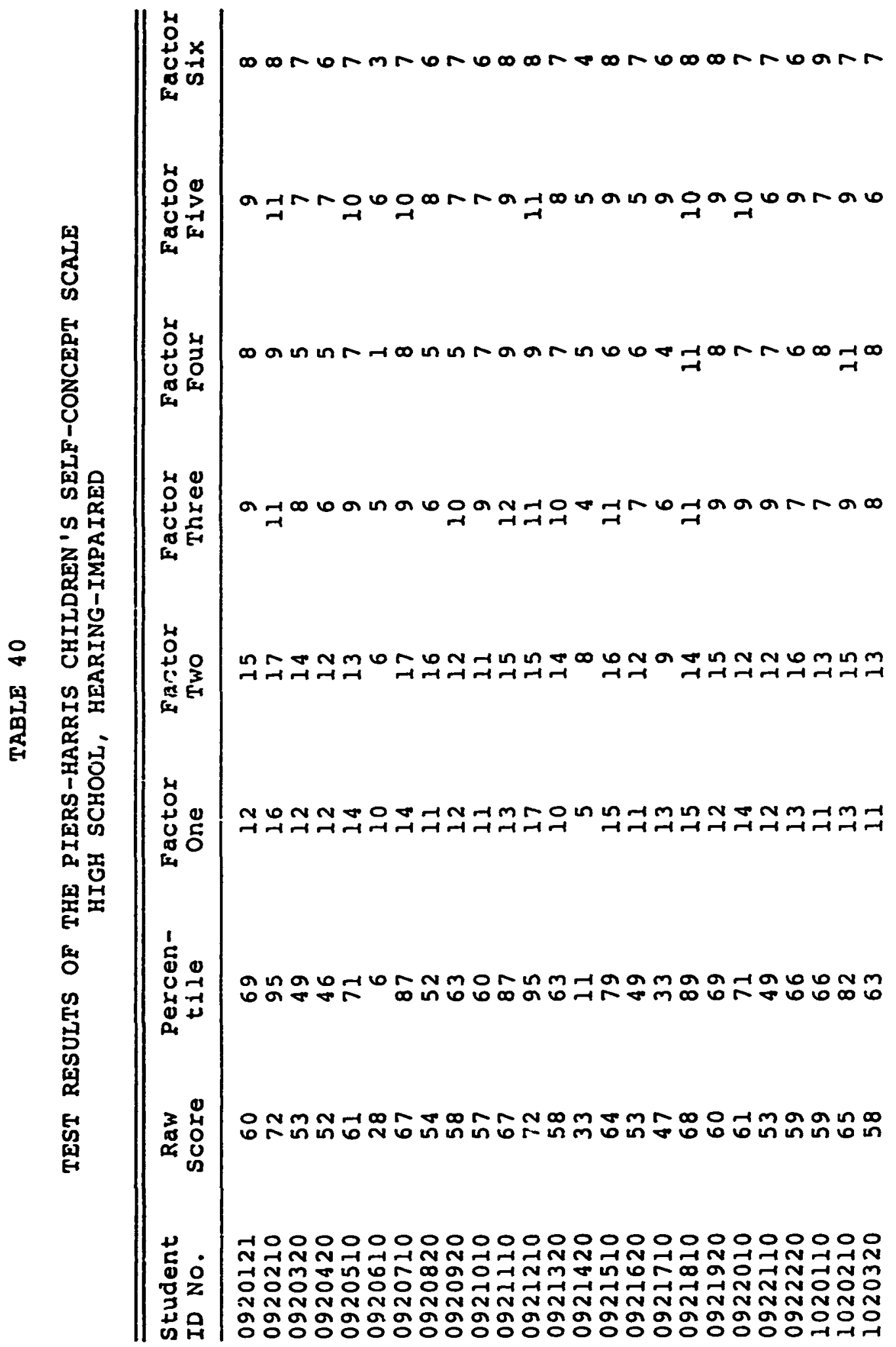




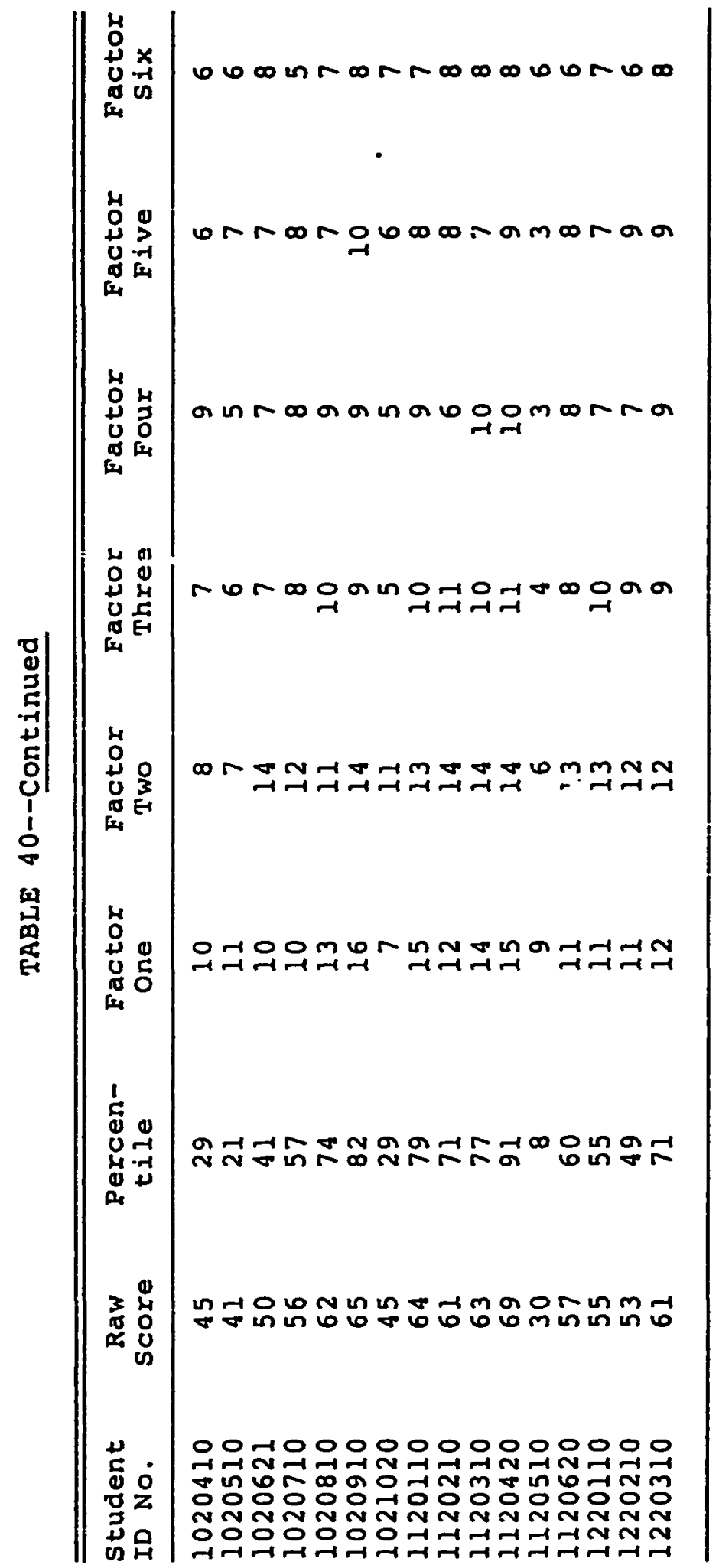


SELECTED BIBLIOGRAPHY

Reproduced with permission of the copyright owner. Further reproduction prohibited without permission. 


\title{
SELECTED BIBLIOGRAPHY
}

\begin{abstract}
Allport, Gordon W. Personality: A Psychological Interpretation. New York: olt, Reinhart, and Winston, Inc., 1937.

Ambrose, Anthony. Stimulation in Early Infancy. New York: Academic Press, Inc., 1969.

Arnold, Magda B., and Gasson, John A. The Human Person: An Approach to and Integral Theory of Personality. New York: Ronald Press Company, 1954.

Ausubel, David P.; Montemayor, Raymond; and Svajian, Pergrouhi. Theory and Problems of Adolescent Development. New York: Grune and Stratton, 1977.

Barreic, Thomas C., and Tinsley, Howard E. A. "Vocational Self-Concept Crystalization and Vocational Indecision." Journal of Counseling Psychoiogy 24 , no. 4 (1977) : $301-307$.
\end{abstract}

Baumrind, Diana. "Parental Control and Parental Love." Children 12, no. 7 (1965):230-245.

Baughman, E. Earl, and Welsh, George Schlager. Personality: A Behavorial Science. Englewood Cliffs, New Jersey: Prentice Hall, Inc., 1962.

Bender, Ruth E. The Conquest of Deafness. Cleveland: Press of Case Western Reserve University, 1970.

Benjamins, John. "Changes in Performance in Relation to Influences upon Self-Concept." Journal of Abnormal Social Psychology 45, no. 5 (1950: 473-80.

Boatner, Maxine Tull. Voice of the Deaf: A Biography of Edward Miner Gallaudet. Washington, D.C.: Public Affairs Press; 1959.

Bolton, Brian. Psychology of Deafness for Rehabilitation Counselors. Baltimore: University Park Press, 1976 . 
Boone, Daniel. "Modification of the Voices of Deaf Children." The Volta Review 68 (November 1968): 686-92.

Briggs, Dorothy Corkville. Your Child's Self-Esteem. New York: Doubleday \& Company, Inc., 1970.

Brookover, Wilbur B.; Erickson, Edsel L.; and Joiner, Lee M. Relationship of Self-Concept to Achievement in High School. Cooperative Research Program of the Office of Education; United States Department of Health, Education and Welfare. Human Learning Research Institute, Michigan State University, East Lansing, Michigan, February, 1967.

Brunschwig, Lily. A Study of Some Personality Aspects of Deaf Children. New York: Teachers College, Columbia University, 1936.

Burgoyne, Peter H. "Concepts of Present Self, Expected Self, and Ideal Self in Vocationa? Preferences and Expectations." Journal of Vocational Behavior 14, no. 2 (1979):134-44.

Buros, Oscar Kirisen. The Seventh Mental Measurement Yearbook. Highland Park, New Jersey: Gryphon Press, 1972.

Campbell, Donald T., and Stanley, Julian C. Experimental and Quaisi-Experimental Designs for Research. Chicago: Rand McNally College Publishing Company, 1963.

Combs, Arthur W.; Avila, Donald L.; and Purkey, William W. Helping Relationships. Boston: Allyn and Bacon, Inc., 1973.

Coopersmith, Stanley. The Antecedents of Self-Esteem. San Francisco: W. H. Freeman and Company, 1967. - "A Method of Determining Types of Self-Esteem." Journal of Abnormal and Social Psychology 58 , no. 4 (1959):87-94.

Cosper, Charles H. "An Oral Adult Speaks: On Activities of Teenage Children." The Volta Review 73 (April $1971): 240-42$.

Gofey, Charles H. Human Nature and the Social Order. Chicago: Charles Scribner's Sons, 1922. 
Croft, John C. "A Look at the Future of a HearingImpaired Child of Today." The Volta Review 76 (February 1974):115-22.

Cunningham, Dean. "Testing Modified Transparancies for Teaching the Deaf with Overhead Projectors." The Volta Review 71 (March 1969):174-81.

Dobson, Russell; Silvertooth, C. Lindel; and Dobson, Judith Shelton. "Comparison of Achievement, Self-Concept, Perceived Environment, and Attendance of Bused and Nonbused White Fifth and SixthGrade Children." The Humanist Educator 15

(March 1977) : 140-47.

Doleman, J.C. Personality Dynamics and Effective Behavior. Chicago: Scott, Freesman and Company, 1960 .

Drever, James. A Dictionary of Psychology. Baltimorc: Penguin Books, Inc., 1952.

Eisen, Marvin, and Montemayor, Raymond. "The Development of Self-Concept from Childhood to Adolescence." Developmental psychology 13, no. 4 (1977):314-19.

Elkind, D. A Sympathetic Understanding of the Child: Six to sixteen. Boston: Allyn and Bacon, 1971.

Erikson, Erik H. Chilahood and Society. New York: W. W. Norton and Company, Inc., 1950. - Identity: Youth and Crisis. New York: W. W. Norton and Company, Inc., 1968.

Ewing, Alexander. New Opportunities for Deaf Children. London: University of London Press, 1961.

Fellendorf, George W. "Guidelines to New Model Preschool Programs." The Volta Review 62 (February 1969): 59-69.

Felkner, Donald W. Building Self-Concepts. Minneapolis, Minnesota: Burgess Publishing Company, 1974.

Ferguson, George A. Statistical Analysis in Pschology and Education. New York: McGraw-Hill Book Company, 1976 .

Finch, Alton C. "Self-Image--F Life Tool Element of Career Education." Business Education Forum 32 (March 1978): 3 . 
Flora, Roslind Reed. "The Effect of Self-Concept upon Adolescents' Communication with Parents." The Journal of School Health 23 (February 1978):56.

Froom, Erich. "Selfishness and Self-Love." Psychiatry 2, no. 5 (January 1939): 213-224.

Freud, Anna, and Burlingham, Dorothy T. War and Children. New York: Ernest Willard, 1943.

Freud, Sigmund. A General Introduction to Psychoanalysis. Garden City, New York: Garden City Publishing Company, 1943.

Frick, Elizabeth. "Adjusting to Integration: Some Dificulties Hearing-Impaired Children Have in Public Schools." The Volta Review 75 (January 1973): $36-46$.

Furth, Hans G. Deafness and Learning. Belmont, California: Wadsworth Publishing Company, Inc., 1973.

Gallaher, James J. "Organization and Special Education." Exceptional Children 34 (March 1968) : 485-91.

Garrison, Wayne M.; Tesch, Stephanie; and DeCaro, Patricia. "An Assessment of Self-Concept Levels among Post-Secondary Deaf Adolescents." American Annals of the Deaf 123 (December 1978):317-26.

Garwood, S. Gray. "Effects of Level of Cognitive Development on Self-Concept Changes in Young Adolescents." U.S. Department of Health, Education and Welfare; National Institute of Education, 1978.

Gergen, Kenneth J. The Concept of Self. New York: Holt, Reinhart, and Winston, Inc., 1971.

Germain, Robert B. "Self-Concept and Self-Esteem Reexamined." Psychology in the Schools 15 (July 1978) : 386-89.

Giangreco, C. Joseph, and Giangreco, Marianne Ranson. The Education of the Hearing-Impaired. Springfield, Illinois: Charles C. Thomas, 1970.

Gordon, Jesse E. Personality and Behavior. New York: MacMillian Company, 1963. 
Greenhaus, Jeffery H. "Self-Esteem as an Influence on Occupational Choice and Occupational Satisfaction." Journal of Vocational Behavior 1, no. 1 (1971) : 75-83.

Habbe, Stephen. Personality Adjustments of Adolescent Boys with Hearing-Impairment. New York: Teachers College, Columbia, University, 1936.

Hamachek, Don E. Encounters with Self. New York: Holt, Rinehart, and Winston, Inc., 1971.

Hansen, James C., and Maynard, Peter E. Youth: SelfConcept and Behavior. Counseling with Youth Series. Edited by Herman Peters. Columbus, Ohio: Merrill, 1974.

Hardy, Richard W., and Cull, John G. Educational and Psychological Aspects of Deafness. Springfield, Illinois: Charles C. Thomas, 1974.

Hare, Charles M. "Dissecting Self-Esteem." Buman Behavior 7, no. 3 (Fall, i977).

Harris, Charles M. "Scholastic Self-Concept in Early and Middle Adolescents." Adolescence 6 (February 1971) : 269-78.

Hnation, Gail, and Reneu, John P. "Evoked Response Audiology." Central Wisconsin Colony and Training School Research Proceedings. Monograph Supplement: Vol. 1, April 1968.

Horney, Karen. Neurosis and Human Growth. New York: Norton, 1950 .

- The Neurotic Personality of Our Time. New York: Norton, 1936.

Houck, Cherry, and Houck, Ernest. "Investigation of the Relationships between Academic Achievement and Self-Concept in Children with Specific Learning Disabilities." Paper presented to the Annual International Convention, Council for Exceptional Children, Chicago, Illinois, April 1976.

Howard, Douglas P.; Stainbeck, Susan B.; and Stainbeck, William. "The Relationship between Self-Concept and Peer Acceptance." Journal of School Health 42 (February 1972): 109-10. 
Howe, Harold, II. "The Nation's Commitment for Education of Handicapped Children." Exceptional Children

34 (March 1968) : 479-84.

Hurlock, Elizabeth B. Adolescent Development. New York: Holt, Rinehart and Winston, Inc., 1967.

James, William. The Principles of Fsychology. New York: Holt, 1890 .

Jersild, Arthur T. The Psychology of Adolescence. New York: MacMillian Ccripany, 1957.

Judd, Larry R., and Smith, Carolyn B. "The Relationship of Age, Educational Classification, Sex, and Grade to Self-Concept and Ideal Self-Concept in a Basic Speech Course. Communication Education 26 (November 1977): 231-38.

Katz, Lee; Mathias, Steve E, III; and Merrill, Edward C., Jr. The Deaf Child in the Public School. Danville, Illinois: Interstate Publishers \& Printers, Inc., 1974.

Katz, Lillian G. "Building Your Child's Self-Esteem." Parents, July 1979, p. 82.

Kelly, George A. A Theory of Personality. New York: The Norton Company, Inc., 1963.

Kennedy, Patricia, et al. "Results of a Follow-up Sociometric Research Study and Sumnary of Longitude and Cross-Sectional Data of Hearing-Impaired Children Enrolled in Regular Classrooms." Paper presented at Annual International Convention, Council for Exceptional Children, Chicago, Illinois, April 1976.

Kennedy, Patricia, and Bruininks, Robert H. "Social Status of Hearing-Impaired Children in Regular Classrooms." Exceptional Children 34 (February 1974) : 336-42.

Kerlinger, Fred N. Foundations of Behavioral Research. New York: Holt, Rinehart, and Winston, Inc., 1973.

Kiester, Dorothy J. Who Am I? The Development of SelfConcept. Durham, North Carolina: Learning Institute of North Carolina, 1973.

Kilpatrick, Irene D. "Mainstreaming the Hearing-Impaired Child: Critical Values." United States Department of Health, Education, and Welfare, May 11 , 1976 . 
Kilpatrick, William. Identity and Intimacy. New York: Dell Publishing Company, Inc., 1975.

Kirk, Samuel A. "The National Advisory Comnittee on Handicapped Children." Exceptional Children 34 (March 1968): 481-84.

Kizzar, Janet, and Hagedorn, Judy. Search for Acceptance: The Adolescent and Self-Esteem. Chicago: Nelson-Hall, 1979 .

Kleinke, Chris L. Self-Perception: The Psychology of Personal Awareness. San Francisco: W. H. Freeman and Company, 1978.

Knox, Laura L., and McConnell, Freeman. "Helping Parents to Help Deaf Infants." Children, SeptemberOctober 1968, p. 67.

Kelly, George A. A Theory of Personality. New York: W. W. Norton and Company, Inc., 1963.

Labenne, Wallace D., and Greene, Bert I. Educational Implications of Self-Concept Theory. Pacific Palisades, California: Goodyear Publishing Company, 1969.

LaPorta, Rita Ann, et al. Mainstreaming Preschoolers: Children with Hearing-Impairment. United States Department of Health, Education and Welfare; Office of Human Development Services, Administration for Children, Youth and Families, 1971.

Leonard, Russel L.; Walsh, W. Bruce; and Osipow, Samuel H. "Self-Esteem, Self-Consistency, and Second Vocational Choice." Journal of Counseling Psychology 20, no. 1 (1973):91-93.

Lerrman, Alan M., and Guifoyle, George R. The Development of Pre-Vocational Behavior in Deaf Adolescents. New York: Feachers College, Columbia University, 1970.

Lewin, Kurt. Principles of Topological Psychology. New York: McGraw-Hill Book Company, 1936.

Liben, Lynn S. Deaf Children: Developmental Perspectives. New York: John Wiley \& Sons, 1978.

London, Harvey, and Exner, John E., Jr. Dimensions of Personality. New York: John Wiley \& Sons, 1978. 
Long, John A. Motor Abilities of Deaf Children. New York: Teachers College, Columbia University, 1932.

Lopez, Elisa M., and Greenhaus, Jeffery H. "Self-Esteem, Race and Job Satisfaction." Journal of Vocational Behavior 13, no. 1 (1978):75-83.

Lugo, James O., and Hershey, Gerald L. Human Development: A Psychology, Biological, and Sociological Approach to the Life Span. New York: MacMillan Publishing Company, Inc., 1979.

Lundholm, Gelge, "Reflection Upon the Nature of the Psychological Self." Psychological Review 47 (1940) : 110-27.

Lydel1, Ruth G. "Adolescent and Adult Self-Esteem as Related to Cultural Values." Adolescence 7 (Spring 1973): 341-48.

Maltz, Maxwell. The magic Power of Self-Image Psychology. Englewood Cliffs, New Jersey: Prentice-Hall, Inc., 1964.

Manaster, Guy J. Adolescent Development and the Life Tasks. Boston: Aliyn and Bacon, Inc., 1977.

Manaster, Guy J.; Saddler, Charles D.; and Wukasch, Linda. "The Ideal Self and Cognitive Development in Adolescence." Adolescence 7, no. 48 (Winter, 1977) : 38-43.

Martin, Edwin W., Jr. "Breakthrough for the Handicapped: Legislative History." Exceptional Children 34 (March, 1970$): 493-503$.

McElroy, Dierde, and Bernstein, H. William. "The Role of Parents in Development of Self-Esteem in a Hearing-Impaired Child." The Volta Review 78 (September 1976) :213-23.

McGee, Donald I. "Critical Variables in the Mainstreaming of Hearing-Impaired Children." Paper presented at the Annual International Convention, Council for Exceptional Children, Chicago, Illinois, April, 1976.

Mead, George H. Mind, Self, and Society. Chicago: University of Chicago Press, 1934. 
Meadow, Kathryn. "Personality and Social Development of a Deaf Person." Psychology of Deafness for Rehabilitation Counselors. Edited by Brian Bolton. Baltimore: University Park Press, 1976.

Miller, John K.: Munson, Harold L.; Gargantile, Carol W.: and Huang, Jerry. "Philosophical Consideration in Maintstreaming the Hearing-Impaired in Occupational Programs: An Empirically Based Discussion of Goals and Objectives." Paper prepared for the 1978 American Educational Research Association, Toronto, Canada, 1978.

Mincinin, Patricia. The Middle Years of Childhood. Monterrey, California: Brooks-Cole Publishing Company, 1977.

Mindel, Eugene D., and McCay, Vernon. They Grow in Silence. Silver Spring, Maryland: National Association of the Deaf, 1971.

Mischel, Theodore. The Self: Psychological and Philosophical Issues. Bristol, England: Western Printing Services Limited, 1977.

Montemayor, Raymond, and Eisen, Marvin. "The Development of Self-Conceptions from Childhood to Adolescense." Development Psychology 13, no. 4 (1959): 314-19.

Moores, Donald F. Educating the Deaf: Psychology, Principles, and Practices. Dallas: Houghton Mifflin Company, 1978 .

Munson, Harold L. Foundations of Developmental Guidance. Boston: Allyn and Bacon, Inc., 1971.

Murphy, Gordon. Personality: A Biosocial Approach to Origins and Structures. New York: Harper and Row Publishers, 1947.

Murray, Ellen, and Wellman, Barry. "Success and SelfConception: The Impact of Academic Grades on the Student Role Identities of Black and White Adolescents." Paper presented at the annual meeting of American Sociological Association, Denver, Colorado, August, 1971.

Muus, Rolf E. Theories of Adolescence. New York: Random House, 1975. 
Myers, Gerald E. Self: An Introduction to Philosophical Psychology. New York: Pegasus, 1969.

Myklebust, Helmer R. "The Deaf Child with Other Handicaps." Annals of the Deaf 103, no. 4 (September 1958) : 496-509.

- The Psychology of Deafness. New York: Grune and Stratton, 1964 .

- Your Deaf Child. Springfield, Illinois: Charles C. Thomas, 1950.

Noblitt, George W. "The Adolescent Experience and Adult Success: A Non-metropolitan Investigation." Paper prepared for the Rural Sociology Section of the Southern Association of Agriculture Scientists, Memphis, Tennessee, February, 1974.

Okun, Morris A., and Sasfy, Joseph H. "Adolescence, the Self-Concept, and Formal Operations." Adolescence 12 (Fall 1977):506-10.

O'Neill, John J. The Hard of Hearing. Englewood Cliffs, New Jersey: Prentice-Hall, 1964.

Oyer, Herbert J., and Frankman, Judith P. The Aural Rehabitation Process. New York: Holt, Rinehart, and Winston, 1975 .

Piers, Ellen V. The Piers-Harris Children's Self-Concept Scale. Nashville, Tennessee: Counselor Recordings and Tests, Research Monograph, 1977.

- The Piers-Harris Children's Self-Concept Scale Manual. Nashville, Tennessee: Counselor Recordings and Tests, 1969.

Protinsky, Howard O. "Eriksonian Ego Identity in Adolescents." Adolescence 10 (February 1975):428-32.

Purkey, William Watson. Self-Concept and School Achievement. Englewood CIiffs, New Jersey: PrenticeHall, Inc., 1970.

Resnick, Harvey; Fauble, Marianne Leeson; and Osipow, Samuel H. "Vocational Crystallization and SelfEsteem in College Students." Journal of Counseling Psychology 17, no. $5(1970): 405-67$. 
Robinson, John P., and Shaver, Phillip R. Measures of Social Psychological Attitudes. Institute of Social Research, University of Michigan, Ann Arbor, Michigan, 1976.

Robinson, Luther D. Sound Minds in a Soundless World. Washington, D.C.: U.S. Department of Health, Education, and Welfare, National Institute of Mental Health, 1973.

Rodda, Michael. The Hearing-Impaired School Leaver. London: University of London Press, Ltd., 1970.

Rogers, Carl R. Client-Centered Therapy: Its Current Practice, Implications and Theory. Boston: Houghton Mifflin Company, 1951.

Rogers, Carl R.; Smith, Monte D.; and Coleman, J. Michael. "Social Comparison in the Classroom: The Relationship between Academic Achievement and Self-Concept." Journal of Educational Psychology 70 , no. 1 (1978):50-57.

Rosenberg, Barbara Strassberg, and Gaier, Eugene L. "The Self-Concept of the Adolescent with Learning Disabilities." Adolescence 12 (Winter 1977):301-308.

Ross, Mark, and Giolæs, Thomas G. Auditory Management of Hearing Children. Balitmore: University Park Press, 1978.

Schiffler, Nancy; Lynch-Sauer, Judith; and Naralman, Lorraine. "Relationship between Self-Concept and Classroom Behavior in Two Informal Elementary Classrooms." Journal of Educational Psychology 69 (August 1977):349-59.

Schipper, Javiä James. Self-Concept Differences between Early, Late, and Non-Boarding Missionary Children. Unpublished dissertation, Rosemead, Ealifornia, 1977.

Schwarzrock, Shirley, and Wrenn, C. Gilbert. Do I Know the "Me" Others See? Circle Pines, Minnesota: American Guidance Services, Inc., 1973.

Shavelson, Richard J.; Huber, Judith J.; and Stanton, George C. "Self-Concept: Validation of Construct Interpretations." Review of Educational Research 46 (Summer 1976): 407-41. 
Shephard, Lorria A. "Self-Acceptance: The Evaluative Component of the Self-Concept." American Educational Research Journal 16 (Spring 1979): 139-60.

Shore, Irwin. "The Deaf Child from 2-5: Evaluation and Educational Planning." In Report on the Proceedings of the International Congress of the Education of the Deaf, Washington, D.C.: U.S. Government Printing office, 1964, pp. 596-99.

Sievert, Norman $w$. "The Ro'e of the Self-Concept in Determining an Adolescent's Occupational Choice." Journal of Industrial Education 9, no. 3 (Spring 1972):58-67.

Silver, Nancy. "Recommendations for a Measure of SelfConcept." Unpublished paper, October 19, 1965, from ERIC Files.

Simmons, Audrey Ann. "Language Growth for the Prenursery Deaf Child." The Volta Review 8 (March 1966): 201-205.

Simmons-Martin, Audrey, and Calvert, Donald R. ParentInfant Intervention. New York: Grune Strattor, Inc., 1979.

Skolnick, Arlene. Rethinking Childhood Perspectives on Development and Society. Boston, Little, Brown, and Company, 1976.

Snygg, David, and Combs, Arthur $W$. Individual Behavior. New York: Harper and Row Publishers, 1949.

- "Phenomenal Self." Theories of Personality. Edited by Hall and Lindzey. New York: John Wiley and Sons, Inc., 1963.

Spitz, Renne A. A Genetic Field Theory of Ego Formation. New York: International Universities Press, Inc., 1959 .

Stern, Daniel. The First Relationship: Mother and Child. Cambridge, Massachusetts: Harvard University Press, 1977.

Strang, Louise: Smith, Monte D.; and Rogers, Carl M. "Social Comparison, Multiple Reference Groups, and the Self-Concepts of Academically Handicapped Children before and after Mainstreaming." Journal of Educational Psychology 70 , no. 4 (1978): $\overline{487-97 .}$ 
Streng, Alice, et al. Hearing Therapy for Children. New York: Grune and Stratton, 1958.

Sullivan, Harry Stack. Conceptions in Modern Psychiatry. Washington, D.C.: Alanson White Psychiatric Foundation, 1947.

- The Interpersonal Theory of Psychiatry. New York: Nort.un Press, 1953.

Symonds, Phillip The Ego and Self. New York: AppletonCentury-irofts, 1951 .

Taub, Marvin. "jelf-Concepts of Parents and Children." Home Economics Research Journal 3 (December 1974): 30-36.

Thomas, M. Angele. "Preschool." A Report on the Proceedings of the International Congress on the Education of the Deaf. Washington, D.C.: U.S. Government Printing office, 1964, pp. 483-93.

Tracy, Mrs. Spencer. "Most Productive Environments for Mentally Retarded Individuals." Journal of Research and Development in Education 13, no 4 (1980):206-9.

Upshall, C. C. Day Schools Versus Institutions for the Deaf. New York: Teachers College, Columbia University, 1929.

Van Pelt, Nancy. The Complete Parent. Nashville, Tennessee: Southern Publishing Association, 1976.

Vogel, Jerry. "Learning and Self-Esteem: You Can't Have One without the Other." Learning 2 (March 1974): 68-72.

Voice, Elanor. "Speech in the Preschool for the Deaf." The Volta Review 60 (November 1958): 478-81.

Wagner, Maurice E. The Sensation of Being Somebody. Grand Rapids, Michigan: Zondervan Publishing House, 1975.

Webster, Murray, and Sobieszek, Barbara. Sources of Self-Evaluation. New York: John Wiley and Sons, 1974 .

Weinstein, Grace W. "Nursey School with a Difference." Parent's Magazine, November 1968, pp. 43-48. 
Welles, Henry Hunter. The Measurement of Certain Aspects of Personality among Hard-of-Hearing Adults. New York: Teachers College, Columbia University, 1932.

Wilkens, William H. R. The Youth Years. Valley Forge, Pennsylvania: Judson Press, 1967.

Woolsey, Raymond H. Planning the Ideal Home. Washington, D.C.: Review and Herald Publishing Association, 1975 .

Wylie, Ruth C. The Self-Concept. A Critical Survey of Pertinent Research Literature. Lincoln, Nebraska: University of Nebraska Press. 1961.

- The Self-Concept. Lincoln Nebraska: University of Nebraska Press, 1974.

Yale, Caroline A. Years of Building. New York: Dial Press, 1931 .

Yamamoto, Kaoru. The Child and His Image. Self-Concept in the Early Years. New York: Houghton Mifflin Company, 1972 . 
VITA

Name: Wayne $\mathrm{K}$. Wright

Date and Place of Birth: May 23, 1937; Sheridan, Indiana Undergraduate and Graduate Schools Attended:

Emmaruel Missionary College, Berrien Springs, Michigan

Andrews University, Berrien Springs, Michigan

Indiana University at South Bend, South Bend, Indiana

Degrees Awarded:

1959 Bachelor of Arts, Emmanuel Missionary

College

1961 Master of Arts in Teaching, Andrews

1975 Marter of Arts Andrews University

1981 Doctor of Education, Andrews University

Experience :

1960-63 Sixth Grade Teacher, Fairplain Public

Schools, Benton Harbor, Michigan

1963-67 Junior High School Teacher, Fairplain

$F:=b l i c$ Schools, Benton Harbor, Michigan

1967-76 High School Teacher, Benton Harbor High

School, Benton Harbor, Michigan

1966-76 Teacher, Benton Harbor Summer High

School, Benton Harbor, Michigan

1966-71 Teacher, Benton Harbor Evening High

School, Benton Harbor, Michigan

1971-72 Assistant Director, Benton Harbor Evening High School, Benton Haroor, Michigan 
1975-77 Director, Berrien Springs Evening High School, Berrien Springs, Michigan

1976-81 Counselor, Berrien Springs High School, Berrien Springs, Michigan 